Published in final edited form as:

Cochrane Database Syst Rev. ; 12: CD003968. doi:10.1002/14651858.CD003968.pub3.

\title{
Psychological therapies for the management of chronic and recurrent pain in children and adolescents
}

\author{
Christopher Eccleston ${ }^{1}$, Tonya M Palermo ${ }^{2}$, Amanda C de C Williams ${ }^{3}$, Amy \\ Lewandowski ${ }^{4}$, Stephen Morley ${ }^{5}$, Emma Fisher ${ }^{6}$, and Emily Law ${ }^{7}$ \\ ${ }^{1}$ Centre for Pain Research, The University of Bath, Bath, UK \\ ${ }^{2}$ Anesthesiology and Pain Medicine, University of Washington, Seattle, Washington, USA \\ ${ }^{3}$ Research Department of Clinical, Educational \& Health Psychology, University College London, \\ London, UK \\ ${ }^{4}$ Division of Psychology, Children's Hospital Boston, Boston, MA, USA \\ ${ }^{5}$ Leeds Institute of Health Sciences, University of Leeds, Leeds, UK \\ ${ }^{6}$ Department of Health, University of Bath, Bath, UK \\ ${ }^{7}$ Child Health, Behaviour \& Development, Seattle Children's Research Institute, Seattle, WA, USA
}

\begin{abstract}
Background-Chronic pain affects many children, who report severe pain, distressed mood, and disability. Psychological therapies are emerging as effective interventions to treat children with chronic or recurrent pain. This update adds recently published randomised controlled trials (RCTs) to the review published in 2009.
\end{abstract}

Objectives-To assess the effectiveness of psychological therapies, principally cognitive behavioural therapy and behavioural therapy, for reducing pain, disability, and improving mood in children and adolescents with recurrent, episodic, or persistent pain. We also assessed the risk of bias and methodological quality of the included studies.

Search methods-Searches were undertaken of MEDLINE, EMBASE, and PsycLIT. We searched for RCTs in references of all identified studies, meta-analyses and reviews. Date of most recent search: March 2012.

Copyright $(2012$ The Cochrane Collaboration. Published by John Wiley \& Sons, Ltd.

Contact address: Christopher Eccleston, Centre for Pain Research, The University of Bath, Claverton Down, Bath, BA2 7AY, UK. papas@bath.ac.uk. c.eccleston@bath.ac.uk.

CONTRIBUTIONS OF AUTHORS

Christopher Eccleston oversaw the project and contributed to the design, analysis and authoring of the text and is responsible for any future update of this review.

Amy Lewandowski, Emma Fisher, Emily Law, Stephen Morley, Tonya Palermo, and Amanda Williams, all contributed to the design, analysis and authoring of the text.

DECLARATIONS OF INTEREST

None known.

DIFFERENCES BETWEEN PROTOCOL AND REVIEW

1. In Eccleston 2009 CENTRAL database was searched to recruit studies. In this review we judged this to have a low yield and any potential studies could be identified through PsychINFO, EMBASE, and MEDLINE.

2. In this update of the review, there is more clarity around how treatment and control groups were combined.

3. In Eccleston 2009 Odds Ratios and Risk Ratios were reported for dichotomous outcomes. In this review we only report Risk Ratios. 
Selection criteria-RCTs with at least 10 participants in each arm post-treatment comparing psychological therapies with active treatment were eligible for inclusion (waiting list or standard medical care) for children or adolescents with episodic, recurrent or persistent pain.

Data collection and analysis-All included studies were analysed and the quality of the studies recorded. All treatments were combined into one class: psychological treatments; headache and non-headache outcomes were separately analysed on three outcomes: pain, disability, and mood. Data were extracted at two time points; post-treatment (immediately or the earliest data available following end of treatment) and at follow-up (at least three months after the posttreatment assessment point, but not more than 12 months).

Main results-Eight studies were added in this update of the review, giving a total of 37 studies. The total number of participants completing treatments was 1938. Twenty-one studies addressed treatments for headache (including migraine); seven for abdominal pain; four included mixed pain conditions including headache pain, two for fibromyalgia, two for pain associated with sickle cell disease, and one for juvenile idiopathic arthritis. Analyses revealed five significant effects. Pain was found to improve for headache and non-headache groups at post-treatment, and for the headache group at follow-up. Mood significantly improved for the headache group at follow-up, although, this should be interpreted with caution as there were only two small studies entered into the analysis. Finally, disability significantly improved in the non-headache group at posttreatment. There were no other significant effects.

Authors' conclusions-Psychological treatments are effective in reducing pain intensity for children and adolescents ( $<18$ years) with headache and benefits from therapy appear to be maintained. Psychological treatments also improve pain and disability for children with nonheadache pain. There is limited evidence available to estimate the effects of psychological therapies on mood for children and adolescents with headache and non-headache pain. There is also limited evidence to estimate the effects on disability in children with headache. These conclusions replicate and add to those of the previous review which found psychological therapies were effective in reducing pain intensity for children with headache and non-headache pain conditions, and these effects were maintained at follow-up.

\section{Medical Subject Headings (MeSH)}

*Pain Management; Abdominal Pain [therapy]; Chronic Disease; Cognitive Therapy; Fibromyalgia [therapy]; Headache [therapy]; Hemoglobin SC Disease [complications]; Mood Disorders [therapy]; Pain [psychology]; Psychotherapy [*methods]; Randomized Controlled Trials as Topic; Recurrence

\section{MeSH check words}

Adolescent; Child; Humans

\section{PLAIN LANGUAGE SUMMARY}

\section{Psychological therapies for the management of chronic and recurrent pain in children and adolescents}

Psychological therapies (relaxation, hypnosis, coping skills training, biofeedback, cognitive behavioural therapy) are treatments that may help people manage pain and its disabling consequences. For children and adolescents there is good evidence that both relaxation and cognitive behavioural therapy (treatment that helps people test and revise their thoughts and actions) are effective in reducing the severity and frequency of pain in chronic headache, recurrent abdominal pain, fibromyalgia, sickle cell disease, and juvenile idiopathic arthritis immediately after treatment is delivered. Psychological therapies also have a lasting effect 
for improving mood and reducing pain for chronic headache. Forty-nine per cent of children who received psychological therapies reported less pain compared with $17 \%$ of children who did not receive a psychological therapy. Disability is improved immediately after treatment for many pain conditions (not chronic headache) which helps young people to participate in important daily activities. More studies are needed to understand whether psychological therapies can improve mood and have more lasting effects on pain and disability in other groups of young people who have chronic pain.

\section{BACKGROUND}

\section{Description of the condition}

This review is an update of a previously published review in The Cochrane Database of Systematic Reviews (Eccleston 2009) on 'Psychological therapies for the management of chronic and recurrent pain in children and adolescents'. Chronic and recurrent pain (pain lasting more than three months) is a common problem in young people. Recent epidemiology gives the prevalence at $15 \%$ to $30 \%$, with $8 \%$ of children described as having severe and frequent pain (Perquin 2000; Perquin 2001; Stanford 2008). The most common location for pain is in the head, abdomen, and limbs (Perquin 2000). All types of chronic and recurrent pain are more commonly reported by girls, and peak in incidence at ages 14 to 15 years (Stanford 2008). Young people report pain to be distressing and interfering, and in some cases this can be severely debilitating, affecting all aspects of a child's life (Bursch 1998; Palermo 2000) and the lives of their parents and family members (Walker 1989; Palermo 2005). The deleterious effects of untreated pain in childhood can also extend to adulthood (Fearon 2001).

\section{Description of the intervention}

There is a broad family of treatments included in the general term "psychological". In essence, treatments have been developed that are specifically designed to alter psychological processes thought to underlie or significantly contribute to pain, distress, and/or disability. The design of psychological treatments is normally informed by specific theories of the etiology of human behaviour, or have developed pragmatically through observation and study of response to intervention. Behavioural and cognitive treatments designed to ameliorate pain, distress and disability were first introduced with adults over 40 years ago and have become well established (Fordyce 1968; Keefe 2004). A companion review of psychological treatments for the management of chronic pain in adults is also published (Eccleston 2009a).

\section{How the intervention might work}

In paediatric practice, however, the treatments have a shorter history and different therapeutic aims and components than those used with adults. In general, psychological treatments have aimed to control pain and modify situational, emotional, familial, and behavioural factors that play a role in pain or related consequences (e.g., McGrath 1990). A variety of intervention strategies have been designed to reduce pain sensations, increase comfort, and/ or reduce associated disability and dysfunction in children with pain conditions. Behavioural strategies include relaxation training, biofeedback, and behavioural management programs (e.g., teaching parents operant strategies to reinforce adaptive behaviours such as school attendance). Cognitive strategies include hypnosis, stress management, guided imagery, and cognitive coping skills (Palermo 2012).

Cognitive behavioural programs incorporate elements of both behavioural and cognitive strategies. Given that headache and abdominal pain are the most common types of recurrent pain in children, most of the treatment literature has focused on these two populations. By 
far the most commonly described treatment is relaxation training and/or biofeedback for headache, and recommendations have been made to offer psychological treatment as a matter of routine care for children with headaches (Masek 1999). In an effort to enhance the efficiency of psychological treatments for children with headache, more recent treatment developments have compared different elements of relaxation training and biofeedback with a variation in treatment formats (individual and group), treatment dose, and treatment setting (clinic, school, and home).

Psychological therapies have also been developed to treat children with non-headache chronic and recurrent pain including children with abdominal, musculoskeletal, and diseaserelated pain. Multidisciplinary pain treatment programs for children have recently become a standard of care (McGrath 1999a), and now many specialised pain clinics are available for children with chronic or recurrent pain, which may involve outpatient care or intensive inpatient rehabilitation. Such programs offer physical rehabilitation, psychological treatment, and medical strategies, and aim to restore function rather than provide pain relief. There is evidence from case series and uncontrolled studies for the effectiveness of multidisciplinary treatment with psychological therapy for paediatric chronic and recurrent pain (Eccleston 2003b).

\section{Why it is important to do this review}

Several reviews have documented the effectiveness of psychological therapies for children with headache, abdominal, and disease-related pain (Janicke 1999; Kibby 1998; Holden 1999; Huertas-Ceballos 2008; Walco 1999; Weydert 2003). Three reviews have used data pooling techniques for studies of children with headache (Eccleston 2009; Hermann 1995; Trautmann 2006). In their review of paediatric migraine Hermann 1995 found that biofeedback and muscle relaxation are more effective than placebo treatments and prophylactic drug treatments in controlling headache. In the previous published Cochrane review (Eccleston 2009), we found that psychological treatments were effective in reducing pain intensity in youths with headache. Trautmann 2006 conducted a meta-analysis of psychological treatment for recurrent headache in children finding small effect sizes across three headache variables: frequency, duration, and intensity, although reduction in pain intensity at post-treatment was a statistically significant effect. A large binomial effect size of $50 \%$ or greater reduction in headache symptoms was reported.

The previous Cochrane review (Eccleston 2009) is now out of date (Shojania 2007). Developments in paediatric psychology have led to new populations of children being treated. The aim of this review is to further update the published evidence on the efficacy of psychological treatments for chronic and recurrent pain in children and adolescents in outcomes with chronic, non-headache, pain.

\section{OBJECTIVES}

- The primary objective of this update review was to determine the effectiveness of psychological therapy for chronic and recurrent pain in children and adolescents compared with other psychological therapies, active treatment, waiting list, or medical care on clinical outcomes of pain severity, mood, and disability.

- The secondary objective was to describe the methodological quality of the studies. 


\section{METHODS}

\section{Criteria for considering studies for this review}

Types of studies-Randomised controlled trials (RCTs) comparing a credible psychological treatment, or a compound treatment with credible primary psychological content, active treatment, treatment as usual, or waiting list control, in paediatric chronic or recurrent pain. Content was judged credible if it referred to a scientific theory of psychological action. Studies were excluded if the pain was associated with a malignant lifethreatening disease.

Studies were included if they:

- were available as a full publication or report of a RCT;

- had a design that placed a psychological treatment as an active treatment of primary interest;

- had a psychological treatment with definable psychotherapeutic content (although not necessarily delivered by someone with psychological qualifications);

- were published (or electronically pre-published) in a peer-reviewed scientific journal;

- were with participants reporting chronic (i.e., three months duration of pain) or recurrent (i.e., episodic) pain; and

- had 10 or more participants in each treatment arm at the end-of-treatment assessment.

Types of participants-Children and adolescents ( $<18$ years) reporting persistent, recurrent or episodic pain in any body site, not associated with cancer or similar life threatening malignant disease.

Types of interventions-Studies were included if at least one trial arm consisted of a psychological intervention, and a comparator arm used, active treatment, treatment as usual, or waiting list control.

\section{Types of outcome measures-}

- Data were collected on descriptive characteristics of patients and characteristics of the treatments, including treatment setting and amount of treatment time.

- All measurement instruments reported in each study were assessed and recorded. The most appropriate measurement instruments for the three domains of pain, (physical) disability, and mood were selected.

- Any mention of adverse events was also recorded.

\section{Search methods for identification of studies}

Electronic searches-Randomised controlled trials (RCTs) of any psychological therapy for paediatric chronic or recurrent pain were identified by searching MEDLINE, EMBASE and PsycINFO from their inception to March 2012. The Cochrane Central Register of Controlled Trials (CENTRAL) was searched in the previous versions of this review (Eccleston 2003a; Eccleston 2009). However, for this update of the review it was agreed by all authors that the sensitivity of CENTRAL for pain trials was low and that all updated trials could be identified through the alternative databases and by contacting study authors 
for further trials. Three separate searches have been undertaken. The first search was undertaken from inception of the abstracting services to the end of 1999 (Eccleston 2003a), the second searched databases from 1999 to 2008 (Eccleston 2009), and the third searched databases from 2008 to March 2012.

\section{Data collection and analysis}

Selection of studies-The selection of included studies was made using the following criteria; the study had to be RCT in design and published in a peer-reviewed journal, include children ( $<18$ years of age) who have chronic pain (non-malignant), include a psychological intervention as an active treatment, and have $>10$ participants in each arm at post-treatment. Psychological interventions were considered for inclusion if they had credible, recognisable psychological/psychotherapeutic content and were specifically designed to change the child's behaviour, cognition, and/or outcomes. There were no additional criteria (regarding sample size or other) added for the purposes of this update, therefore, the trials used in the previous systematic review and meta-analysis (Eccleston 2009) were considered automatically eligible and included.

Data extraction and management-Data were extracted on details relating to the design of the study, the participants, primary diagnosis, method of treatment, outcome measurement tools used, and outcome data for computation of effect sizes. When data were missing on primary outcomes of interest, we contacted trial authors via email to obtain data necessary for effect size calculations. Data suitable for pooling were entered into RevMan 5.1 .

Assessment of risk of bias in included studies-The risk of bias was measured using the recommended Cochrane 'Risk of bias' tool (Higgins 2011). We selected five categories from this tool; random sequence generation (selection bias), allocation concealment (selection bias), blinding of outcome assessment (detection bias), incomplete outcome data (attrition bias), and selective reporting (reporting bias). Two categories were excluded for the purposes of this review as they were deemed redundant because of the nature of delivering or receiving a psychological intervention. The categories were 'blinding (performance bias and detection bias)' and 'blinding participants and personnel'.

Judgements were made on the categories using the following rules. Random sequence generation judgements were based on whether authors gave a convincing method of randomisation. Allocation concealment bias judgements were based on whether there were convincing methods used for random allocation to take place. Participants being stratified by age or gender were not deemed as biased. Blinding of outcome assessment was judged on whether the measures were taken by a third party who was blind to the treatment condition. Incomplete outcome data bias judgements were based on whether attrition was fully reported. Authors had to report attrition at each measurement time point (post-treatment and follow-up), and state whether there were any significant differences between completers and non-completers. Finally, selective reporting bias was judged on whether data could be fully extracted for analyses in this review. If authors provided data when requested, this category would be marked as 'low bias'.

Assessment of quality of included studies-A quality rating scale designed specifically for studies of psychological treatments in chronic pain was applied (Yates 2005). All papers were scored by two of the review authors and consensus reached after initial comparison of ratings. Interrater reliability was calculated. The quality rating scale provides an overall total quality score (zero to 35 ) consisting of two subscales: a treatment quality scale (zero to nine) covering stated rationale for treatment, manualisation, therapist training, and patient engagement; and a design and methods scale (zero to 26) covering 
inclusion/exclusion criteria, attrition, sample description, minimisation of bias (randomisation method, allocation bias, blinding of assessment, and equality of treatment expectations), selection of outcomes, length of follow-up, analyses, and choice of control. This comprehensive quality assessment method was used in place of the single item of allocation bias.

Measures of treatment effect-All treatments labelled as psychological were combined in the following meta-analyses, and designated "Treatment". Similarly, all control conditions were combined and designated "Control". Where more than one intervention or control group was reported the intervention or control arms were combined to create a single pair-wise comparison in accordance with the Cochrane Handbook for Systematic Reviews of Interventions (Higgins 2011). The studies were divided into two groups. The first group was labelled "headache" and the second group was labelled "non-headache". Two assessment points were also selected: post-treatment and follow-up. Post-treatment is the assessment point occurring soonest following treatment (often after a delay of several weeks to allow for recording of episodic pain), and follow-up is the assessment point at least three months after the post-treatment assessment point, but not more than 12 months, and the longer time point was selected if there were two follow-up assessments within this time frame. Therefore, four separate comparisons were designed comprising two forms of comparator (Treatment, Control) and two assessment time points (post-treatment and follow-up). They were labelled as follows.

1. Treatment versus Control (headache) post-treatment.

2. Treatment versus Control (headache) follow-up.

3. Treatment versus Control (non-headache) post-treatment.

4. Treatment versus Control (non-headache) follow-up.

Multiple measurement tools were typically used in each study. For each comparison, three outcomes were identified and labelled "Pain", "Disability", and "Mood". From each trial we selected the measure considered most appropriate for each of the three outcomes. To guide the choice of outcome measure, we applied two rules. First, if an outcome measure was established and occurred frequently among studies it was selected over more novel instruments. Second, given a choice between single item and multi-item self-report tools, multi-item tools were chosen on the basis of inferred increased reliability. Studies did not necessarily report data in all three outcomes. For headache treatments, the data for pain outcomes were dichotomous so relative ratios or risk ratios (RR) were used, and we calculated numbers-needed-to-treat-to-benefit (NNTBs). For disability and mood outcomes, continuous data were used. Continuous data were used for pain, disability, and mood for non-headache studies. Effect sizes can be interpreted as follows; small $=0.2$, medium $=0.5$, large $=0.8$ (Cohen 1992).

Data synthesis-For dichotomous outcomes, such as achieved (or failed to achieve) $50 \%$ reduction in pain, we calculated the odds ratio (OR) using $95 \%$ confidence intervals $(\mathrm{CI})$ and a random-effects model. For ease of interpretation, the risk ratio (RR), and NNTB are also reported. For continuous outcomes (such as rating scales) we calculated the standardized mean differences using 95\% CI and a random-effects model. The heterogeneity of the findings is also reported.

\section{RESULTS}

\section{Description of studies}

See: Characteristics of included studies; Characteristics of excluded studies. 
See: Characteristics of included studies; Characteristics of excluded studies.

\section{Results of the search}

Three separate searches have been undertaken. The first search was undertaken from inception of the abstracting services to the end of 1999 (Eccleston 2003a). This yielded 3715 abstracts, of which 123 were read in full, identifying 18 RCTs. The second search, which updated the original review, was undertaken focusing on the 10 years since the previous search, overlapping by one year; from 1999 to 2008 and was later published (Eccleston 2009). This yielded 1319 abstracts, of which 45 papers were read in full, identifying a further 16 RCTs, giving a total set of 34 . However, five studies were later excluded because they did not meet the minimum criteria of 10 participants in each arm, therefore, leaving 29 studies. The third, which searched databases from 2008 to March 2012 yielded 851 abstracts, of which 25 papers were read in full, and eight further RCTs were included in the review, giving a total of 37 RCTs (Abram 2007; Alfven 2007; Barakat 2010; Barry 1997; Bussone 1998; Connelly 2006; Duarte 2006; Fichtel 2001; Gil 1997; Griffiths 1996; Hicks 2006; Humphreys 2000; Kashikar-Zuck 2005; Kashikar-Zuck 2012; Kroener-Herwig 2002; Labbe 1984; Labbe 1995; Larsson 1987a; Larsson 1987b; Larsson 1990; Larsson 1996; Levy 2010; Palermo 2009; McGrath 1988; McGrath 1992; Osterhaus 1997; Passchier 1990; Richter 1986;Robins 2005; Sanders 1994; Sartory 1998; Scharff 2002; Stinson 2010; Trautmann 2010; van Tilburg 2009; Vlieger 2007; Wicksell 2009). Nine further studies did not meet the inclusion criteria and were excluded (Fentress 1986; Kroener-Herwig 1998; Larsson 1986; Olness 1987; Sanders 1989; Trautmann 2008; Vlieger 2012; Weydert 2006; Youssef 2009).

\section{Included studies}

Of the 37 included studies, eight are new to this update (Barakat 2010; Kashikar-Zuck 2012; Levy 2010; Palermo 2009; Stinson 2010; Trautmann 2010; van Tilburg 2009; Wicksell 2009). The total number of participants completing treatments was 1938,506 more than the previous published analyses. Of the 37 studies, one had four treatment arms, 11 had three arms, and 25 had two arms. The mean number of participants per study at the end of treatment was $52(\mathrm{sd}=34)$. Girls outnumbered boys in 26 studies, and boys outnumbered girls in nine, (65\% girls, range 22 to $100 \%$ ). Age was reported in 35 studies (mean $=11.6$ years, $s d=4.1$ years). Only 16 studies reported the duration of pain, with a mean of 3.8 years.

Participants were recruited from a range of healthcare settings and other sources. Nineteen studies recruited from hospital or clinic settings, four from schools, six from direct advertisement, one study recruited from hospital/clinics and schools, two studies recruited from hospitals and direct advertisements, and five did not report their source. There were 21 studies of treatments for children with headache (including migraine). Of the remainder, seven were for abdominal pain (Alfven 2007; Duarte 2006; Humphreys 2000; Levy 2010; Robins 2005; Sanders 1994; van Tilburg 2009), and one study treated participants with either a primary diagnosis of abdominal pain or a primary diagnosis of irritable bowel syndrome (Vlieger 2007). Two studies treated children with fibromyalgia (Kashikar-Zuck 2005; Kashikar-Zuck 2012), two were for the treatment of pain associated with sickle cell disease (Barakat 2010; Gil 1997) and a further three studies included mixed pain conditions including headache and non-headache pain (Hicks 2006; Palermo 2009; Wicksell 2009) and so were included in both analyses where appropriate. Five study authors provided additional data upon request.

Treatment arms were classified on the basis of their content and of the label given by the study authors. The interventions were categorised into two broad groups. The first is best 
described as behavioural, typically relaxation based, with or without biofeedback, and including autogenic or hypnotherapeutic content (Bussone 1998; Fichtel 2001; Labbe 1984; Labbe 1995; Larsson 1987a; Larsson 1987b; Larsson 1990; Larsson 1996; McGrath 1988; McGrath 1992; Passchier 1990; Vlieger 2007). The second is best described as cognitive behavioural therapy, including cognitive coping, coping skills training, and parent operant strategies (Abram 2007; Alfven 2007; Barakat 2010; Barry 1997; Connelly 2006; Duarte 2006; Gil 1997; Griffiths 1996; Hicks 2006; Humphreys 2000; Kashikar-Zuck 2005; Kashikar-Zuck 2012; Kroener-Herwig 2002; Levy 2010; McGrath 1992; Osterhaus 1997; Palermo 2009; Richter 1986; Robins 2005; Sanders 1994; Sartory 1998; Scharff 2002; Stinson 2010; Trautmann 2010; van Tilburg 2009; Wicksell 2009). Different control conditions were employed that were categorised into either active control (e.g. education, $\mathrm{n}$ $=19)$ or wait-list/treatment as usual control $(n=18)$. Ten studies reported post-treatment data only; five studies reported follow-up of three months or less and therefore were not included in analyses. Fifteen studies reported follow-up data between three months and a year. Thirty studies reported the treatment length which was typically short in duration ( $\mathrm{M}=$ 5.3 hours for headache studies, $M=3.5$ hours for non-headache studies, Table 1). Seven studies did not report on the duration of treatment (Alfven 2007; Connelly 2006; Hicks 2006; Humphreys 2000; Kashikar-Zuck 2005; Sartory 1998; Trautmann 2010).

Treatment delivery varied between studies (Table 1). Eighteen studies delivered treatment in a clinic, eight studies delivered treatment at home, of which five used an internet- or computer-based delivery, three were based either in a clinic or at home, so exposure to treatment was uncontrolled. A further three were based in schools, and five were unknown. Home maintenance or practice of treatment was a common and important feature of many studies, but overall treatment exposure including home practice was not reported. Supervised treatment or the introduction of treatment in self-delivery conditions was, however, commonly reported.

\section{Excluded studies}

Nine studies were excluded, of which four are new to this update (Trautmann 2008; Vlieger 2012; Weydert 2006; Youssef 2009). Seven had fewer than 10 participants in a treatment arm at the end of treatment (Fentress 1986; Kroener-Herwig 1998; Larsson 1986; Sanders 1989; Trautmann 2008; Weydert 2006; Youssef 2009), one study was judged to have insufficient psychological content in the treatment (Olness 1987), and one study reported only follow-up data of more than one year (Vlieger 2012).

\section{Risk of bias in included studies}

All included studies were rated for risk of bias on five categories; random sequence generation (selection bias), allocation concealment (selection bias), blinding of outcome assessment (detection bias), incomplete outcome data (attrition bias), and selective reporting (reporting bias) (Figure 1; Figure 2). Thirteen studies were scored as low risk of bias and gave a convincing method of randomisation, a further 24 studies were judged unclear on random sequence generation as they did not provide an adequate method of randomisation. There were none that were scored as having high risk of bias. There were four studies that were judged to have a low risk of bias and gave a convincing method for the allocation, 22 studies that were unclear and 11 studies that had a high risk of bias. Six studies used a third person who was blinded to the group allocation when taking measurements, 31 studies did not report this and so were unclear. Fifteen studies reported attrition fully, reporting that there was no significant difference between completers and non-completers. Seventeen studies only partially reported attrition and so were judged to be unclear and five studies did not report attrition so were judged to have a high risk of bias. Twenty-two studies reported 
data fully that could be extracted and used in analyses; 15 studies did not provide full extractable data and were judged to have high risk of bias for selective reporting.

\section{Assessment of quality in included studies}

All 37 studies were rated for their quality. For the previously included 29 studies, the quality was rated by two review authors blind to each other's ratings. Intraclass correlation coefficients (absolute agreement) for the two raters on each of the three quality scores (trial quality, study design, and total) ranged from 0.87 for trial quality, 0.89 for study design, and 0.90 for total quality. The quality for the updated eight studies was also rated by two review authors (EF, EL) and disagreements were arbitrated by a third review author (CE) meaning that agreement was met on all items. For the 37 included studies, the mean overall quality of the studies was $20.3(\mathrm{sd}=5.6$, range $=11$ to 32$)$. The mean design quality score was 14.4 ( $\mathrm{sd}=4.1$, range $=8$ to 23$)$ and the mean treatment quality score was $5.9(\mathrm{sd}=2.0$, range $=2$ to 9). The 'Risk of bias' tables' graphics show the overall total quality rating, and summary scores for the quality of the treatment and the quality of the design (Figure 1; Figure 2). A Spearman's correlation was conducted to investigate the association between year of study and treatment quality score, design quality score, and total quality score (sum of treatment quality and design quality). The total quality score was associated with the year of study $($ rho $=0.598, \mathrm{P}<0.001)$. Treatment quality and design quality were also associated with the year of study (rho $=0.596, \mathrm{P}<0.001 ;$ rho $=0.556, \mathrm{P}<0.001)$ respectively. Similarily, design quality was associated with treatment quality ( $r h o=0.662, \mathrm{P}<0.001)$. There were no differences in overall quality, treatment or design quality between headache and nonheadache studies. The $\mathrm{N}$ at the end of treatment was not associated with total quality score, or design and treatment quality scores when considered independently. This finding remains after accounting for trial complexity (i.e., the number of arms of a trial). Comparing the results of the quality of the studies reported in the previous published review $(n=29)$ and for this update $(\mathrm{n}=8)$, those published since Eccleston 2009 are of better overall quality (Mann Whitney $\mathrm{U}=18.5, \mathrm{P}<0.001$ ), treatment quality (Mann Whitney $\mathrm{U}=21.0, \mathrm{P}<$ 0.001 ) and design quality (Mann Whitney $\mathrm{U}=28.5, \mathrm{P}<0.001$ ). Finally, comparing those published before and since the previous version of this review (Eccleston 2009) there was no significant change in the size of the trial, that is, there was not an increase in the end of treatment $\mathrm{N}$.

Twelve analyses were attempted (pain, disability, and mood outcomes were analysed for headache and non-headache conditions at post-treatment and follow-up). One comparison had only one study contributing and so was excluded. Of the remaining 11 comparisons, five showed low heterogeneity $\left(\mathrm{I}^{2}<25 \%\right)$, four showed modest heterogeneity $\left(\mathrm{I}^{2}>=25 \%-<\right.$ $50 \%)$ and two showed large heterogeneity $\left(\mathrm{I}^{2}>=50 \%\right)$.

\section{Effects of interventions}

See: Summary of findings for the main comparison Psychological therapies for the management of chronic pain (headache) in children and adolescents; Summary of findings 2 Psychological therapies for the management of chronic (non-headache) in children and adolescents

\section{Treatment versus control (headache) post-treatment}

Eighteen studies of 748 participants were entered into an analysis of the effects of psychological treatment on pain immediately post-treatment (Barry 1997; Connelly 2006; Fichtel 2001; Griffiths 1996; Hicks 2006; Kroener-Herwig 2002; Labbe 1984; Labbe 1995; Larsson 1987a; Larsson 1987b; Larsson 1990; Larsson 1996; McGrath 1992; Osterhaus 1997; Palermo 2009; Sartory 1998; Scharff 2002; Trautmann 2010). This analysis gave an risk ratio (RR) of 2.90 (95\% confidence interval $(\mathrm{CI}) 2.25$ to $3.73 ; \mathrm{z}=8.25, \mathrm{P}<0.05$ ) for a 
clinically significant change in pain (NNTB $=2.72$; CI 2.32 to 3.29) (Figure 3; Figure 4). Three studies of 108 participants were entered into analysis of the effects of treatment on disability (Connelly 2006; Palermo 2009; Wicksell 2009). A small effect was found standardised mean difference (SMD) -0.30 ( $95 \%$ CI -0.85 to 0.24 ); and this was not significant $(\mathrm{z}=1.09, \mathrm{P}>0.05)$. Five studies of 204 participants were entered into an analysis of the effects of treatment on mood (Bussone 1998; Griffiths 1996; Palermo 2009;

Trautmann 2010; Wicksell 2009). A small effect was found SMD -0.16 (95\% CI -0.45 to $0.13)$; and this was not significant $(\mathrm{z}=1.07, \mathrm{P}>0.05)$.

\section{Treatment versus control (headache) follow-up}

Six studies of 196 participants, were entered into analysis of the effects of treatment on pain at follow-up (Connelly 2006; Hicks 2006; Labbe 1984; Larsson 1987a; Larsson 1987b; Larsson 1996). This analysis gave an RR of 3.34, (95\% CI 2.01 to 5.53; $\mathrm{z}=4.68, \mathrm{P}<$ 0.05 ), for a clinically significant change in pain (NNTB $=2.01$; CI 1.62 to 2.64). There was only one study that could be analysed for disability at follow-up (Wicksell 2009), therefore no conclusion could be drawn. Two studies with 59 participants was entered into an analysis of the effects of treatment on mood at follow-up (Bussone 1998; Wicksell 2009) finding a large effect of SMD -0.60 (95\% CI -1.13 to $-0.07 ; \mathrm{z}=2.24, \mathrm{P}<0.05)$.

\section{Treatment versus control (non-headache) post-treatment}

Twelve studies of 709 participants were entered into an analysis of the effects of psychological treatment on continuous pain outcomes immediately post-treatment (Barakat 2010; Hicks 2006; Humphreys 2000; Kashikar-Zuck 2005; Kashikar-Zuck 2012; Levy 2010; Palermo 2009; Robins 2005; Stinson 2010; van Tilburg 2009; Vlieger 2007; Wicksell 2009). A large effect size SMD -0.55 (95\% CI -0.84 to $-0.26 ; \mathrm{z}=3.70, \mathrm{P}<0.05)$ was found (Figure 5). Nine studies involving 588 participants were entered into analysis of the effects of treatment on disability (Humphreys 2000; Kashikar-Zuck 2005; Kashikar-Zuck 2012; Levy 2010; Palermo 2009; Robins 2005; Stinson 2010; van Tilburg 2009; Wicksell 2009). A small but significant effect was found SMD $-0.29(95 \% \mathrm{CI}-0.49$ to $-0.10 ; \mathrm{z}=2.99, \mathrm{P}<$ 0.05 ). Six studies of 435 participants were entered into analysis of the effects of treatment on mood (Kashikar-Zuck 2005; Kashikar-Zuck 2012; Levy 2010; Palermo 2009; Stinson 2010; Wicksell 2009). A small effect size was found SMD -0.14 (95\% CI -0.42 to 0.15 ); and this was not significant $(\mathrm{z}=0.92, \mathrm{P}>0.05)$.

\section{Treatment versus control (non-headache) follow-up}

Five studies of 357 participants, had data available for analysis of the effects of treatment on pain at follow-up (Barakat 2010; Hicks 2006; Kashikar-Zuck 2012; Levy 2010; Wicksell 2009). A small effect size was found SMD -0.17 (95\% CI -0.60 to 0.26 ) and this was not significant $(\mathrm{z}=0.77, \mathrm{P}>0.05)$. Three studies of 292 participants were entered into an analysis of the effects of treatment on disability (Kashikar-Zuck 2012; Levy 2010; Wicksell 2009). A small effect size was found SMD -0.19 (95\% CI -0.51 to 0.13 ) and this was not significant $(\mathrm{z}=1.14 ; \mathrm{P}>0.05)$. Three studies of 292 participants were entered into an analysis of the effects of treatment on mood (Kashikar-Zuck 2012; Levy 2010; Wicksell 2009). A small effect size was found SMD -0.09 (95\% CI -0.32 to 0.14 ) and this was not significant $(\mathrm{z}=0.74, \mathrm{P}>0.05)$.

\section{DISCUSSION}

\section{Evidence base}

Eight additional studies (end of treatment $\mathrm{n}=506$ ) were added in this update providing a total of 37 studies and an overall sample of 1938 participants. The outcomes measured and 
the categories of measurement remain the same. In multi-arm trials involving more than one treatment or control group, similar treatments or control groups were combined for the purposes of the analyses. The majority of studies used one or two treatment conditions in comparison to a waiting list or standard care control group. Similar to the previous review, the treatments could still be categorised as behavioural or cognitive behavioural although the data were not analysed in this way. The average length of treatment for headache studies was 5.3 hours, and for non-headache studies it was considerably shorter ( $\mathrm{M}=3.5$ hours). Follow-up data are increasingly being reported in more recent studies and were included when relevant. The overall quality of the studies has improved since the previous review (Eccleston 2009), although the size of the samples did not increase over time.

The inclusion of further studies has extended the evidence base. Of the 12 possible analyses, five were significant, and three were different from the previous review. Pain intensity was found to improve for headache and non-headache groups at post-treatment, and for the headache group at follow-up. Forty-nine per cent of children with headaches significantly improved their pain scores at post-treatment after receiving psychological therapy compared with only $17 \%$ in the control group. However, the addition of more studies to the nonheadache pain intensity analysis at follow-up meant this was no longer significant. Disability was significantly improved in non-headache analyses at post-treatment, although the effect size was small. This was also true for mood in the headache group at follow-up. However, this should be interpreted with caution as there were only two studies available for analysis.

Pain intensity was the most common treatment outcome assessed, with 18 studies of children with headache and 12 of children with non-headache pain providing data on pain intensity that could be analysed. An NNTB of 2.72 for psychological therapies to produce more than 50\% relief in pain in children with headaches was found. An NNTB of 2.01 was found for the smaller number of trials reporting follow-up. Large effect sizes were also found for reduction in pain intensity in non-headache chronic and recurrent pain at posttreatment. However, the confidence intervals around the effects are large.

\section{Issues for consideration}

Further to the previous update, there have been developments in the field which are reflected in the updated trials. All of the new trials used cognitive behavioural therapy compared to purely behavioural therapy. Five of the eight updated studies were non-headache trials, and a further two included mixed samples and so were included in both headache and nonheadache analyses. All the updated studies provide data on mood and disability, and four studies provided data that could be entered into the follow-up analyses thereby allowing a better estimate of the maintenance of interventions. Reflecting advances in treatment delivery, four updated studies (six in total) used computer applications (internet and/or CDROM) to provide treatment to the children.

In regard to condition, this review included 21 headache studies, seven abdominal pain studies, two sickle cell disease studies, two fibromyalgia studies, four mixed pain studies and one juvenile idiopathic arthritis study. Psychological treatment still appears to have a minimal impact on disability and mood despite reporting two significant effects from this update. Previously, we reported that mood and disability outcomes in trials with children with chronic pain were a focus for trials (McGrath 2008) and this seems to be the case as seven of the eight updated studies had extractable data for disability analyses and five out of eight studies provided extractable data for mood analyses. As these outcomes are being measured and reported more frequently, standardised measurements should be used consistently across the field of paediatric chronic pain and treatments should specifically target changes in these areas. 
One limitation of this review is that we are unable to fully discuss the effectiveness of psychological interventions as they were compared with a control group that combined active (e.g. education) and wait-list controls. Just over half the studies used active controls, yet we did not feel that it was an appropriate sample to separate for analysis as has been done in a companion review of treatments for adults with pain (Eccleston 2009a). This limitation may contribute to an overestimation of the treatment effects since it is not possible to separate differences specific to treatment versus active treatment or waiting list control.

\section{AUTHORS' CONCLUSIONS}

\section{Implications for practice}

Psychological treatments, principally relaxation and cognitive behavioural therapies, are effective treatments of childhood headache pain at post-treatment and follow-up, and mood at follow-up. Behavioural and cognitive behavioural treatments are also effective in reducing non-headache pain, and disability at post-treatment. There is insufficient evidence to explain the effectiveness of psychological interventions for individual non-headache pain conditions due to the limited number of studies for each condition.

\section{Implications for research}

Since the original version of this review there has been an improvement in the evidence base by the addition of new studies, and the extension into non-headache pain conditions, and treatments that rely on more complex methods. This update adds studies to the previous review so readers are able to understand the effects that psychological interventions have for headache and non-headache pain. However, this structure limits our understanding of whether psychological therapies are unique in their improvement of symptoms in comparison to active or wait-list control groups, yet we felt this was important to present before introducing further analyses. The author team are considering the following possible changes for the next version of the review.

1. Increasing the current criterion of 10 participants in both the treatment and control groups at the point of analysis, to 20 .

2. Splitting the title into two titles: one based on headache only and one based on treatment for non-headache disorders.

3. Introducing sub-group analysis to focus on critical issues in therapy such as type of therapy, dose of therapy, location of therapy, and involvement of other quasi therapeutic agents (e.g., parents).

\section{Measurement}

Measurement of non-pain outcomes is increasing and should continue to be included and reported in trials with children and adolescents. Recommendations are now available with regards to evidence based assessment of relevant domains for trials of chronic and recurrent pain in children (McGrath 2008). Measures have been developed to assess the majority of these domains. However, additional validation work is needed particularly on child disability outcome measures. Currently available measures have several limitations including a lack of data on sensitivity to change and factor structure, and do not have established cut-off scores to aid in interpretation of scores as situated in the clinical versus normative range (Palermo 2008). It is currently unclear whether treatments might be effective at changing particular aspects of disability because the measures lump together various concepts such as vigorous physical activity, role functioning (e.g., school attendance), and regular activity participation. Future validation work may help disentangle this complex and multidimensional domain. 


\section{Treatment}

Studies in this review are dominated by behavioural or cognitive behavioural treatments. However, more recent studies show a shift towards cognitive behavioural therapy. There is now a call for more varied psychological therapies that have been used in other pae-diatric chronic illnesses such as diabetes (multisystemic therapy), cancer (problem-solving therapy) and asthma (family therapy). Such therapies in painful conditions would give a broader understanding of which therapies can work for a particular population. There is also a need for more trials in non-headache conditions as we are as yet unable to understand the effectiveness of psychological interventions in specific conditions such as sickle cell disease. There have been developments in the delivery of treatments with technology advances. Five trials delivered their therapy using a computer- or internet-based programme (Connelly 2006; Hicks 2006; Palermo 2009; Trautmann 2010; Wicksell 2009). This delivery mode has the ability to reach more patients quicker, and in this digital age, these treatments are fast becoming the most accessible. As reported in the previous review, important information is still lacking in trials such as treatment expectations, treatment history, baseline pain and disability which is important to understand how and why some treatments are more effective than others. Similarly, treatment response is precluded by individual differences of the trials and samples, such as small sample sizes, mixed illness groups and wide age ranges included in the current trials.

\section{Trial design}

Trials have improved in quality and updated trials include follow-up periods so we are better able to understand the maintenance of treatment effects. However, the number of participants entering treatments is still small and should be increased in future trials, and multi-site collaboration is needed to achieve this. More trials are needed in non-headache pain conditions so as to determine the effectiveness of psychological therapies for individual conditions. Therapies should also be tailored to the child and families' needs, and sociodemographic differences should be explored and reported. Treatments delivered are to date dominated by behavioural or cognitive behavioural therapy. Future trials should expand beyond these therapy groups to identify if other therapies are effective for chronic pain conditions and all treatments should include specific content to improve disability and mood. Finally, new trials should use active comparators over wait-list control groups.

\section{Supplementary Material}

Refer to Web version on PubMed Central for supplementary material.

\section{Acknowledgments}

We would like to thank Kiki Mastroyannopoulou and Louise Yorke for their contributions to the original version of this review. Thank you also to Hannah Somhegyi for help with coding and data management and to Jane Hayes for running the updated search. Finally, thanks also go to the PaPaS review group team and to the peer referees for their helpful comments.

\section{SOURCES OF SUPPORT}

Internal sources

- $\quad$ No sources of support supplied

External sources

- New Source of support, Not specified. 


\section{REFERENCES}

* Indicates the major publication for the study

\section{References to studies included in this review}

Abram HS, Buckloh LM, Schilling LS, Armatti Wiltrout S, Ramirez-Garnica G, Turk WR. A randomized, controlled trail of a neurological and psychoeducational group appointment model for pediatric headaches. Children's Healthcare. 2007; 36:249-265.

Alfven G, Lindstrom A. A new method for the treatment of recurrent abdominal pain of prolonged negative stress origin. Acta Pediatrica. 2007; 96:76-81.

Barakat LP, Schwartz LA, Salamon KS, Radcliffe J. A family-based randomized controlled trial of pain intervention for adolescents with sickle cell disease. Journal of Pediatric Hematology/ Oncology. 2010; 32(7):540-547. [PubMed: 20686425]

Barry J, von Baeyer CL. Brief cognitive-behavioral group treatment for children's headache. Clinical Journal of Pain. 1997; 13:215-220. [PubMed: 9303253]

Bussone G, Grazzi L, D’Amico D, Leone M, Andrasik F. Biofeedback-assisted relaxation training for young adolescents with tension-type headache: A controlled study. Cephalalgia. 1988; 18:463-467. [PubMed: 9793698]

Connelly M, Rapoff MA, Thompson N, Connelly W. Headstrong: A pilot study of a cd-rom intervention for recurrent pediatric headache. Journal of Pediatric Psychology. 2006; 31:737-747. [PubMed: 16861397]

Duarte MA, Penna FJ, Andrade EM, Cancela CSP, Neto JCA, Barbosa TF. Treatment of nonorganic recurrent abdominal pain: Cognitive-behavioral family intervention. Journal of Pediatric Gastroenterology and Nutrition. 2006; 43:59-64. [PubMed: 16819378]

Fitchel A, Larsson B. Does relaxation treatment have differential effects on migraine and tension-type headache in adolescents. Headache. 2001; 41:290-296. [PubMed: 11264690]

Gil KM, Wilson JJ, Edens JL, Workman E, Ready J, Sedway J, et al. Cognitive coping skills training in children with sickle cell disease pain. International Journal of Behavioural Medicine. 1997; 4:364-377.

Griffiths JD, Martin PR. Clinical versus home-based treatment formats for children with chronic headache. The British Journal of Health Psychology. 1996; 1:151-166.

Hicks CL, von Baeyer CL, McGrath PJ. Online psychological treatment for pediatric recurrent pain: A randomized evaluation. Journal of Pediatric Psychology. 2006; 31:724-736. [PubMed: 16093516]

Humphreys PA, Gevirtz RN. Treatment of recurrent abdominal pain: Components analysis of four treatment protocols. Journal of Pediatric Gastroenterology and Nutrition. 2000; 31:47-51. [PubMed: 10896070]

Kashikar-Zuck S, Swain NF, Jones BA, Graham TB. Efficacy of cognitive-behavioral intervention for juvenile primary fibromyalgia syndrome. The Journal of Rheumatology. 2005; 32:1594-1602. [PubMed: 16078340]

Kashikar-Zuck S, Ting TV, Arnold LM, Bean J, Powers SW, Graham B, et al. Cognitive behavioral therapy for the treatment of juvenile fibromyalgia. Arthritis \& Rheumatism. 2012; 64(1):297-305. [PubMed: 22108765]

Kroener-Herwig B, Denecke H. Cognitive-behavioral therapy of pediatric headache: Are there differences in efficacy between a therapist-administered group training and a self-help format? Journal of Psychosomatic Research. 2002; 53:1107-1114. [PubMed: 12479993]

Labbe EE, Williamson DA. Treatment of childhood migraine using autogenic feedback training. Journal of Consulting and Clinical Psychology. 1984; 52(6):968-976. [PubMed: 6520289]

Labbe EE. Treatment of childhood migraine with autogenic training and skin temperature biofeedback: a component analysis. Headache. 1995; 35:10-13. [PubMed: 7868327]

Larsson B, Daleflod B, Hakansson L, Melin L. Therapist-assisted versus self-help relaxation treatment of chronic headaches in adolescents: a school-based intervention. Journal of Child Psychology. 1987; 28(1):127-136. 
Larsson B, Melin L, Lamminen M, Ullstedt F. A school-based treatment of chronic headaches in adolescents. Journal of Pediatric Psychology. 1987; 12(4):553-566. [PubMed: 3323446]

Larsson B, Melin L, Doberl A. Recurrent tension headache in adolescents treated with self-help relaxation training and a muscle relaxant drug. Headache. 1990; 30:665-671. [PubMed: 2272819]

Larsson B, Carlsson J. A school-based, nurse-administered relaxation training for children with chronic tension-type headache. Journal of Pediatric Psychology. 1996; 21(5):603-614. [PubMed: 8936891]

Levy RL, Langer SL, Walker LS, Romano JM, Christie DL, Youssef N, et al. Cognitive-behavioral therapy for children with functional abdominal pain and their parents decreases pain and other symptoms. American Journal of Gastroenterology. 2010; 105(4):946-956. [PubMed: 20216531]

McGrath PJ, Humphreys P, Goodman JT, Keene D, Firestone P, et al. Relaxation prophylaxis for childhood migraine: a randomized placebo-controlled trial. Developmental Medicine and Child Neurology. 1988; 30:626-631. [PubMed: 3229560]

McGrath PJ, Humphreys P, Keene D, Goodman JT, Lascelles MA, Cunningham SJ, et al. The efficacy and efficiency of a self-administered treatment for adolescent migraine. Pain. 1992; 49:321-324. [PubMed: 1408297]

Osterhaus SOL, Lange A, Linssen WHJP, Passchier J. A behavioral treatment of young migrainous and nonmigrainous headache patients: prediction of treatment success. International Journal of Behavioral Medicine. 1997; 4(4):378-396. [PubMed: 16250725]

Palermo TM, Wilson AC, Peters M, Lewandowski A, Somhegyi H. Randomized controlled trial of an internet delivered family cognitive behavioral therapy intervention for children and adolescents with chronic pain. Pain. 2009; 146(1-2):205-13. [PubMed: 19695776]

Passchier J, van den Bree MBM, Emmen HH, Osterhaus SOL, Orlebeke JF, Verhage F. Relaxation training in school classes does not reduce headache complaints. Headache. 1990; 30:660-664. [PubMed: 2272818]

Richter IL, McGrath PJ, Humphreys PJ, Goodman JT, Firestone P, Keene D. Cognitive and relaxation treatment of paediatric migraine. Pain. 1986; 25:195-203. [PubMed: 3523394]

Robins PM, Smith SM, Glutting JJ, Bishop CT. A randomized controlled trial of a cognitivebehavioral family intervention for pediatric recurrent abdominal pain. Journal of Pediatric Psychology. 2005; 30:397-408. [PubMed: 15944167]

Sanders MR, Shepherd RW, Cleghorn G, Woolford H. The treatment of recurrent abdominal pain in children: a controlled comparison of cognitive-behavioral family intervention and standard pediatric care. Journal of Consulting and Clinical Psychology. 1994; 62(2):306-314. [PubMed: 8201068]

Sartory G, Muller B, Metsch J, Pothmann R. A comparison of psychological and pharmacological treatment of pediatric migraine. Behaviour Research and Therapy. 1998; 36:1155-1170. [PubMed: 9745800]

Scharff L, Marcus DA, Masek BJ. A controlled study of minimal-contact thermal biofeedback treatment in children with migraine. Journal of Pediatric Psychology. 2002; 27:109-119. [PubMed: 11821495]

Stinson JN, McGrath PJ, Hodnett ED, Feldman BM, Duffy CM, Huber AM, et al. An internet-based self-management program with telephone support for adolescents with arthritis: a pilot randomized controlled trial. Journal of Rheumatology. 2010; 37(9):1944-1952. [PubMed: 20595280]

Trautmann E, Kroner-Herwig B. A randomized controlled trial of internet-based self-help training for recurrent headache in childhood and adolescence. Behaviour Research and Therapy. 2010; 48:2837. [PubMed: 19782343]

van Tilburg MAL, Chitkara DK, Palsson OS, Turner M, Blois-Martin N. Audio-recorded guided imagery treatment reduces functional abdominal pain in children: a pilot study. Pediatrics. 2009; 124(5):e890-e897. [PubMed: 19822590]

Vlieger AM, Menko-Frankenhuis C, Wolfkamp SC, Tromp E, Benninga MA. Hypnotherapy for children with functional abdominal pain or irritable bowel syndrome: A randomized controlled trial. Gastroenterology. 2007; 133:1430-1436. [PubMed: 17919634] 
Wicksell RK, Melin L, Lekander M, Olsson GL. Evaluating the effectiveness of exposure and acceptance strategies to improve functioning and quality of life in longstanding pediatric pain - A randomized controlled trial. Pain. 2009; 141:248-257. [PubMed: 19108951]

\section{References to studies excluded from this review}

Fentress DW, Masek BJ, Mehegan JE, Benson H. Biofeedback and relaxation-response training in the treatment of pediatric migraine. Developmental Medicine and Child Neurology. 1986; 28:139146. [PubMed: 3519327]

Kroner-Herwig B, Mohn U, Pothmann R. Comparison of biofeedback and relaxation in the treatment of pediatric headache and the influence of parent involvement on outcome. Applied Psychophysiology and Biofeedback. 1998; 23:143-157. [PubMed: 10384247]

Larsson B, Melin L. Chronic headaches in adolescents: treatment in a school setting with relaxation training as compared with information-contact and self-registration. Pain. 1986; 25:325-336. [PubMed: 3528989]

Olness K, MacDonald JT, Uden DL. Comparison of self-hypnosis and propranolol in the treatment of juvenile classic migraine. Pediatrics. 1987; 79(4):593-597. [PubMed: 3822681]

Sanders MR, Rebgetz M, Morrison M, Bor W, Gordon A, Dadds M, et al. Cognitive-behavioral treatment of recurrent nonspecific abdominal pain in children: an analysis of generalization, maintenance, and side effects. Journal of Consulting and Clinical Psychology. 1989; 57(2):294300. [PubMed: 2708618]

Trautmann E, Kroner-Herwig B. Internet-based self-help training for children and adolescents with recurrent headache: a pilot study. Bheavioural and Cognitive Psychotherapy. 2008; 36:241-245.

Vlieger AM, Rutten JMTM, Govers AMAO, Frankenhuis C, Benninga MA. Long-term follow-up of gut-directed hypnotherapy vs. standard care in children with functional abdominal pain or irritable bowel syndrome. American Journal of Gastroenterology. 2012; 107:627-631. [PubMed: 22310221]

Weydert JA, Shapiro DE, Acra SA, Monheim CJ, Chambers AS, Ball TM. Evaluation of guided imagery as treatment for recurrent abdominal pain in children: a randomized controlled trial. BMC Pediatrics. 2006; 6(29):1-10. [PubMed: 16457711]

Youssef NN, Van Tilburg MA, Matta EN, Langseder A, Whitehead WE. Feasibility and efficacy of pilot study investigating a school nurse administered guided imagery program for childhood functional abdominal pain. Gastroenterology. 2009; 136(5):156-157.

\section{Additional references}

Bursch B, Walco GA, Zeltzer L. Clinical assessment and management of chronic pain and painassociated disability syndrome. Developmental and Behavioral Pediatrics. 1998; 19:45-53.

Cohen J. A power primer. Psychological Bulletin. 1992; 112(1):155-159. [PubMed: 19565683]

Eccleston C, Malleson PN, Clinch J, Connell H, Sourbut C. Chronic pain in adolescents: evaluation of a programme of interdisciplinary cognitive behaviour therapy. Archives of Diseases in Childhood. 2003; 88:881-885. [PubMed: 14500306]

Eccleston C, Williams ACdeC, Morley S. Psychological therapies for the management of chronic pain (excluding headache) in adults. Cochrane Database of Systematic Reviews. 2009; (Issue 2)

Fearon P, Hotopf M. Relation between headache in childhood and physical and psychiatric symptoms in adulthood: National birth cohort study. BMJ. 2001; 322:1145. [PubMed: 11348907]

Fordyce WE, Fowler RS Jr, Lehmann JF, DeLateur BJ. Some implications of learning on problems of chronic pain. Journal of Chronic Disease. 1968; 21:179-190.

Hermann C, Kim M, Blanchard EB. Behavioral and prophylactic pharmacological intervention studies of pediatric migraine: an exploratory meta-analysis. Pain. 1995; 60:239-256. [PubMed: 7596620]

Higgins, JPT.; Green, S. Cochrane Handbook for Systematic Reviews of Interventions Version 5.1.0 [updated March 2011]. The Cochrane Collaboration; 2011. 2012

Holden EW, Deichmann MM, Levy J. Empirically supported treatments in pediatric psychology: recurrent pediatric headache. Journal of Pediatric Psychology. 1999; 24:91-109. [PubMed: 10361386] 
Huertas-Ceballos A, Logan S, Bennett C, Macarthur C. Psychosocial interventions for recurrent abdominal pain (RAP) and irritable bowel syndrome (IBS) in childhood. Cochrane Database of Systematic Reviews. 2008; (Issue 1)

Janicke DM, Finney JQ. Empirically supported treatments in pediatric psychology: recurrent abdominal pain. Journal of Pediatric Psychology. 1999; 24:115-127. [PubMed: 10361390]

Keefe FJ, Rumble ME, Scipio CD, Giordano LA, Perri LM. Psychological aspects of persistent pain: current state of the science. Journal of Pain. 2004; 5:195-211. [PubMed: 15162342]

Kibby MY, Tyc VL, Mulhern RK. Effectiveness of psychological intervention for children and adolescents with chronic medical illness: a meta-analysis. Clinical Psychology Reviews. 1998; 18:103-117.

Masek BJ. Commentary: The pediatric migraine connection. Journal of Pediatric Psychology. 1999; 24:110. [PubMed: 10361387]

McGrath, PA. Pain in Children: Nature, Assessment \& Treatment. The Guilford Press; 1990.

McGrath, PJ.; Finley, GA. Chronic and Recurrent Pain in Children and Adolescents. Seattle: IASP Press; 1999.

McGrath PJ, Walco G, Turk DC, Dworkin RH, Brown MT, Davidson K, et al. Core outcome domains and measures for pediatric acute and chronic/recurrent pain clinical trials: PedIMMPACT recommendations. Journal of Pain. 2008; 9:771-783. [PubMed: 18562251]

Palermo TM. Impact of recurrent and chronic pain on child and family daily functioning: A critical review of the literature. Journal of Developmental and Behavioral Pediatrics. 2000; 21:58-69. [PubMed: 10706352]

Palermo TM, Chambers CT. Parent and family factors in pediatric chronic pain and disability: An integrative approach. Pain. 2005; 119:1-4. [PubMed: 16298492]

Palermo TM, Long A, Lewandowski A, Drotar D, Quittner A, Walker L. Evidence based assessment of health related quality of life and functional impairment. Journal of Pediatric Psychology. 2008; 33:983-996. [PubMed: 18430762]

Palermo, TP. Cognitive-Behavioral Therapy for Chronic Pain in Children and Adolescents. New York: Oxford University Press; 2012.

Perquin CW, Hazebroek-Kampscheur AAJM, Hunfeld JAM, Bohnene AM, van Suijlekom-Smit LWA, Passchier J, et al. Pain in children and adolescents: a common experience. Pain. 2000; 87:51-58. [PubMed: 10863045]

Perquin CW, Hazebroek-Kampscheur AAJM, Hunfeld JAM, van Suijlekom-Smit LWA, Passchier J, van der Wouden JC. Chronic pain among children and adolescents: physician consultation and medication use. Clinical Journal of Pain. 2001; 16:229-235. [PubMed: 11014396]

Shojania KG, Sampson M, Ansari MT, Jun J, Doucette S, Moher D. How quickly do systematic reviews go out of date? A survival analysis. Annals of Internal Medicine. 2007; 147:224-233. [PubMed: 17638714]

Stanford EA, Chambers CT, Biesanz JC, Chen E. The frequency, trajectories and predictors of adolescent recurrent pain: A population-based approach. Pain. 2008; 138:11-21. [PubMed: 18093737]

Trautmann E, Lackschewitz H, Kroner-Herwig B. Psychological treatment of recurrent headache in children and adolescents--a meta-analysis. Cephalalgia. 2006; 26(12):1411-1426. [PubMed: 17116091]

Walco GA, Sterling CM, Conte PM, Engel RG. Empirically supported treatments in pediatric psychology: disease related pain. Journal of Pediatric Psychology. 1999; 24:155-167. [PubMed: 10361396]

Walker L, Greene J. Children with recurrent abdominal pain and their parents: more somatic complaints, anxiety, and depression than other patient families? Journal of Pediatric Psychology. 1989; 14:231-293. [PubMed: 2754574]

Weydert JA, Ball TM, Davis MF. Systematic review of treatments for recurrent abdominal pain. Pediatrics. 2003; 111:e1-e11. [PubMed: 12509588]

Yates SL, Morley S, Eccleston E, Williams ACdeC. A scale for rating the quality of psychological trials for pain. Pain. 2005; 117:314-325. [PubMed: 16154704] 


\section{References to other published versions of this review}

Eccleston C, Yorke L, Morley S, Williams ACdeC, Mastroyannopoulou A. Psychological therapies for the management of chronic and recurrent pain in children and adolescents. Cochrane Database of Systematic Reviews. 2003; (Issue 1)

Eccleston C, Palermo TM, Williams ACDC, Lewandowski A, Morley S. Psychological therapies for the management of chronic and recurrent pain in children and adolescents. Cochrane Database of Systematic Reviews. 2009; (Issue 2)

\section{APPENDICES}

\section{Appendix 1. Search Strategies}

\section{Medline via Ovid search strategy}

1. exp child/

2. Infant/

3. Adolescent/

4. (child $\$$ or adolescent $\$$ or infant $\$$ or juvenil $\$$ or pediatric $\$$ or paediatric $\$$ or "young person\$" or "young people" or youth\$ or "young adult\$").ab,ti,kf.

5. 1 or 2 or 3 or 4

6. exp Psychology/

7. $\exp$ Psychotherapy/

8. $\exp$ Behavior Therapy/

9. (psycholog $\$$ or (behavio?r and therapy) or hypnos $\$$ or relaxation $\$$ or ((family or color or colour or music or play) adj therap\$) or imagery or cogniti $\$$ or psychotherap\$).ab,ti,kf.

10. 6 or 7 or 8 or 9

11. (pain\$ or headache $\$$ or "headache\$" or head-ache\$ or migraine\$ or cephalalgi\$ or "stomachache\$" or "tummy ache\$" or "abdominal ache\$" or "belly ache\$" or earache\$ or ear-ache\$ or toothache\$ or tooth-ache\$ or odontalgi\$ or dysmenorrh\$ or neuralgi\$).ab,ti,kf.

12. exp Pain/

13. exp Headache Disorders/

14. 11 or 12 or 13

15. 5 and 10 and 14

\section{Cochrane sensitive search strategy filter for RCTs (OVID version for MEDLINE searches)}

Cochrane Highly Sensitive Search Strategy for identifying randomized trials in MEDLINE: sensitivity maximising version (2008 revision) as referenced in Chapter 6.4.11 and detailed in boxes 6.4.c of The Cochrane Handbook for Systematic Reviews of Interventions Version 5.0.0 [updated February 2008].

1. randomized controlled trial.pt.

2. controlled clinical trial.pt.

3. randomized.ab. 
4. placebo.ab.

5. drug therapy.fs.

6. randomly.ab.

7. trial.ab.

8. groups.ab.

9. or $/ 1-8$

10. humans.sh.

11. 9 and 10

\section{EMBASE via Ovid search strategy}

1. Child/

2. Infant/

3. Adolescent/

4. (child $\$$ or adolescent $\$$ or infant $\$$ or juvenil $\$$ or pediatric $\$$ or paediatric $\$$ or "young person\$" or "young people" or youth\$ or “young adult\$”).ab,ti.

5. 1 or 2 or 3 or 4

6. $\exp$ PSYCHOLOGY/

7. exp PSYCHOTHERAPY/

8. behavior therapy/

9. (psycholog $\$$ or (behavio?r and therapy) or hypnos $\$$ or relaxation $\$$ or ((family or color or colour or music or play) adj therap\$) or imagery or cogniti $\$$ or psychotherap\$).ab,ti.

10. 6 or 7 or 8 or 9

11. (pain\$ or headache\$ or "headache\$" or head-ache\$ or migraine\$ or cephalalgi\$ or "stomachache\$" or "tummy ache\$" or "abdominal ache\$" or "belly ache\$" or earache $\$$ or ear-ache\$ or toothache\$ or tooth-ache\$ or odontalgi $\$$ or dysmenorrh\$ or neuralgi\$).ab,ti.

12. exp Pain/

13. exp "Headache and Facial Pain"/

14. 11 or 12 or 13

15. 5 and 10 and 14

The above subject search was linked to the following filter for EMBASE via OVID

1. random $\$ . t i, a b$.

2. factorial\$.ti,ab.

3. (crossover\$ or cross over $\$$ or cross-over $\$$ ).ti,ab.

4. placebo\$.ti,ab.

5. (doubl\$ adj blind $\$$ ).ti,ab.

6. (singl\$ adj blind\$).ti,ab. 
7. assign\$.ti,ab.

8. allocat $\$ . t i, a b$.

9. volunteer\$.ti,ab.

10. CROSSOVER PROCEDURE.sh.

11. DOUBLE-BLIND PROCEDURE.sh.

12. RANDOMIZED CONTROLLED TRIAL.sh.

13. SINGLE BLIND PROCEDURE.sh.

14. or/1-13

15. ANIMAL/ or NONHUMAN/ or ANIMAL EXPERIMENT/

16. HUMAN/

17. 16 and 15

18. 15 not 17

19. 14 not 18

\section{PsychInfo via OVID}

1. (child $\$$ or adolescent $\$$ or infant $\$$ or juvenil $\$$ or pediatric $\$$ or paediatric $\$$ or "young person\$" or "young people" or youth\$ or “young adult\$”).ab,ti.

2. exp PSYCHOLOGY/

3. exp PSYCHOTHERAPY/

4. behavior therapy/

5. (psycholog $\$$ or (behavio?r and therapy) or hypnos $\$$ or relaxation $\$$ or ((family or color or colour or music or play) adj therap\$) or imagery or cogniti\$ or psychotherap\$).ab,ti.

6. 2 or 3 or 4 or 5

7. (pain $\$$ or headache $\$$ or "head ache\$" or head-ache $\$$ or migraine $\$$ or cephalalgi $\$$ or "stomach ache\$" or "tummy ache\$" or "abdominal ache\$" or "belly ache\$" or earache $\$$ or ear-ache $\$$ or toothache $\$$ or tooth-ache $\$$ or odontalgi $\$$ or dysmenorrh\$ or neuralgi\$).ab,ti.

8. exp Pain/

9. Headache/

10. Migraine Headache/

11. Muscle Contraction Headache/

12. 7 or 8 or 9 or 10 or 11

13. 1 and 6 and 12 


\section{WHAT'S NEW}

Last assessed as up-to-date: 12 November 2012.

Date Event Description

24 October $2012 \quad \begin{aligned} & \text { New search has } \\ & \text { been performed }\end{aligned}$

New authors have been added to this review. A new search was run in March 2012. Eight new studies were added (Barakat 2010; Kashikar-Zuck 2012; Levy 2010; Palermo 2009; Stinson 2010; Trautmann 2010; van Tilburg 2009; Wicksell 2009), and four new studies

were excluded (Trautmann 2008; Vlieger 2012; Weydert 2006;

Youssef 2009).

24 October $2012 \quad$ New citation $\quad$ The previous review reported psychological treatments required and were effective for headache and non-headache groups at

conclusion post-treatment and effects were maintained at follow-up. Updated studies have altered previous results. The current update found pain improved at post-treatment for headache and non-headache groups, and for headache groups at follow-up. An additional significant finding for disability at post-treatment for the non-headache group was found. Conclusions have been updated accordingly 


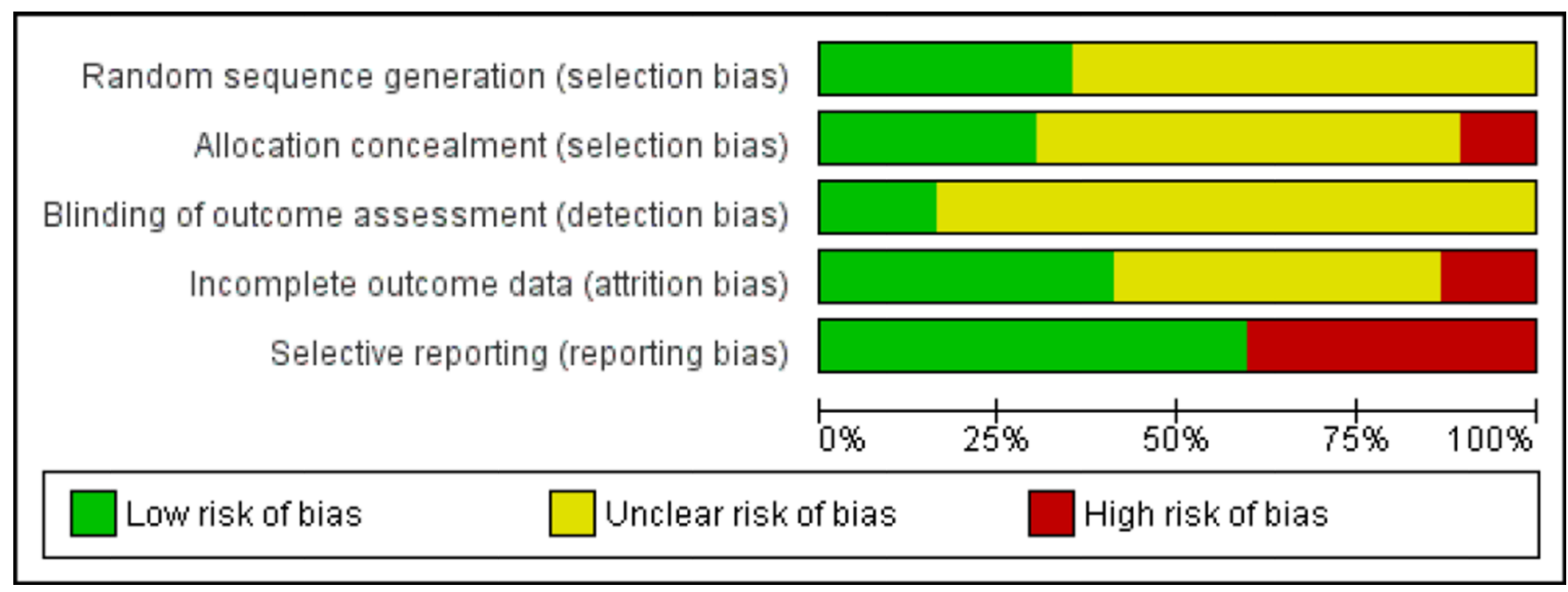

Figure 1.

Methodological quality graph: review authors' judgements about each methodological quality item presented as percentages across all included studies. 


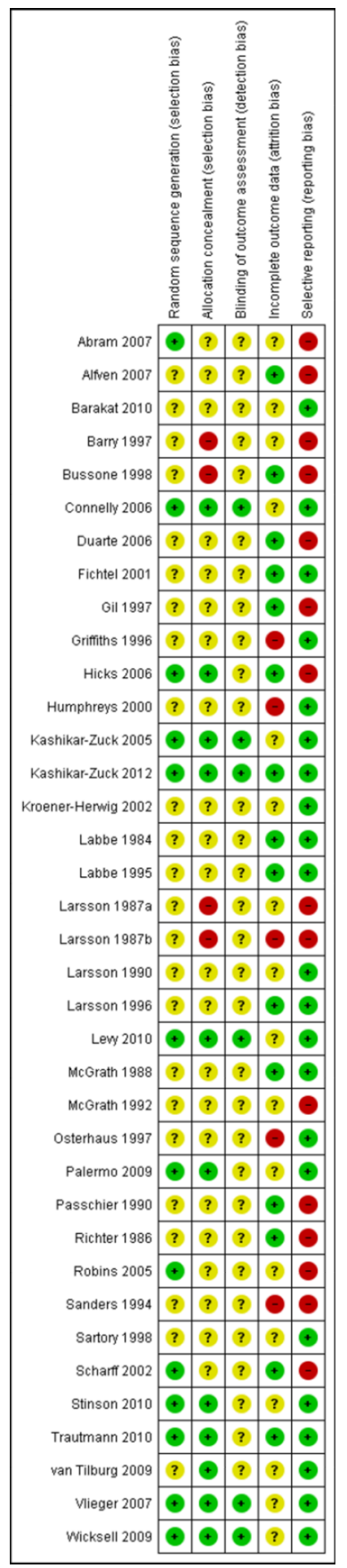

Figure 2.

Methodological quality summary: review authors' judgements about each methodological quality item for each included study. 


\begin{tabular}{|c|c|c|c|c|c|c|c|c|c|}
\hline Study or Subgroup & \multicolumn{2}{|c|}{ Experimental } & \multicolumn{2}{|c|}{ Control } & Weight & $\begin{array}{c}\text { Risk Ratio } \\
\text { M-H, Fixed, } 95 \% \text { Cl }\end{array}$ & \multicolumn{3}{|c|}{$\begin{array}{c}\text { Risk Ratio } \\
\text { M-H, Fixed, } 95 \% \mathrm{Cl}\end{array}$} \\
\hline Barry 1997 & 2 & 12 & 2 & 17 & $2.6 \%$ & $1.42[0.23,8.70]$ & & & \\
\hline Connelly 2006 & 9 & 17 & 4 & 20 & $5.9 \%$ & $2.65[0.99,7.08]$ & & & \\
\hline Fichtel 2001 & 10 & 20 & 2 & 16 & $3.5 \%$ & $4.00[1.02,15.72]$ & & & \\
\hline Griffiths 1996 & 21 & 30 & 3 & 12 & $6.8 \%$ & $2.80[1.02,7.67]$ & & & \\
\hline Hicks 2006 & 15 & 21 & 3 & 16 & $5.4 \%$ & $3.81[1.33,10.94]$ & & & \\
\hline Kroener-Hewig 2002 & 31 & 56 & 8 & 19 & $19.1 \%$ & $1.31[0.74,2.34]$ & & & - \\
\hline Labbe 1984 & 13 & 14 & 1 & 14 & $1.6 \%$ & $13.00[1.96,86.42]$ & & & \\
\hline Labbe 1995 & 19 & 20 & 6 & 10 & $12.8 \%$ & $1.58[0.95,2.65]$ & & & - \\
\hline Larsson 1987a & 13 & 30 & 1 & 11 & $2.3 \%$ & $4.77[0.70,32.29]$ & & & \\
\hline Larsson $1987 \mathrm{~b}$ & 7 & 22 & 1 & 12 & $2.1 \%$ & $3.82[0.53,27.48]$ & & & \\
\hline Larsson 1990 & 6 & 31 & 0 & 17 & $1.0 \%$ & $7.31[0.44,122.42]$ & & & \\
\hline Larsson 1996 & 9 & 13 & 1 & 13 & $1.6 \%$ & $9.00[1.32,61.24]$ & & & \\
\hline McGrath 1992 & 26 & 47 & 6 & 25 & $12.5 \%$ & $2.30[1.10,4.85]$ & & & $\rightarrow$ \\
\hline Osterhaus 1997 & 13 & 25 & 0 & 14 & $1.0 \%$ & $15.58[1.00,243.71]$ & & & \\
\hline Palermo 2009 & 10 & 23 & 3 & 21 & $5.0 \%$ & $3.04[0.97,9.58]$ & & & \\
\hline Sartory 1998 & 20 & 30 & 5 & 13 & $11.1 \%$ & $1.73[0.83,3.61]$ & & & $\rightarrow$ \\
\hline Scharff 2002 & 7 & 13 & 1 & 23 & $1.2 \%$ & $12.38[1.71,89.86]$ & & & \\
\hline Trautmann 2010 & 16 & 35 & 2 & 16 & $4.4 \%$ & $3.66[0.95,14.05]$ & & & \\
\hline Total $(95 \% \mathrm{Cl})$ & & 459 & & 289 & $100.0 \%$ & $2.90[2.25,3.73]$ & & & 슨 \\
\hline Total events & 247 & & 49 & & & & & & \\
\hline $\begin{array}{l}\text { Heterogeneity: } \mathrm{Ch}^{\mathbf{z}}=2 \\
\text { Test for overall effect: } Z\end{array}$ & $\begin{array}{l}95, \mathrm{df}=1 \\
=8.25(\mathrm{P}=\end{array}$ & $\begin{array}{l}(P=0 . \\
0.0000\end{array}$ & $12) ;\left.\right|^{2}=$ & $29 \%$ & & & 0.005 & $\begin{array}{c}0.1 \\
\text { urs co }\end{array}$ & $1 \frac{10}{\text { Favours }}$ \\
\hline
\end{tabular}

Figure 3.

Forest plot of comparison: 1 Treatment vs control (headache) post-treatment, outcome: 1.1 Pain. 
Percent with $\geq 50 \%$ improvement with treatment

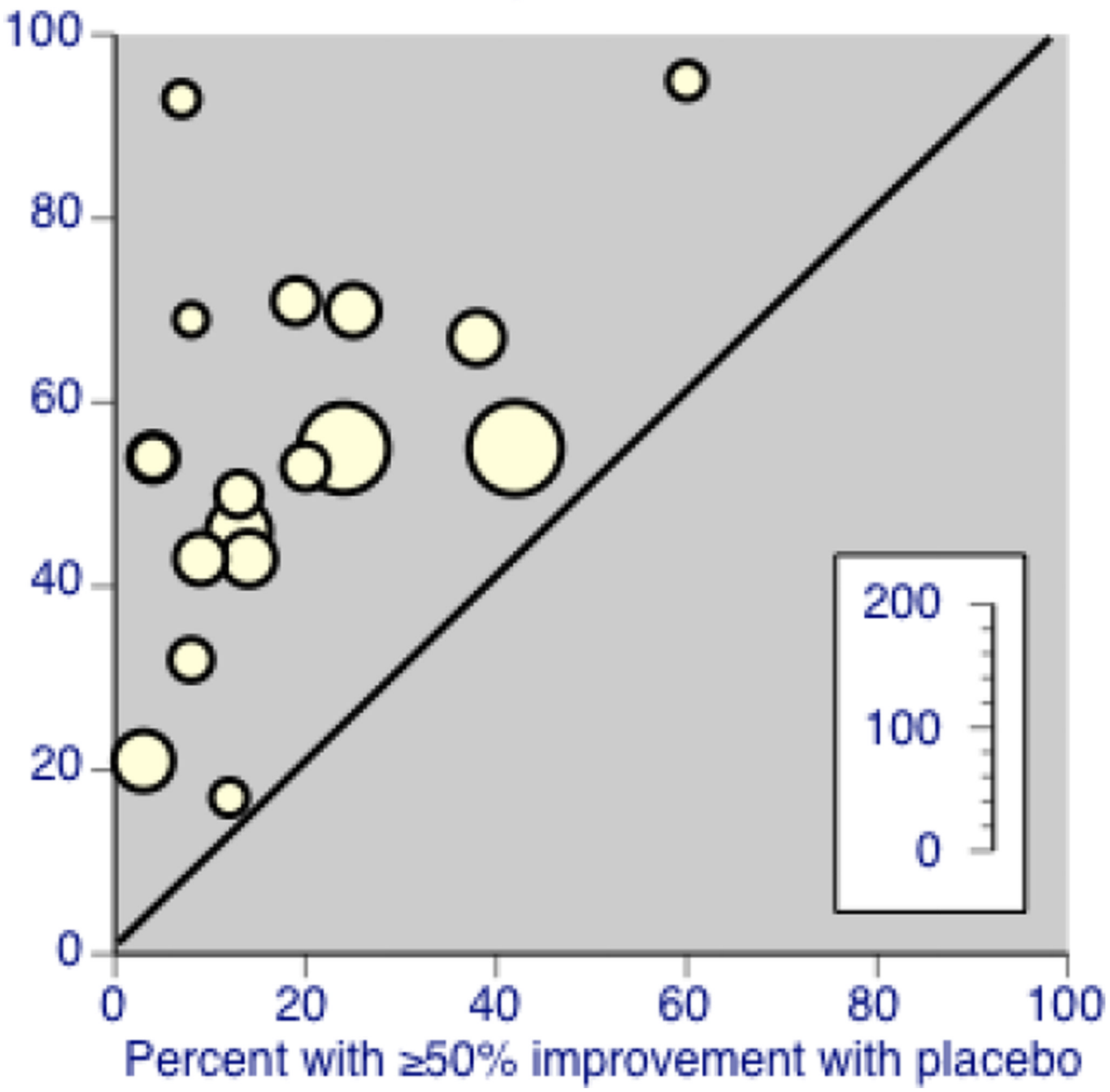

Figure 4. 


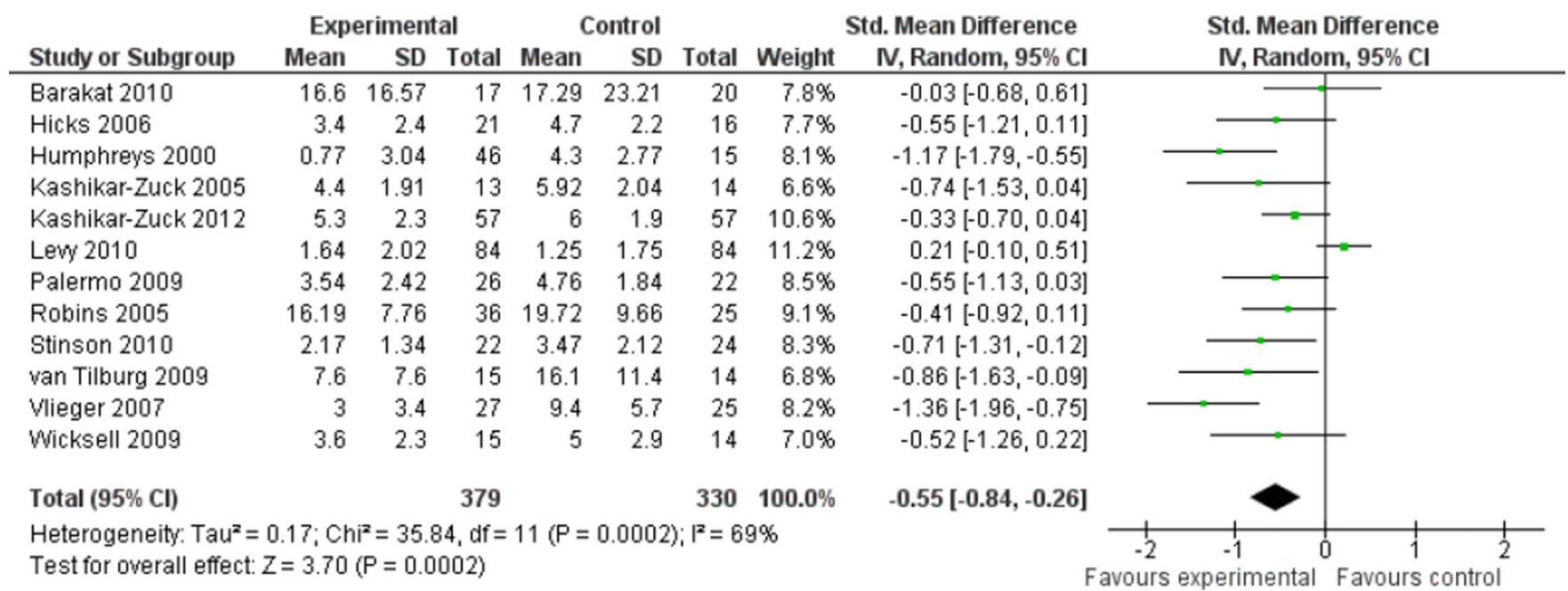

Figure 5.

Forest plot of comparison: 3 Treatment vs control (non-headache) post-treatment, outcome: 3.1 Pain. 


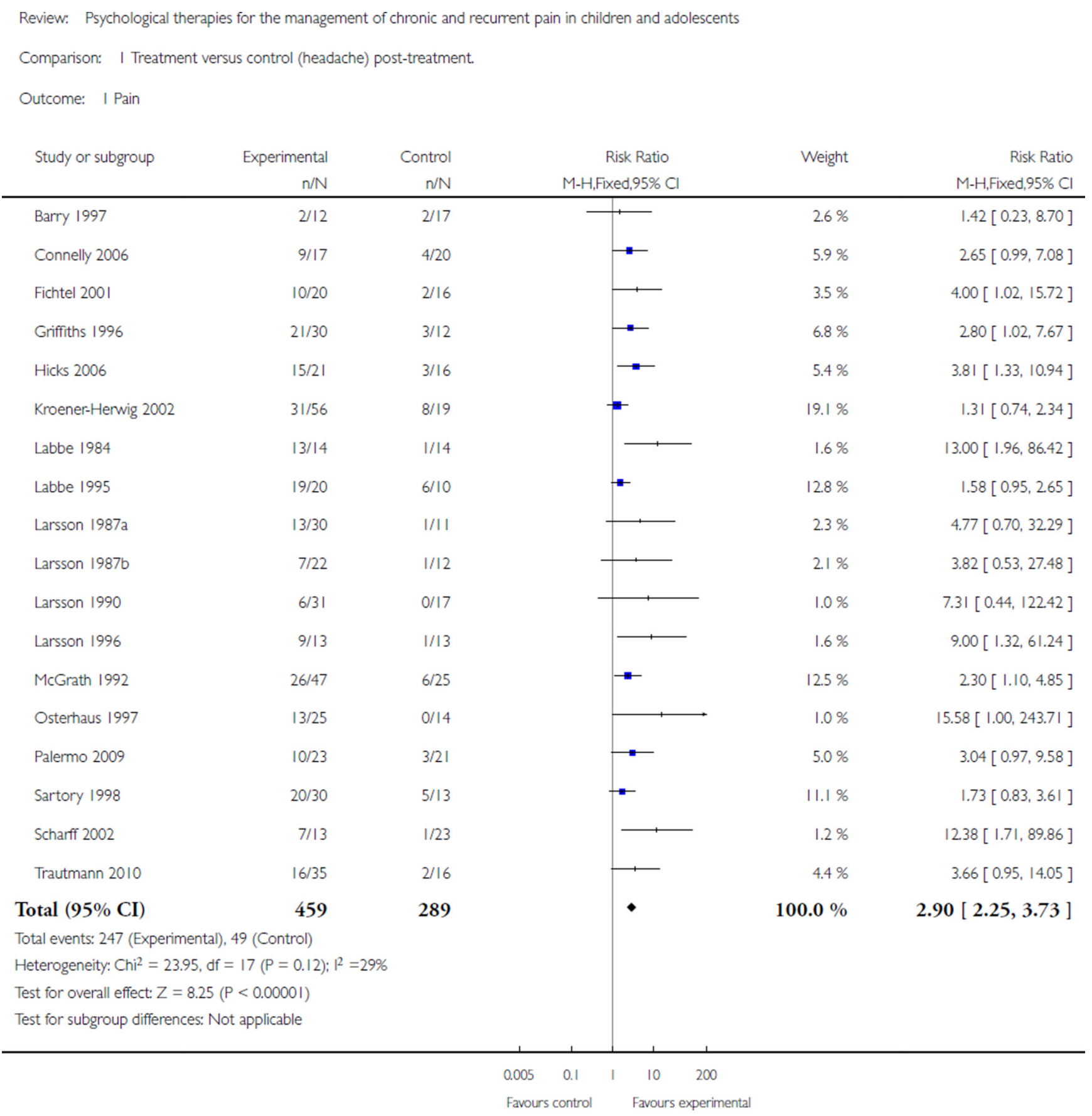

Analysis 1.1.

Comparison 1 Treatment versus control (headache) post-treatment., Outcome 1 Pain. 


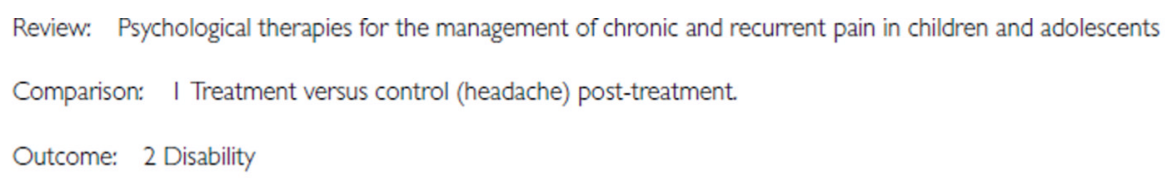

\begin{tabular}{|c|c|c|c|c|c|c|c|}
\hline \multirow[t]{2}{*}{ Study or subgroup } & \multirow{2}{*}{$\begin{array}{r}\text { Experimental } \\
\mathrm{N}\end{array}$} & \multicolumn{2}{|c|}{ Control } & \multicolumn{2}{|r|}{$\begin{array}{r}\text { Std. } \\
\text { Mean } \\
\text { Difference }\end{array}$} & \multirow[t]{2}{*}{ Weight } & \multirow{2}{*}{$\begin{array}{r}\text { Std. } \\
\text { Mean } \\
\text { Difference } \\
\text { IV,Random, } 95 \% \mathrm{Cl}\end{array}$} \\
\hline & & Mean(SD) & $N$ & Mean(SD) & IV,Random, $95 \% \mathrm{Cl}$ & & \\
\hline Connelly 2006 & 14 & $12.2(9.92)$ & 17 & $10.74(\mid 1.61)$ & $\longrightarrow$ & $31.6 \%$ & $0.13[-0.58,0.84]$ \\
\hline Palermo 2009 & 26 & $3.6(2.86)$ & 22 & $6.62(4.76)$ & —- & $37.8 \%$ & $-0.77[-1.36,-0.18]$ \\
\hline Wicksell 2009 & 15 & $12.3(13.9)$ & 14 & $14.6(11.3)$ & + & $30.6 \%$ & $-0.18[-0.91,0.55]$ \\
\hline Total $(95 \% \mathrm{CI})$ & 55 & & 53 & & & $100.0 \%$ & $-0.30[-0.85,0.24]$ \\
\hline \multicolumn{8}{|c|}{ Heterogeneity: $\operatorname{Ta}^{2}=0.12 ; \mathrm{Chi}^{2}=3.95, \mathrm{df}=2(\mathrm{P}=0.14) ; \mathrm{I}^{2}=49 \%$} \\
\hline \multicolumn{8}{|c|}{ Test for overall effect: $Z=1.09(P=0.28)$} \\
\hline \multicolumn{8}{|c|}{ Test for subgroup differences: Not applicable } \\
\hline
\end{tabular}

Analysis 1.2.

Comparison 1 Treatment versus control (headache) post-treatment., Outcome 2 Disability. 


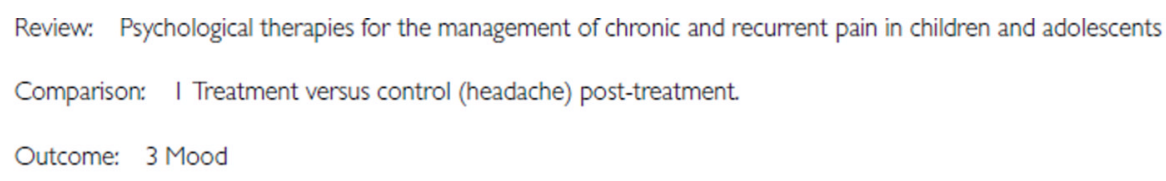

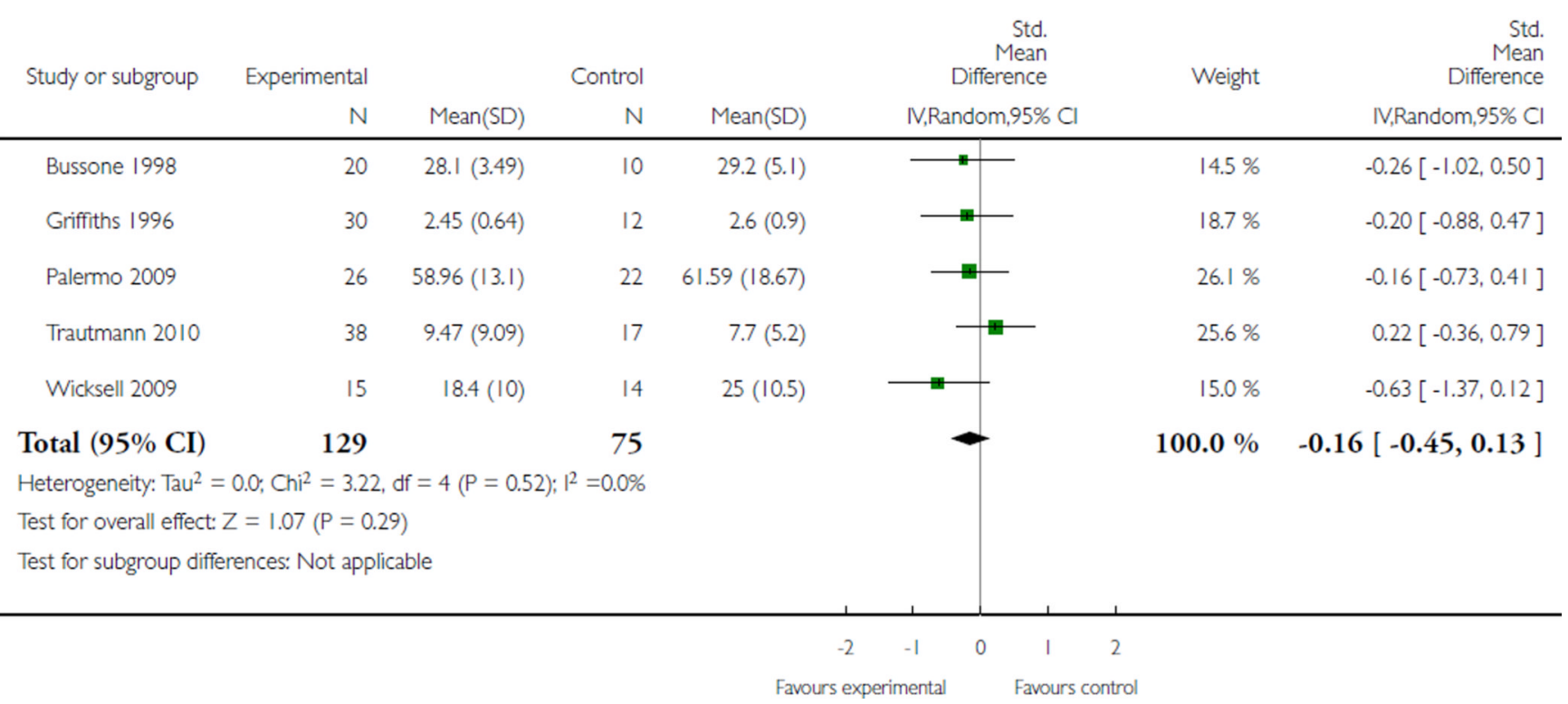

Analysis 1.3.

Comparison 1 Treatment versus control (headache) post-treatment., Outcome 3 Mood. 


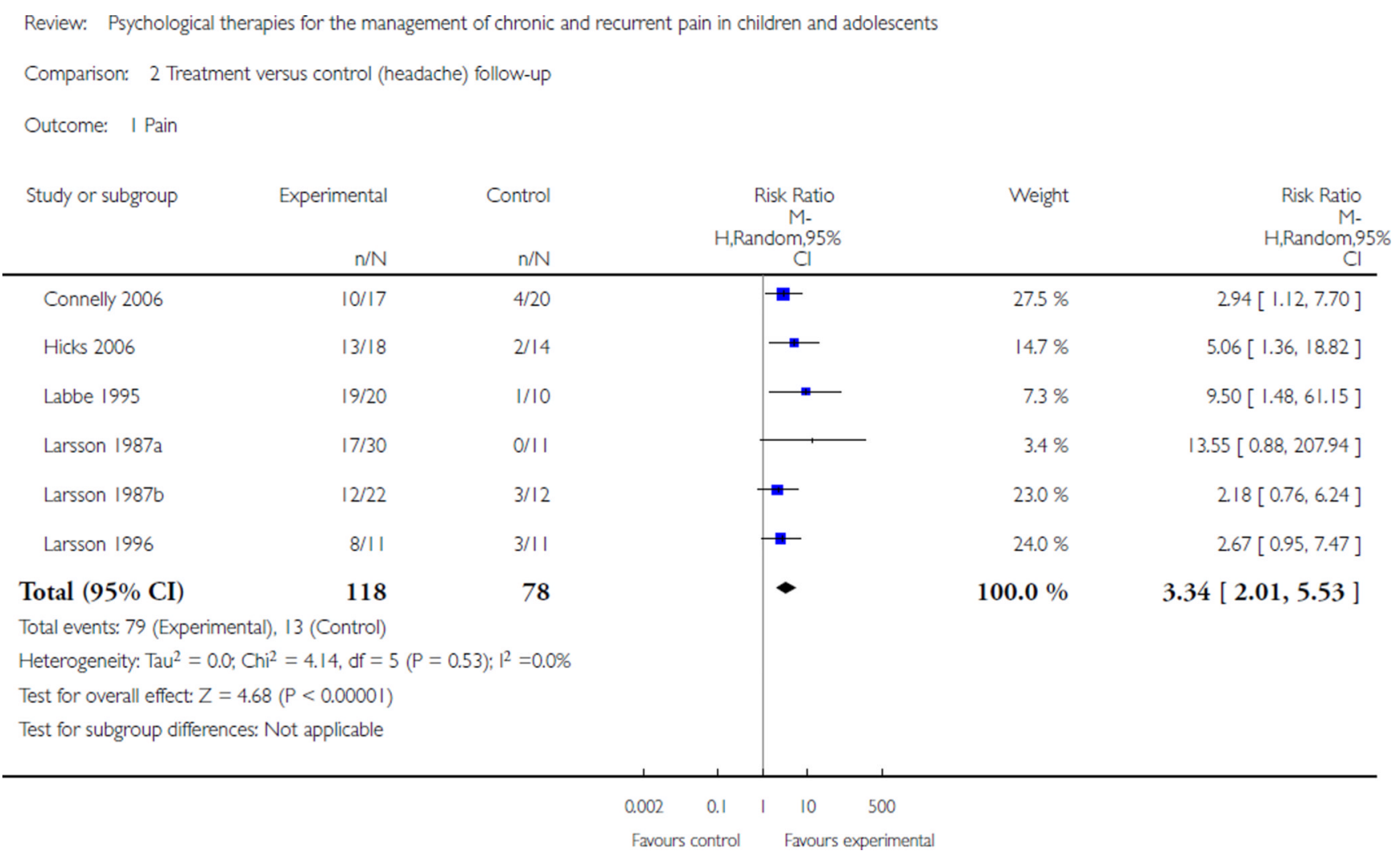

\section{Analysis 2.1.}

Comparison 2 Treatment versus control (headache) follow-up, Outcome 1 Pain. 


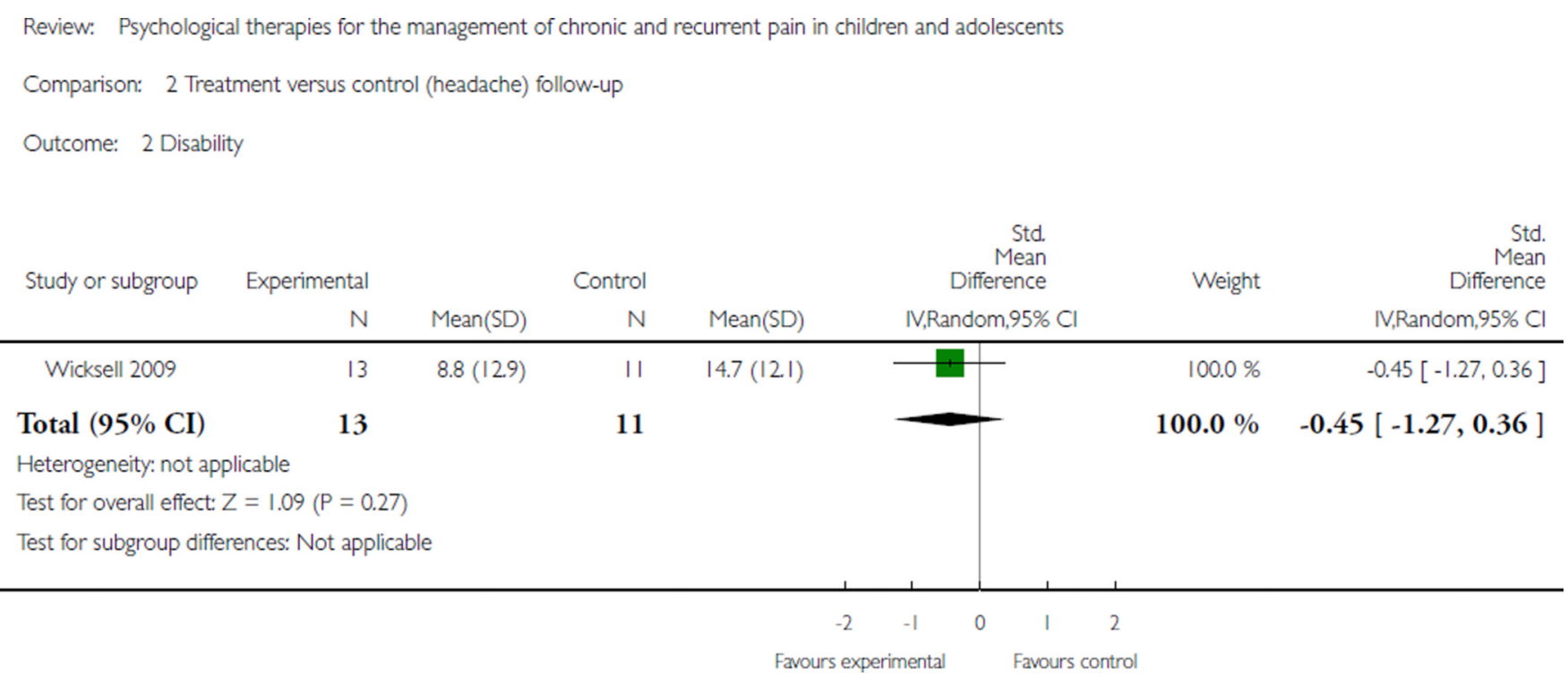

Analysis 2.2.

Comparison 2 Treatment versus control (headache) follow-up, Outcome 2 Disability. 


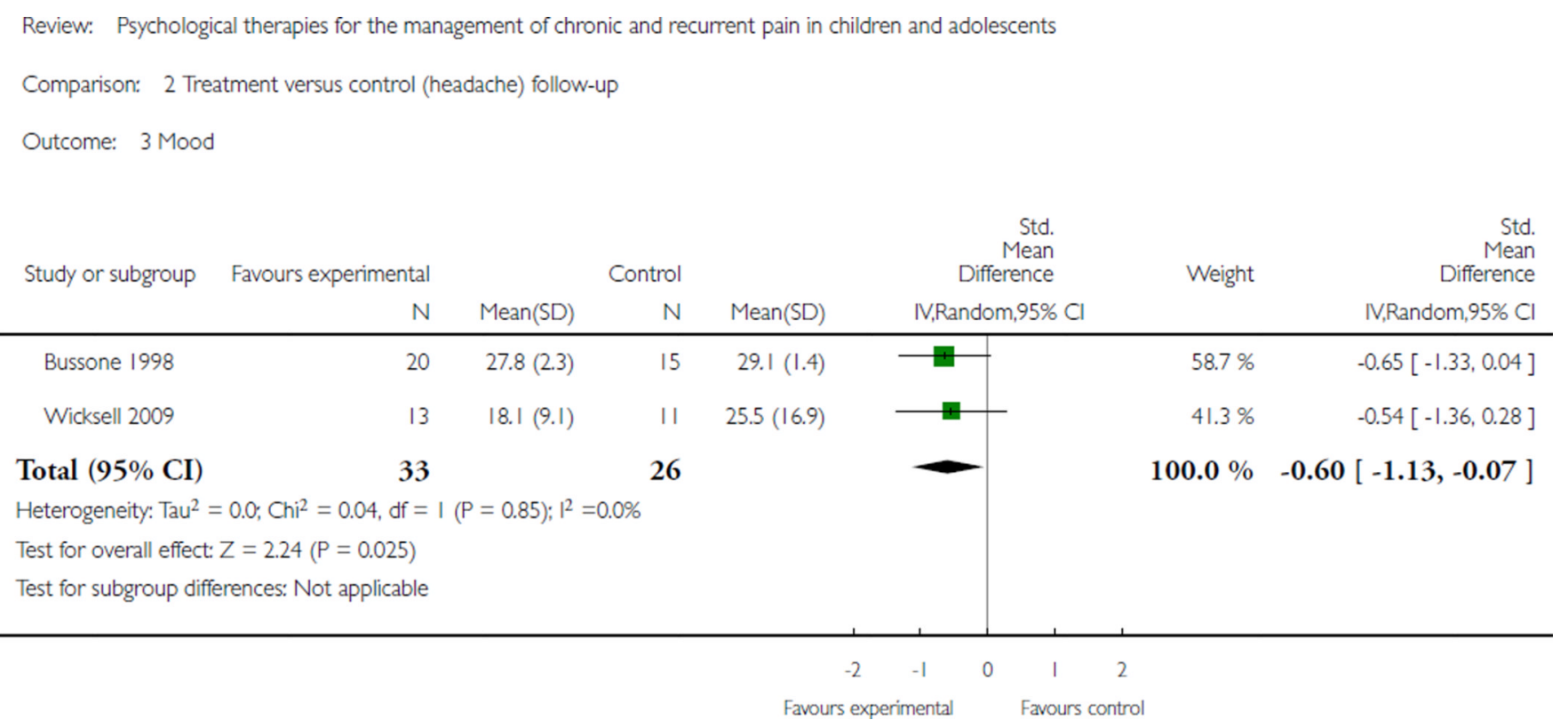

Analysis 2.3.

Comparison 2 Treatment versus control (headache) follow-up, Outcome 3 Mood. 
Review: Psychological therapies for the management of chronic and recurrent pain in children and adolescents

Comparison: 3 Treatment versus control (non-headache) post-treatment

Outcome: I Pain

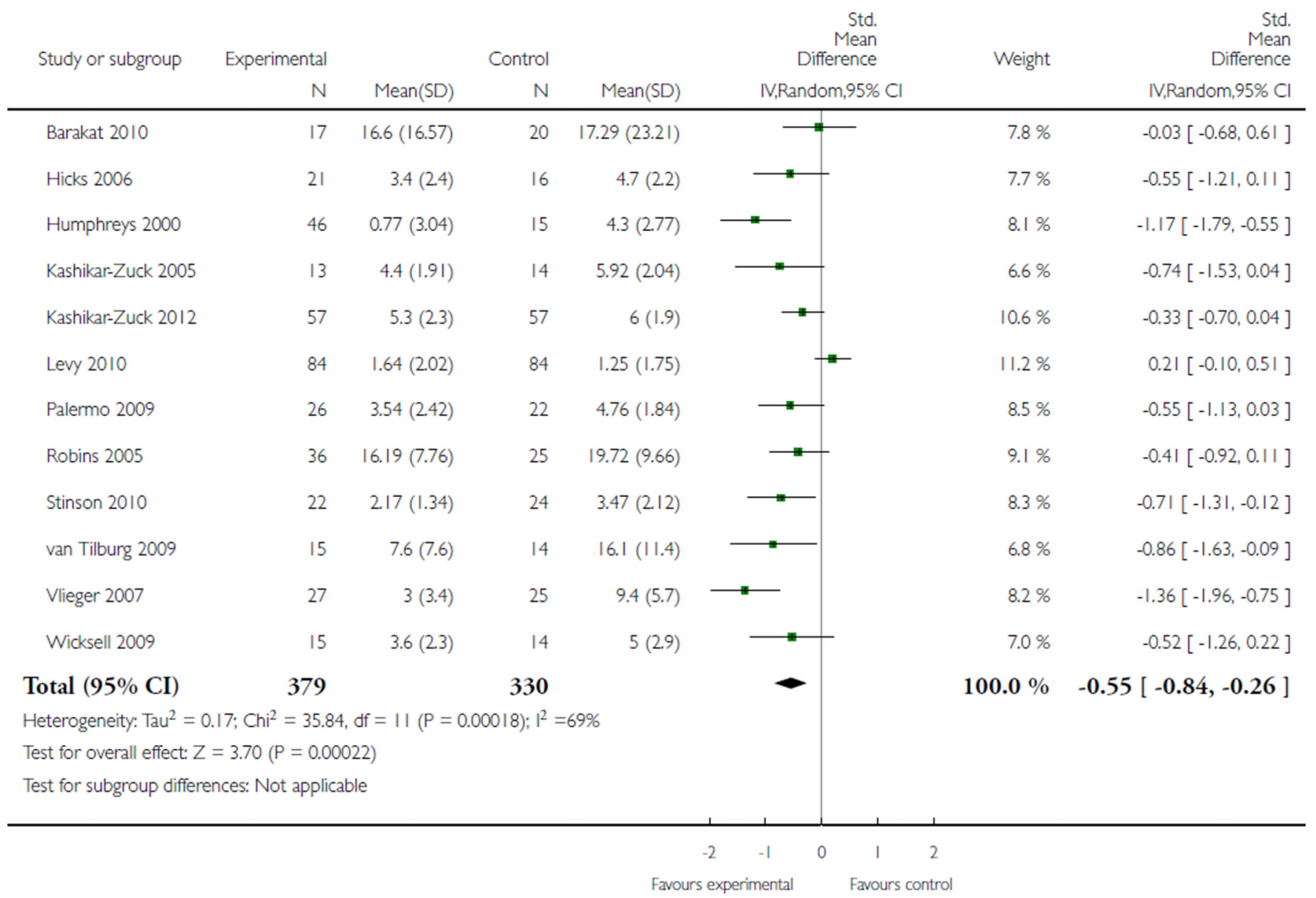

Analysis 3.1.

Comparison 3 Treatment versus control (non-headache) post-treatment, Outcome 1 Pain. 


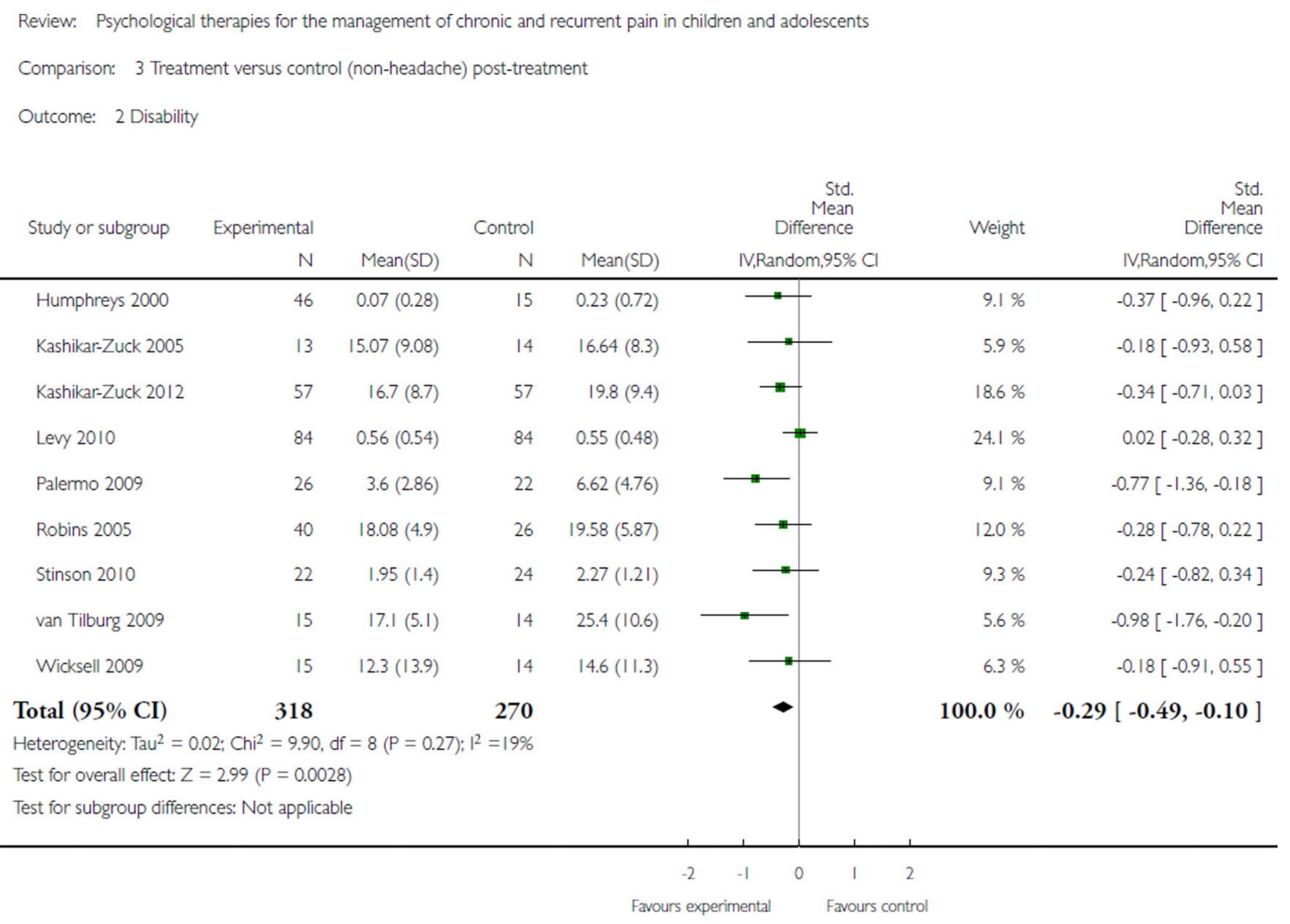

\section{Analysis 3.2.}

Comparison 3 Treatment versus control (non-headache) post-treatment, Outcome 2 Disability. 


\begin{tabular}{|c|c|c|c|c|c|c|c|}
\hline \multicolumn{8}{|c|}{ Comparison: 3 Treatment versus control (non-headache) post-treatment } \\
\hline Outcome: 3 Mood & & & & & & & \\
\hline \multirow[t]{2}{*}{ Study or subgroup } & \multirow{2}{*}{$\begin{array}{r}\text { Experimental } \\
\mathrm{N}\end{array}$} & \multicolumn{3}{|c|}{ Control } & \multirow{2}{*}{$\begin{array}{c}\text { Std. } \\
\text { Mean } \\
\text { Difference } \\
\text { IV,Random, } 95 \% \mathrm{Cl}\end{array}$} & \multirow[t]{2}{*}{ Weight } & \multirow{2}{*}{$\begin{array}{r}\text { Std } \\
\text { Mean } \\
\text { Difference } \\
\text { IV,Random,95\% Cl }\end{array}$} \\
\hline & & Mean(SD) & $\mathrm{N}$ & Mean(SD) & & & \\
\hline Kashikar-Zuck 2005 & 15 & $49.57(17.6)$ & 15 & $48.46(12.89)$ & $\Psi$ & $11.2 \%$ & $0.07[-0.65,0.79]$ \\
\hline Kashikar-Zuck 2012 & 57 & $9.9(6.2)$ & 57 & $11.8(5.8)$ & 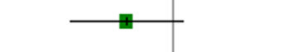 & $22.8 \%$ & $-0.31[-0.68,0.06]$ \\
\hline Levy 2010 & 84 & $9.96(6.16)$ & 84 & $8.35(5.73)$ & 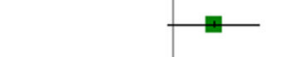 & $25.9 \%$ & $0.27[-0.03,0.57]$ \\
\hline Palermo 2009 & 26 & $58.96(13.1)$ & 22 & $61.59(18.67)$ & 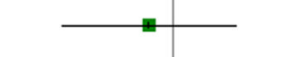 & $15.0 \%$ & $-0.16[-0.73,0.41]$ \\
\hline Stinson 2010 & 22 & $1.98(0.42)$ & 24 & $2.13(0.42)$ & & $14.6 \%$ & $-0.35[-0.93,0.23]$ \\
\hline Wicksell 2009 & 15 & $18.4(10)$ & 14 & $25(10.5)$ & $\longleftarrow$ & $10.5 \%$ & $-0.63[-1.37,0.12]$ \\
\hline Total $(95 \%$ CI $)$ & 219 & & 216 & & - & $100.0 \%$ & $-0.14[-0.42,0.15]$ \\
\hline \multicolumn{8}{|c|}{ Heterogeneity: $\mathrm{Tau}^{2}=0.06 ; \mathrm{Chi}^{2}=9.73, \mathrm{df}=5(\mathrm{P}=0.08) ; \mathrm{I}^{2}=49 \%$} \\
\hline \multicolumn{8}{|c|}{ Test for overall effect: $Z=0.92(P=0.36)$} \\
\hline \multicolumn{8}{|c|}{ Test for subgroup differences: Not applicable } \\
\hline
\end{tabular}

\section{Analysis 3.3.}

Comparison 3 Treatment versus control (non-headache) post-treatment, Outcome 3 Mood. 


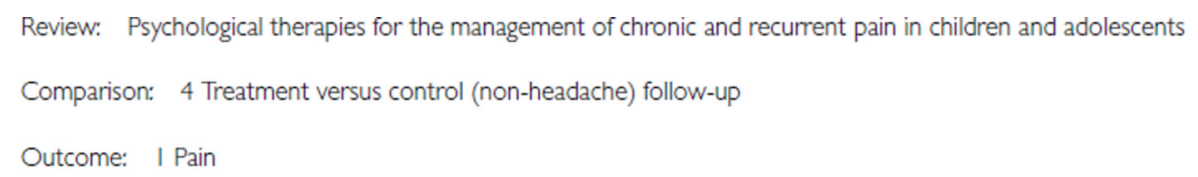

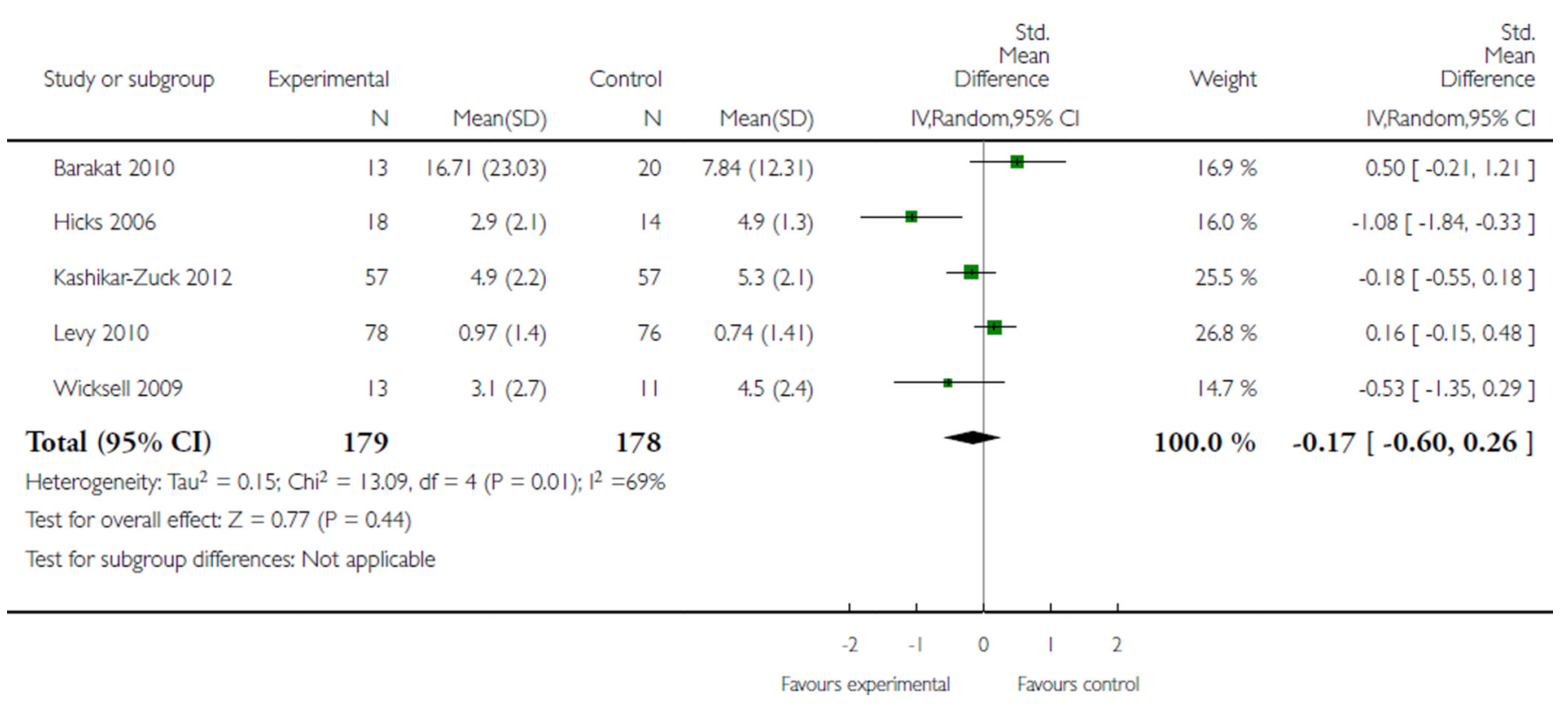

Analysis 4.1.

Comparison 4 Treatment versus control (non-headache) follow-up, Outcome 1 Pain. 


\begin{tabular}{|c|c|c|c|c|c|c|c|}
\hline \multicolumn{8}{|c|}{ Comparison: 4 Treatment versus control (non-headache) follow-up } \\
\hline Outcome: 2 Disability & & & & & \multirow{3}{*}{$\begin{array}{c}\text { Std. } \\
\text { Mean } \\
\text { Difference } \\
\text { IV,Random, } 95 \% \mathrm{Cl}\end{array}$} & & \\
\hline \multirow[t]{2}{*}{ Study or subgroup } & \multirow{2}{*}{$\begin{array}{r}\text { Experimental } \\
\mathrm{N}\end{array}$} & \multicolumn{3}{|c|}{ Control } & & \multirow[t]{2}{*}{ Weight } & \multirow{2}{*}{$\begin{array}{r}\text { Std. } \\
\text { Mean } \\
\text { Difference } \\
\text { IV,Random, } 95 \% \mathrm{Cl}\end{array}$} \\
\hline & & $\operatorname{Mean}(\mathrm{SD})$ & N & Mean(SD) & & & \\
\hline Kashikar-Zuck 2012 & 57 & $13.4(8.9)$ & 57 & $17(10.5)$ & $\div$ & $40.0 \%$ & $-0.37[-0.74,0.00]$ \\
\hline Levy 2010 & 78 & $0.44(0.5 \mathrm{I})$ & 76 & $0.42(0.42)$ & & $46.8 \%$ & $0.04[-0.27,0.36]$ \\
\hline Wicksell 2009 & 13 & $8.8(12.9)$ & 11 & $14.7(12.1)$ & \begin{tabular}{l|l} 
\pm-1 \\
& -1
\end{tabular} & $13.2 \%$ & $-0.45[-1.27,0.36]$ \\
\hline Total $(95 \% \mathrm{CI})$ & 148 & & 144 & & & $100.0 \%$ & $-0.19[-0.51,0.13]$ \\
\hline \multicolumn{8}{|c|}{ Heterogeneity: $\mathrm{Tau}^{2}=0.03 ; \mathrm{Chi}^{2}=3.28, \mathrm{df}=2(\mathrm{P}=0.19) ; 1^{2}=39 \%$} \\
\hline \multicolumn{8}{|c|}{ Test for overall effect: $Z=1.14(P=0.25)$} \\
\hline \multicolumn{8}{|c|}{ Test for subgroup differences: Not applicable } \\
\hline
\end{tabular}

Analysis 4.2.

Comparison 4 Treatment versus control (non-headache) follow-up, Outcome 2 Disability. 


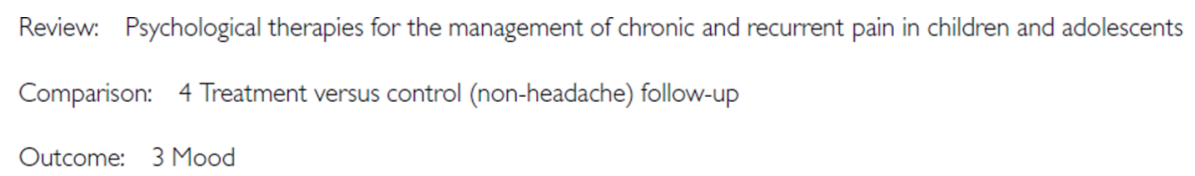

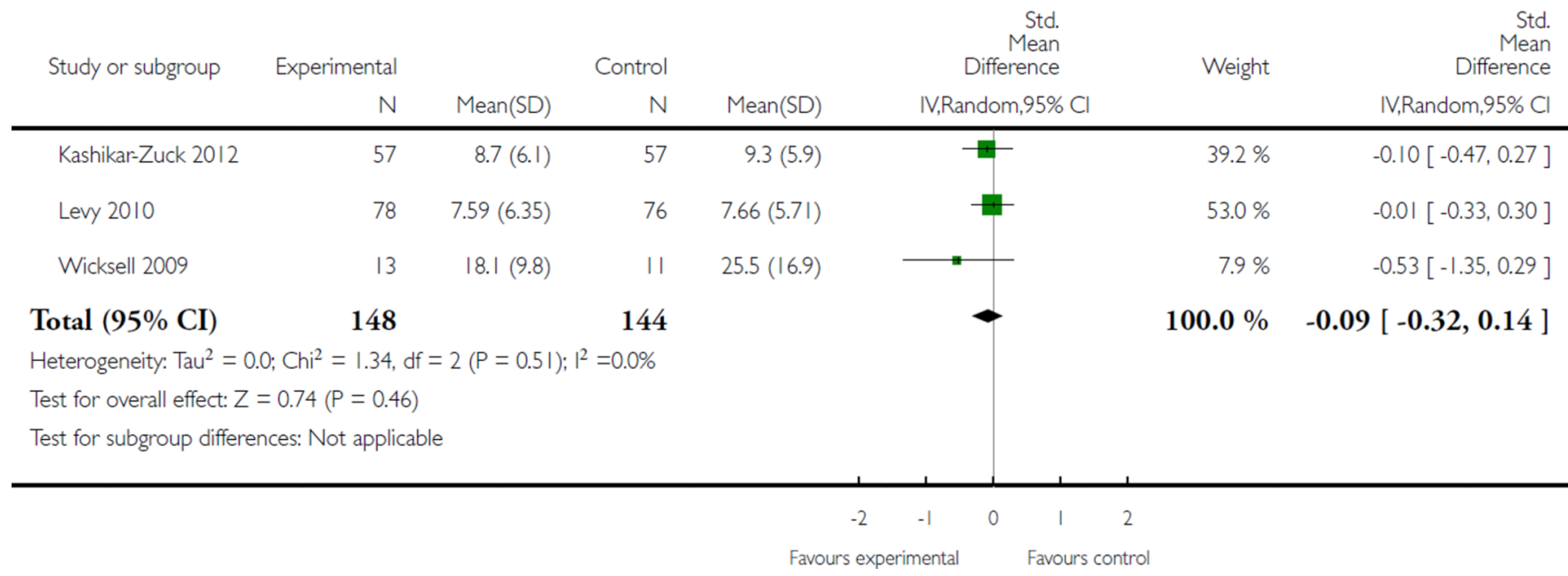

Analysis 4.3.

Comparison 4 Treatment versus control (non-headache) follow-up, Outcome 3 Mood. 
Table 1

Duration of treatment and setting by condition

\begin{tabular}{|c|c|c|c|}
\hline \multicolumn{4}{|l|}{ Headache studies } \\
\hline Author & Illness & Treatment duration (Hrs) & Setting \\
\hline Abram 2007 & Headache & 1.5 & Clinic \\
\hline Barry 1997 & Headache & 3 & Unknown \\
\hline Bussone 1998 & Headache & 7 & Clinic \\
\hline Connelly 2006 & Headache & Unknown & Home - CDROM \\
\hline Fichtel 2001 & Headache & 6.75 & Clinic \\
\hline Griffiths 1996 & Headache & 12 & Clinic/Home \\
\hline Hicks $2006^{*}$ & Mixed & Unknown & Home - Internet \\
\hline Kroener-Herwig 2002 & Headache & 12 & Clinic \\
\hline Labbe 1984 & Headache & 6.7 & Clinic \\
\hline Labbe 1995 & Headache & 7.5 & Clinic \\
\hline Larsson 1987a & Headache & 6.75 & School \\
\hline Larsson $1987 b$ & Headache & 5 & School \\
\hline Larsson 1990 & Headache & 1.7 & Home \\
\hline Larsson 1996 & Headache & 3.3 & Clinic \\
\hline McGrath 1988 & Headache & 6 & Unknown \\
\hline McGrath 1992 & Headache & 8 & Home/Clinic \\
\hline Osterhaus 1997 & Headache & 9.3 & Clinic \\
\hline Palermo $2009^{*}$ & Mixed & 4 & Home - Internet \\
\hline Passchier 1990 & Headache & 2.5 & School \\
\hline Richter 1986 & Headache & 9 & Unknown \\
\hline Sartory 1998 & Headache & Unknown & Clinic \\
\hline Scharff 2002 & Headache & 4 & Clinic \\
\hline Trautmann 2010 & Headache & Unknown & Home - Internet \\
\hline Wicksell 2009* & Mixed & 10 & Clinic \\
\hline
\end{tabular}

Non-headache studies

\begin{tabular}{l|l|l|l}
\hline Author & Illness & Treatment duration (Hrs) & Setting \\
\hline Alfven 2007 & RAP & Unknown & Clinic \\
\hline Barakat 2010 & SCD & 6 & Home \\
\hline Duarte 2006 & RAP & 3.3 & Unknown \\
\hline Gil 1997 & SCD & 0.75 & Clinic \\
\hline Hicks 2006* & Headache + RAP & Unknown & Home - Internet \\
\hline Humphreys 2000 & RAP & Unknown & Clinic \\
\hline Kashikar-Zuck 2005 & Fibromyalgia & Unknown & Clinic \\
\hline Kashikar-Zuck 2012 & Fibromyalgia & 6 & Unknown \\
\hline Levy 2010 & RAP & 4 & Home/Clinic \\
\hline
\end{tabular}


Non-headache studies

\begin{tabular}{l|l|l|l}
\hline Author & Illness & Treatment duration $($ Hrs $)$ & Setting \\
\hline Palermo 2009* & Mixed & 4 & Home - Internet \\
\hline Robins 2005 & RAP & 3.5 & Clinic \\
\hline Sanders 1994 & RAP & 6 & Clinic \\
\hline Stinson 2010 & JIA & 5 & Home - Internet \\
\hline an Tilburg 2009 & RAP & 1.8 & Home \\
\hline Vlieger 2007 & RAP/IBS & 5 & Clinic \\
\hline Wicksell 2009* & Mixed & 10 & Clinic \\
\hline
\end{tabular}

Mixed headache and non-headache studies are entered twice. Recurrent abdominal pain (RAP), Sickle cell disease (SCD), Juvenile idiopathic arthritis (JIA), Irritable bowel syndrome (IBS). 


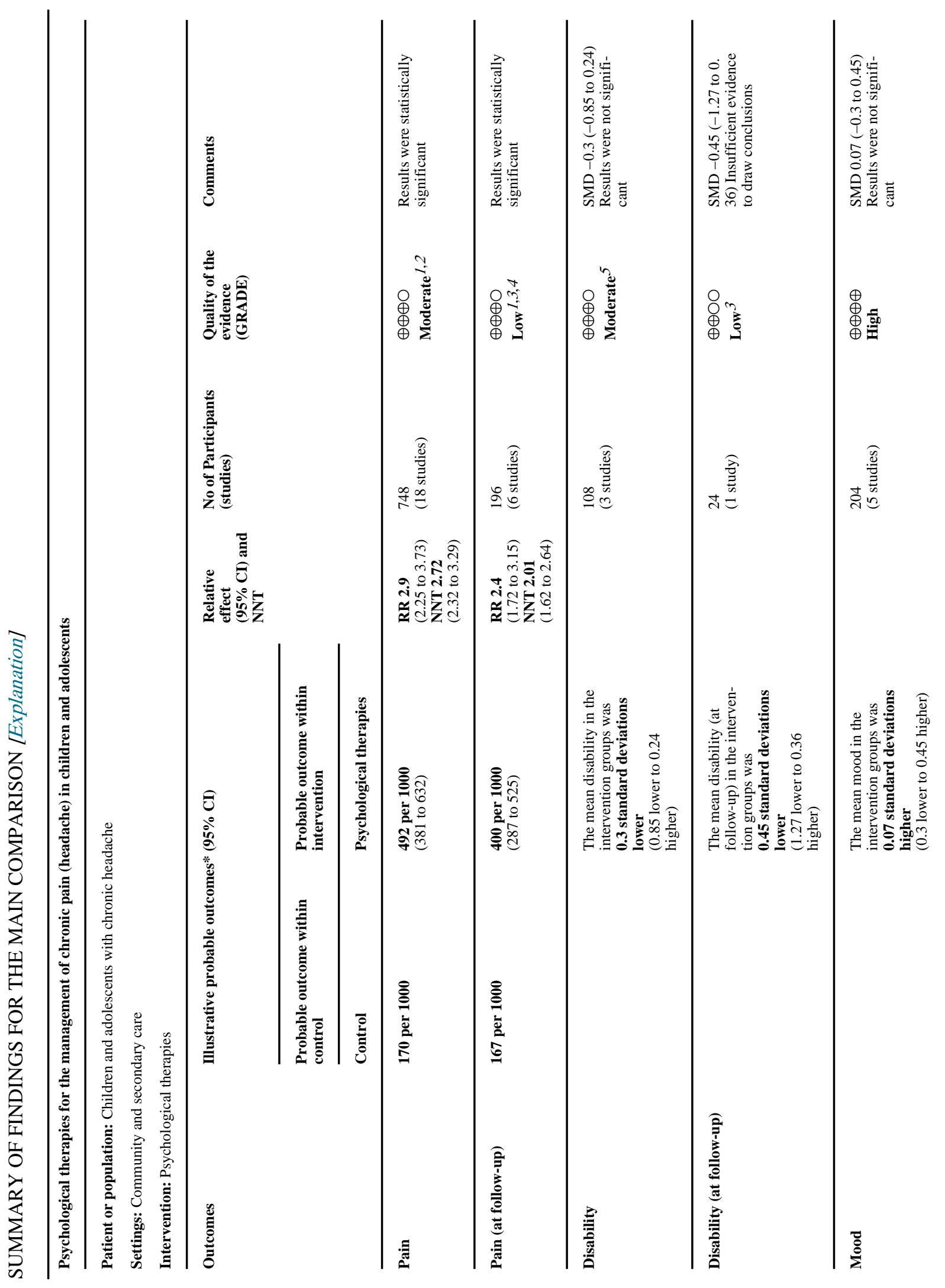




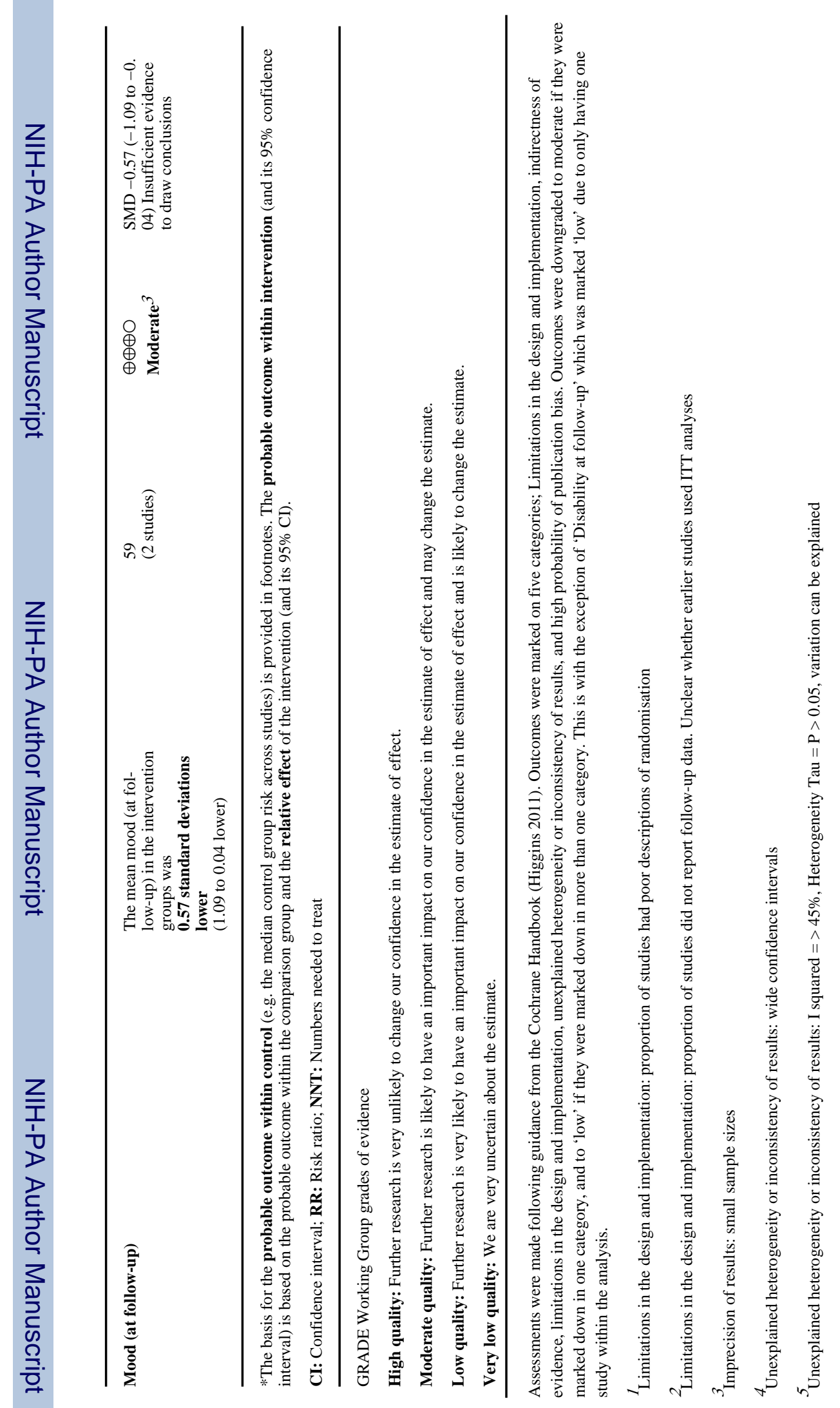

Cochrane Database Syst Rev. Author manuscript; available in PMC 2013 December 12. 


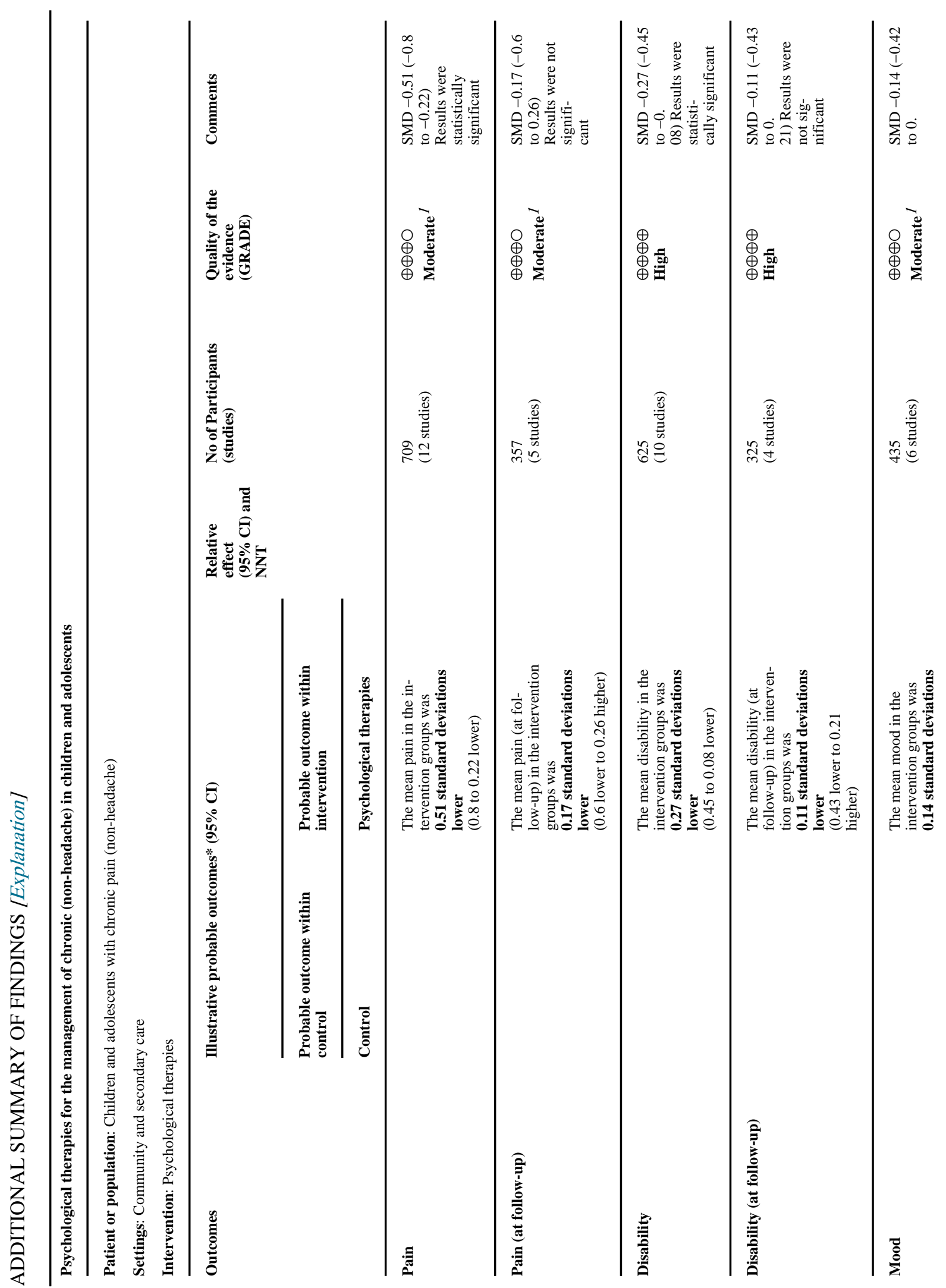




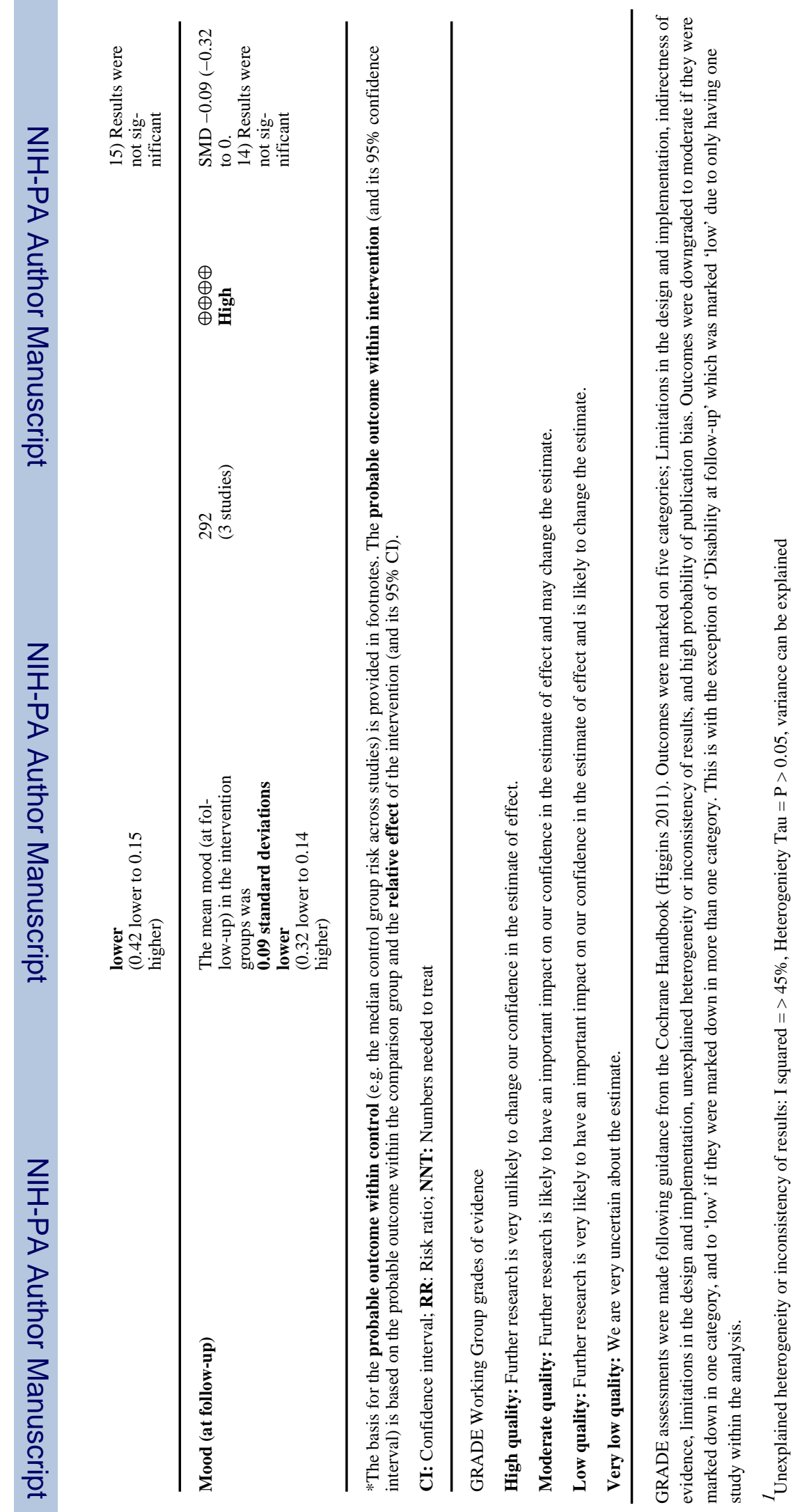

Cochrane Database Syst Rev. Author manuscript; available in PMC 2013 December 12. 


\section{CHARACTERISTICS OF STUDIES}

Characteristics of included studies [ordered by study ID]

\begin{tabular}{|c|c|c|}
\hline Methods & \multicolumn{2}{|c|}{$\begin{array}{l}\text { RCT. Two arms. Assessed at pre-treatment, post-treatment (three month follow-up), six } \\
\text { months }\end{array}$} \\
\hline Participants & \multicolumn{2}{|c|}{$\begin{array}{l}\text { End of treatment } \mathrm{n}=50 \\
\text { Start of treatment } \mathrm{n}=81 \\
\text { Sex: } 45 \mathrm{~F}, 36 \mathrm{M} \\
\text { Mean age }=12.7 \text { (range 10-18) } \\
\text { Source = Hospital and Clinic } \\
\text { Diagnosis = Headache } \\
\text { Mean years of pain = not given }\end{array}$} \\
\hline Interventions & \multicolumn{2}{|c|}{$\begin{array}{l}\text { "Headache Clinical Model: behavioural intervention" } \\
\text { "Headache Traditional Model: consultation with neurologist" }\end{array}$} \\
\hline Outcomes & \multicolumn{2}{|c|}{$\begin{array}{l}\text { Primary Pain Outcome: none } \\
\text { Primary Disability Outcome: Ped-MIDAS } \\
\text { Primary Mood Outcome: none } \\
\text { 1. Pediatric Migraine Disability Assessment (Ped-MIDAS) } \\
\text { 2. FDI-C } \\
\text { 3. Headache Knowledge test } \\
\text { 4. Use of Healthcare measure }\end{array}$} \\
\hline Notes & \multicolumn{2}{|l|}{$\begin{array}{l}\text { Updated Study } 2009 \\
\text { Total Quality = 22/35 } \\
\text { Treatment Quality = 7/9 } \\
\text { Design Quality = 15/26 }\end{array}$} \\
\hline \multicolumn{3}{|l|}{ Risk of bias } \\
\hline Bias & Authors' judgement & Support for judgement \\
\hline $\begin{array}{l}\text { Random sequence generation (selection } \\
\text { bias) }\end{array}$ & Low risk & $\begin{array}{l}\text { 'If the family was interested in the study, } \\
\text { they were randomised (using a random } \\
\text { number table) to either a TCM appoint- } \\
\text { ment or a HCM appointment.' Comment: } \\
\text { Probably done }\end{array}$ \\
\hline Allocation concealment (selection bias) & Unclear risk & $\begin{array}{l}\text { No description found in text. Comment: } \\
\text { Probably not done. }\end{array}$ \\
\hline $\begin{array}{l}\text { Blinding of outcome assessment (detection } \\
\text { bias) } \\
\text { All outcomes }\end{array}$ & Unclear risk & $\begin{array}{l}\text { No description found in text. Comment: } \\
\text { Probably not done. }\end{array}$ \\
\hline $\begin{array}{l}\text { Incomplete outcome data (attrition bias) } \\
\text { All outcomes }\end{array}$ & Unclear risk & $\begin{array}{l}\text { Attrition is described, however no signifi- } \\
\text { cant descriptions between completers and } \\
\text { non-completers were reported }\end{array}$ \\
\hline Selective reporting (reporting bias) & High risk & Data were incompletely reported. \\
\hline
\end{tabular}


Alfven 2007

\begin{tabular}{|c|c|}
\hline Methods & RCT. Two arms. Assessed at pre-treatment and one-year follow-up \\
\hline Participants & $\begin{array}{l}\text { End of treatment } \mathrm{n}=48 \\
\text { Start of treatment } \mathrm{n}=48 \\
\text { Sex: } 61 \mathrm{~F}, 22 \mathrm{M} \text { (Of entire sample in three treatment conditions, one post randomisation) } \\
\text { Mean age }=9.9 \text { (range 6-18) } \\
\text { Source = Hospital } \\
\text { Diagnosis = Recurrent Abdominal Pain } \\
\text { Mean years of pain }=2.5\end{array}$ \\
\hline Interventions & $\begin{array}{l}\text { "psychological treatment and physiotherapy" } \\
\text { "Physiotherapy alone" }\end{array}$ \\
\hline Outcomes & $\begin{array}{l}\text { Primary Pain Outcome: Pain score } \\
\text { Primary Disability Outcome: none } \\
\text { Primary Mood Outcome: none } \\
\text { 1. Pain intensity (VAS) } \\
\text { 2. Pain Score } \\
\text { a) frequency } \\
\text { b) intensity } \\
\text { c) duration } \\
\text { 3. Tender points (algometer) }\end{array}$ \\
\hline Notes & $\begin{array}{l}\text { Updated Study } 2009 \\
\text { Total Quality = 13/35 } \\
\text { Treatment Quality = 2/9 } \\
\text { Design Quality = 11/26 }\end{array}$ \\
\hline
\end{tabular}

Risk of bias

\begin{tabular}{l|l|l}
\hline Bias & Authors' judgement & Support for judgement \\
\hline $\begin{array}{l}\text { Random sequence generation (selection } \\
\text { bias) }\end{array}$ & Unclear risk & $\begin{array}{l}\text { 'The children recruited during 1996-1999 } \\
\text { were randomised'. Comment: probably } \\
\text { done, method not described }\end{array}$ \\
\hline $\begin{array}{l}\text { Allocation concealment (selection bias) } \\
\begin{array}{l}\text { Blinding of outcome assessment (detection } \\
\text { bias) }\end{array}\end{array}$ & Unclear risk & $\begin{array}{l}\text { No description found in text. Comment: } \\
\text { Probably not done. }\end{array}$ \\
\hline $\begin{array}{l}\text { Incomplete outcome data (attrition bias) } \\
\text { All outcomes }\end{array}$ & Low risk & $\begin{array}{l}\text { No description found in text. Comment: } \\
\text { Probably not done. }\end{array}$ \\
\hline \begin{tabular}{l} 
Selective reporting (reporting bias) \\
\hline
\end{tabular} & High risk & No dropouts reported. \\
\hline
\end{tabular}

Barakat 2010

\begin{tabular}{l|l}
\hline Methods & RCT. Two arms. Assessed at pre-treatment, post-treatment and twelve months
\end{tabular}


Barakat 2010

Participants

End of treatment $n=42$, Follow-up 1 year $n=34$

Start of treatment $n=42$

Sex: $12 \mathrm{~F}, 15 \mathrm{M}$

Mean age $=14.17(1.75)$

Source $=$ Sickle cell centre

Diagnosis $=$ Sickle Cell Disease

Mean years of pain $=$ Lifetime

\begin{tabular}{l|l}
\hline Interventions & $\begin{array}{l}\text { "Pain Management Intervention" } \\
\text { "Disease Education Intervention" }\end{array}$ \\
\hline Outcomes & $\begin{array}{l}\text { Primary Pain Outcome: Pain Diary } \\
\text { Primary Disability Outcome: none } \\
\text { Primary Mood Outcome: none }\end{array}$ \\
& $\begin{array}{l}\text { 1. Pain Diary } \\
\text { 2. Health-related Hindrance Inventory } \\
\text { 3. Child Health Questionnaire }\end{array}$ \\
& 4. Family Cohesion Scale \\
& 5. Disease Self-efficacy Scale \\
& 6. Coping Strategies Inventory \\
& 7. SCD Transition Knowledge Questionnaire \\
& 8. Medical Chart Review \\
& 9. School Attendance \\
\hline \multirow{2}{*}{ Notes } & Updated study 2012 \\
& Total Quality = 27/35 \\
& Treatment Quality = 9/9 \\
& Design Quality = 18/26 \\
\hline
\end{tabular}

Risk of bias

\begin{tabular}{l|l|l}
\hline Bias & Authors' judgement & Support for judgement \\
\hline $\begin{array}{l}\text { Random sequence generation (selection } \\
\text { bias) }\end{array}$ & Unclear risk & $\begin{array}{l}\text { 'A 2-group, randomized treatment de- } \\
\text { sign was used.' Comment: Probably done, } \\
\text { method not described }\end{array}$ \\
\hline Allocation concealment (selection bias) & Unclear risk & $\begin{array}{l}\text { No description found in text. Comment: } \\
\text { Probably not done. }\end{array}$ \\
\hline $\begin{array}{l}\text { Blinding of outcome assessment (detection } \\
\text { bias) } \\
\text { All outcomes }\end{array}$ & Unclear risk & $\begin{array}{l}\text { No description found in text. Comment: } \\
\text { Probably not done. }\end{array}$ \\
\hline $\begin{array}{l}\text { Incomplete outcome data (attrition bias) } \\
\text { All outcomes }\end{array}$ & Unclear risk & $\begin{array}{l}\text { Attrition is described, no significant de- } \\
\text { scriptions between completers and non- } \\
\text { completers were reported }\end{array}$ \\
\hline Selective reporting (reporting bias) & Low risk & Data were fully reported. \\
\hline
\end{tabular}

Barry 1997 
Barry 1997

\begin{tabular}{|c|c|c|}
\hline Methods & \multicolumn{2}{|c|}{ RCT. Two arms. Assessed at pre-treatment, post-treatment, three months } \\
\hline Participants & \multicolumn{2}{|c|}{$\begin{array}{l}\text { End of treatment } n=29 \\
\text { Start of treatment } n=36 \\
\text { Sex: } 19 F, 10 M \\
\text { Mean age }=9.4 \\
\text { Source = Volunteers via school \& primary healthcare settings; referrals invited from } \\
\text { primary and secondary care } \\
\text { Diagnosis = Headache } \\
\text { Mean years of pain not given }\end{array}$} \\
\hline Interventions & \multicolumn{2}{|c|}{$\begin{array}{l}\text { "Cognitive behaviour therapy" } \\
\text { "Waiting list control" }\end{array}$} \\
\hline Outcomes & \multicolumn{2}{|c|}{$\begin{array}{l}\text { Primary Pain Outcome: Headache intensity } \\
\text { Primary Disability Outcome: School absence } \\
\text { Primary Mood Outcome: none } \\
\text { 1. Headache intensity } \\
\text { 2. Headache duration } \\
\text { 3. Mood } \\
\text { 4. School absence due to headache } \\
\text { 5. Activities missed due to headache } \\
\text { 6. Medication intake } \\
\text { 7. Pain management strategies used }\end{array}$} \\
\hline Notes & \multicolumn{2}{|c|}{$\begin{array}{l}\text { Original Study } \\
\text { Total Quality = 14/35 } \\
\text { Treatment Quality = 3/9 } \\
\text { Design Quality = 11/26 }\end{array}$} \\
\hline \multicolumn{3}{|l|}{ Risk of bias } \\
\hline Bias & Authors' judgement & Support for judgement \\
\hline $\begin{array}{l}\text { Random sequence generation (selection } \\
\text { bias) }\end{array}$ & Unclear risk & $\begin{array}{l}\text { 'Each parent-child pair was initially } \\
\text { matched with another pair based on the } \\
\text { child's age, sex and headache pain as in- } \\
\text { dicated by the parents' ratings of aver- } \\
\text { age duration, frequency, and intensity of } \\
\text { headaches. Subsequently, one of each of } \\
\text { them matched parent-child pairs was ran- } \\
\text { domly assigned to either the treatment con- } \\
\text { dition or the waiting list control condition. } \\
\text { 'Comment: Probably done, method not } \\
\text { described }\end{array}$ \\
\hline Allocation concealment (selection bias) & High risk & $\begin{array}{l}\text { 'Each parent-child pair was initially } \\
\text { matched with another pair based on the } \\
\text { child's age, sex and headache pain as in- } \\
\text { dicated by the parents' ratings of aver- } \\
\text { age duration, frequency, and intensity of } \\
\text { headaches. Subsequently, one of each of } \\
\text { them matched parent-child pairs was ran- } \\
\text { domly assigned to either the treatment con- } \\
\text { dition or the waiting list control condition. } \\
\text { Comment: Probably done }\end{array}$ \\
\hline
\end{tabular}


Barry 1997

\begin{tabular}{l|l|l}
\hline $\begin{array}{l}\text { Blinding of outcome assessment (detection } \\
\text { bias) } \\
\begin{array}{l}\text { All outcomes } \\
\text { Incomplete outcome data (attrition bias) }\end{array}\end{array}$ & Unclear risk & $\begin{array}{l}\text { No description found in text. Comment: } \\
\text { Probably not done. }\end{array}$ \\
\hline $\begin{array}{l}\text { All outcomes } \\
\text { Selective reporting (reporting bias) }\end{array}$ & High risk & $\begin{array}{l}\text { Attrition is described, no significant de- } \\
\text { scriptions between completers and non- } \\
\text { completers were reported }\end{array}$ \\
\hline
\end{tabular}

Bussone 1998

\begin{tabular}{|c|c|c|}
\hline Methods & \multicolumn{2}{|c|}{ RCT. Two arms. Assessed at pre-treatment, post-treatment, six months, 12 months } \\
\hline Participants & \multicolumn{2}{|c|}{$\begin{array}{l}\text { End of Treatment } n=35 \\
\text { Start of Treatment } n=35 \\
\text { Sex: } 17 \mathrm{~F}, 18 \mathrm{M} \\
\text { Mean age }=11.4 \text { (range } 11-15 \text { ) } \\
\text { Source = Specialised headache clinic } \\
\text { Diagnosis = Headache } \\
\text { Mean years of pain (mean) }=2.6\end{array}$} \\
\hline Interventions & \multicolumn{2}{|c|}{$\begin{array}{l}\text { "Biofeedback (assisted relaxation)" } \\
\text { "Relaxation" }\end{array}$} \\
\hline Outcomes & \multicolumn{2}{|c|}{$\begin{array}{l}\text { Primary Pain Outcome: Pain index } \\
\text { Primary Disability Outcome: none } \\
\text { Primary Mood Outcome: Anxiety (STAI) } \\
\text { 1. Pain Total Index (Headache Diary) } \\
\text { 2. State Trait Anxiety Index (STAI) } \\
\text { 3. Analgesic use }\end{array}$} \\
\hline Notes & \multicolumn{2}{|c|}{$\begin{array}{l}\text { Updated Study } 2009 \\
\text { Total Quality = 18/35 } \\
\text { Treatment Quality = 5/9 } \\
\text { Design Quality = 13/26 }\end{array}$} \\
\hline \multicolumn{3}{|l|}{ Risk of bias } \\
\hline Bias & Authors' judgement & Support for judgement \\
\hline $\begin{array}{l}\text { Random sequence generation (selection } \\
\text { bias) }\end{array}$ & Unclear risk & $\begin{array}{l}\text { 'Patients were randomly assigned to one of } \\
\text { two experimental conditions'. Comment: } \\
\text { Probably done, method not described }\end{array}$ \\
\hline Allocation concealment (selection bias) & High risk & $\begin{array}{l}\text { '..with the constraint that subjects be over- } \\
\text { sampled in BFB-REL treatment ( } 2: 1 \text { ratio) } \\
\text { in order to make actual treatment available } \\
\text { to as many children as possible.' Comment: } \\
\text { Probably done }\end{array}$ \\
\hline $\begin{array}{l}\text { Blinding of outcome assessment (detection } \\
\text { bias) } \\
\text { All outcomes }\end{array}$ & Unclear risk & $\begin{array}{l}\text { No description found in text. Comment: } \\
\text { Probably not done. }\end{array}$ \\
\hline
\end{tabular}




\begin{tabular}{l|l|l} 
Bussone 1998 & No dropouts reported in study. \\
$\begin{array}{l}\text { Incomplete outcome data (attrition bias) } \\
\text { All outcomes }\end{array}$ & Low risk & Data incompletely reported. \\
\hline Selective reporting (reporting bias) & High risk & \\
\hline
\end{tabular}

Connelly 2006

\begin{tabular}{|c|c|c|}
\hline Methods & \multicolumn{2}{|c|}{ RCT. Two arms. Assessed at pre-treatment, post-treatment, two months, three months } \\
\hline Participants & \multicolumn{2}{|c|}{$\begin{array}{l}\text { End of Treatment } \mathrm{n}=36 \\
\text { Start of treatment } \mathrm{n}=37 \\
\text { Sex: } 18 \mathrm{~F}, 19 \mathrm{M} \\
\text { Mean age }=10.0 \text { (range } 7-12 \text { ) } \\
\text { Source = Clinic } \\
\text { Diagnosis = Headache } \\
\text { Mean years of pain = not given }\end{array}$} \\
\hline Interventions & \multicolumn{2}{|c|}{$\begin{array}{l}\text { "CD-ROM behavioural" } \\
\text { "Wait-list neurology TAU" }\end{array}$} \\
\hline Outcomes & \multicolumn{2}{|c|}{$\begin{array}{l}\text { Primary Pain Outcome: Headache diary } \\
\text { Primary Disability Outcome: Ped-MIDAS } \\
\text { Primary Mood Outcome: none } \\
\text { 1. Total Pain (Headache diary) } \\
\text { 2. Pediatric Migraine Disability Assessment (Ped-MIDAS) }\end{array}$} \\
\hline Notes & \multicolumn{2}{|l|}{$\begin{array}{l}\text { Updated Study } 2009 \\
\text { Total Quality = 24/35 } \\
\text { Treatment Quality = 8/9 } \\
\text { Design Quality }=16 / 26\end{array}$} \\
\hline \multicolumn{3}{|l|}{ Risk of bias } \\
\hline Bias & Authors' judgement & Support for judgement \\
\hline $\begin{array}{l}\text { Random sequence generation (selection } \\
\text { bias) }\end{array}$ & Low risk & $\begin{array}{l}\text { 'Randomly assigned to one of two groups } \\
\text { by a research assistant using a uniform ran- } \\
\text { dom numbers table.' Comment: Probably } \\
\text { done }\end{array}$ \\
\hline Allocation concealment (selection bias) & Low risk & $\begin{array}{l}\text { 'Randomly assigned to one of two groups } \\
\text { by a research assistant using a uniform ran- } \\
\text { dom numbers table.' Comment: Probably } \\
\text { done }\end{array}$ \\
\hline $\begin{array}{l}\text { Blinding of outcome assessment (detection } \\
\text { bias) } \\
\text { All outcomes }\end{array}$ & Low risk & $\begin{array}{l}\text { 'Study neurologists remained blind to } \\
\text { randomisation condition throughout the } \\
\text { study. Chance of unbinding were limited } \\
\text { because follow-up appointments with the } \\
\text { study neurologist were scheduled for } 2 \\
\text { months following the initial assessment.' } \\
\text { Comment: probably done }\end{array}$ \\
\hline $\begin{array}{l}\text { Incomplete outcome data (attrition bias) } \\
\text { All outcomes }\end{array}$ & Unclear risk & $\begin{array}{l}\text { Attrition is described, however significant } \\
\text { descriptions between completers and non- } \\
\text { completers was not reported }\end{array}$ \\
\hline
\end{tabular}


Connelly 2006

\begin{tabular}{|c|c|}
\hline Selective reporting (reporting bias) & Data were fully reported. \\
\hline \multicolumn{2}{|l|}{ Duarte 2006} \\
\hline Methods & RCT. Two arms. Assessed at pre-treatment, post-treatment \\
\hline Participants & $\begin{array}{l}\text { End of Treatment } \mathrm{n}=32 \\
\text { Start of Treatment } \mathrm{n}=32 \\
\text { Sex: } 22 \mathrm{~F}, 10 \mathrm{M} \\
\text { Mean age }=9.1(\mathrm{sd} 2.1) \\
\text { Source = Paediatric gastroenterology service } \\
\text { Diagnosis = Recurrent abdominal pain } \\
\text { Mean years of pain }=2.1\end{array}$ \\
\hline Interventions & $\begin{array}{l}\text { "Cognitive behavioural family intervention" } \\
\text { "Standard paediatric care, } 4 \text { sessions" }\end{array}$ \\
\hline Outcomes & $\begin{array}{l}\text { Primary Pain Outcome: pain intensity VAS } \\
\text { Primary Disability Outcome: none } \\
\text { Primary Mood Outcome: none } \\
\text { 1. Pain VAS (reduced to } 4 \text { categories), completed daily } \\
\text { 2. Parent estimate of frequency over last month } \\
\text { 3. Pressure point threshold using algometer }\end{array}$ \\
\hline Notes & $\begin{array}{l}\text { Updated Study } 2009 \\
\text { Total Quality = 15/35 } \\
\text { Treatment Quality = 5/9 } \\
\text { Design Quality = 10/26 }\end{array}$ \\
\hline
\end{tabular}

Risk of bias

\begin{tabular}{l|l|l}
\hline Bias & Authors' judgement & Support for judgement \\
\hline $\begin{array}{l}\text { Random sequence generation (selection } \\
\text { bias) }\end{array}$ & Unclear risk & $\begin{array}{l}\text { 'Randomly allocated to 2 groups.' Com- } \\
\text { ment: Probably done, method not de- } \\
\text { scribed }\end{array}$ \\
\hline \begin{tabular}{l|ll} 
Allocation concealment (selection bias) \\
$\begin{array}{l}\text { Blinding of outcome assessment (detection } \\
\text { bias) }\end{array}$
\end{tabular} & Unclear risk & $\begin{array}{l}\text { No description found in text. Comment: } \\
\text { Probably not done. }\end{array}$ \\
\hline $\begin{array}{l}\text { Incomplete outcome data (attrition bias) } \\
\text { All outcomes }\end{array}$ & Low risk & $\begin{array}{l}\text { Po description found in text. Comment: } \\
\text { Pebly not done. }\end{array}$ \\
\hline \begin{tabular}{l} 
Selective reporting (reporting bias) \\
\hline
\end{tabular} & High risk & Data were incompletely reported. \\
\hline
\end{tabular}

Fichtel 2001

\begin{tabular}{l|l}
\hline Methods & RCT. Two arms. Assessed at pre-treatment, post-treatment, eight-12 months \\
\hline
\end{tabular}


Fichtel 2001

\begin{tabular}{|c|c|c|}
\hline Participants & \multicolumn{2}{|c|}{$\begin{array}{l}\text { End of Treatment } n=36 \\
\text { Start of Treatment } n=36 \\
\text { Sex: } 25 F, 11 M \\
\text { Mean age = } 15.4 \text { (range 13-18) } \\
\text { Source = School } \\
\text { Diagnosis = Headache } \\
\text { Mean years of pain = not given }\end{array}$} \\
\hline Interventions & \multicolumn{2}{|l|}{$\begin{array}{l}\text { "Relaxation" } \\
\text { "Waiting List Control" }\end{array}$} \\
\hline Outcomes & \multicolumn{2}{|c|}{$\begin{array}{l}\text { Primary Pain Outcome: Total headache score } \\
\text { Primary Disability Outcome: none } \\
\text { Primary Mood Outcome: none } \\
\text { 1. Total headache score (Headache diary) } \\
\text { 2. Medication consumption }\end{array}$} \\
\hline Notes & \multicolumn{2}{|l|}{$\begin{array}{l}\text { Updated Study } 2009 \\
\text { Total Quality = 15/35 } \\
\text { Treatment Quality = 4/9 } \\
\text { Design Quality = 11/26 }\end{array}$} \\
\hline \multicolumn{3}{|l|}{ Risk of bias } \\
\hline Bias & Authors' judgement & Support for judgement \\
\hline $\begin{array}{l}\text { Random sequence generation (selection } \\
\text { bias) }\end{array}$ & Unclear risk & $\begin{array}{l}\text { 'The subjects were randomly assigned to } \\
\text { the relaxation treatment or waiting list } \\
\text { groups'. Comment: Probably done, no } \\
\text { method is described }\end{array}$ \\
\hline Allocation concealment (selection bias) & Unclear risk & $\begin{array}{l}\text { No description found in text. Comment: } \\
\text { Probably not done. }\end{array}$ \\
\hline $\begin{array}{l}\text { Blinding of outcome assessment (detection } \\
\text { bias) } \\
\text { All outcomes }\end{array}$ & Unclear risk & $\begin{array}{l}\text { No description found in text. Comment: } \\
\text { Probably not done. }\end{array}$ \\
\hline $\begin{array}{l}\text { Incomplete outcome data (attrition bias) } \\
\text { All outcomes }\end{array}$ & Low risk & No dropouts were reported in the study. \\
\hline Selective reporting (reporting bias) & Low risk & Data were fully reported. \\
\hline
\end{tabular}

Gil 1997

\begin{tabular}{l|l}
\hline Methods & RCT. Two arms. Assessed at pre-treatment, post-treatment. \\
\hline Participants & End of Treatment $\mathrm{n}=49$ \\
& Start of treatment $\mathrm{n}=49$ \\
& Sex: $23 \mathrm{~F}, 26 \mathrm{M}$ \\
& Mean age $=11.9$ \\
& Source $=$ University medical centre sickle cell centre
\end{tabular}


Gil 1997

\begin{tabular}{l|l} 
& $\begin{array}{l}\text { Diagnosis = Sickle cell anaemia (SS), sickle cell disease (SC), sickle beta thalassaemia } \\
\text { Mean years of pain = not given }\end{array}$ \\
\hline Interventions & $\begin{array}{l}\text { "Cognitive coping skills" } \\
\text { "Standard care control" }\end{array}$ \\
\hline Outcomes & $\begin{array}{l}\text { Primary Pain Outcome: none } \\
\text { Primary Disability Outcome: none } \\
\text { Primary Mood Outcome: none } \\
\text { 1. Pain sensitivity (pressure stimulator) } \\
\text { 2. Coping strategy questionnaire } \\
\text { 3. Disease severity: acute and chronic complications in past 12 months }\end{array}$ \\
\hline Notes & $\begin{array}{l}\text { Original Study } \\
\text { Total Quality }=16 / 35 \\
\text { Treatment Quality }=8 / 9 \\
\text { Design Quality }=8 / 26\end{array}$ \\
&
\end{tabular}

Risk of bias

\begin{tabular}{l|l|l}
\hline Bias & Authors' judgement & Support for judgement \\
\hline $\begin{array}{l}\text { Random sequence generation (selection } \\
\text { bias) }\end{array}$ & Unclear risk & $\begin{array}{l}\text { 'Participants were then randomly assigned } \\
\text { to one of two conditions.' Comment: Prob- } \\
\text { ably done, method not described }\end{array}$ \\
\hline Allocation concealment (selection bias) & Unclear risk & $\begin{array}{l}\text { No description found in text. Comment: } \\
\text { Probably not done. }\end{array}$ \\
\hline $\begin{array}{l}\text { Blinding of outcome assessment (detection } \\
\text { bias) } \\
\text { All outcomes }\end{array}$ & Unclear risk & $\begin{array}{l}\text { No description found in text. Comment: } \\
\text { Probably not done. }\end{array}$ \\
\hline $\begin{array}{l}\text { Incomplete outcome data (attrition bias) } \\
\text { All outcomes }\end{array}$ & Low risk & No dropouts reported in study. \\
\hline Selective reporting (reporting bias) & High risk & Data not fully reported. \\
\hline
\end{tabular}

\section{Griffiths 1996}

\begin{tabular}{|c|c|}
\hline Methods & $\begin{array}{l}\text { RCT. Three arms. Assessed at pre-treatment, post-treatment and nine weeks post-treat- } \\
\text { ment }\end{array}$ \\
\hline Participants & $\begin{array}{l}\text { End of Treatment } n=42 \text {, Follow-up } n=42 \\
\text { Start of Treatment } n=51 \\
\text { Sex: } 21 \mathrm{~F}, 21 \mathrm{M} \\
\text { Mean age }=11.3 \\
\text { Source = Not known } \\
\text { Diagnosis = Migraine } \\
\text { Mean years of pain = not given: minimum } 6 \text { months }\end{array}$ \\
\hline Interventions & $\begin{array}{l}\text { "Cognitive behavioural therapy (clinic based)" } \\
\text { "cCgnitive behavioural therapy (home based)" }\end{array}$ \\
\hline
\end{tabular}




\section{Griffiths 1996}

\begin{tabular}{|c|c|c|}
\hline & \multicolumn{2}{|l|}{ "Self monitoring" } \\
\hline Outcomes & \multicolumn{2}{|c|}{$\begin{array}{l}\text { Primary Pain Outcome: headache index } \\
\text { Primary Disability Outcome: none } \\
\text { Primary Mood Outcome: Child Depression Scale } \\
\text { 1. Headache index (averaged intensity) } \\
\text { 2. Medication used } \\
\text { 3. Child Manifest Anxiety Scale (CMAS) } \\
\text { 4. Children's Depression Scale (CDS) } \\
\text { 5. Self-efficacy } \\
\text { 6. Coping responses from Children's Headache Assessment Scale (CHAS) }\end{array}$} \\
\hline Notes & \multicolumn{2}{|l|}{$\begin{array}{l}\text { Original Study } \\
\text { Total Quality = 18/35 } \\
\text { Treatment Quality = 5/9 } \\
\text { Design Quality = 13/26 }\end{array}$} \\
\hline \multicolumn{3}{|l|}{ Risk of bias } \\
\hline Bias & Authors' judgement & Support for judgement \\
\hline $\begin{array}{l}\text { Random sequence generation (selection } \\
\text { bias) }\end{array}$ & Unclear risk & $\begin{array}{l}\text { 'It was decided to assign children to groups } \\
\text { by true randomisation rather than on the } \\
\text { basis of headache diagnosis'. Comment: } \\
\text { Probably done, no method is described }\end{array}$ \\
\hline Allocation concealment (selection bias) & Unclear risk & $\begin{array}{l}\text { No description found in text. Comment: } \\
\text { Probably not done. }\end{array}$ \\
\hline $\begin{array}{l}\text { Blinding of outcome assessment (detection } \\
\text { bias) } \\
\text { All outcomes }\end{array}$ & Unclear risk & $\begin{array}{l}\text { No description found in text. Comment: } \\
\text { Probably not done. }\end{array}$ \\
\hline $\begin{array}{l}\text { Incomplete outcome data (attrition bias) } \\
\text { All outcomes }\end{array}$ & High risk & Attrition was not described. \\
\hline Selective reporting (reporting bias) & Low risk & Data were fully reported. \\
\hline
\end{tabular}

\section{Hicks 2006}

\begin{tabular}{l|l}
\hline Methods & RCT. Two arms. Assessed at pre-treatment, one month post-treatment, three months \\
\hline Participants & End of Treatment n =37, one-month follow-up = 37, three-month follow-up = 32 \\
& Start of Treatment n = 47 \\
& Sex: 30F, 17M \\
& Mean age = 11.7 (range 9-16) \\
& Source = Advertisements in media, physicians' offices and school \\
& Diagnosis = Headache and RAP \\
& Duration (mean): three years. \\
\hline Interventions & "Internet CBT (with internet and phone)" \\
& “Standard Care (Wait List)" \\
\hline
\end{tabular}


Hicks 2006

Outcomes

Primary Pain Outcome: Total Pain Score

Primary Disability Outcome: none

Primary Mood Outcome: none

1. Pain diary

2. NRS frequency

3. NRS intensity

4. PEDSQL

5. Parental Quality of Life

\begin{tabular}{l|l}
\hline Notes & Updated Study 2009 \\
& Total Quality $=27 / 35$ \\
& Treatment Quality $=8 / 9$ \\
& Design Quality $=19 / 26$ \\
\hline
\end{tabular}

Risk of bias

\begin{tabular}{|c|c|c|}
\hline Bias & Authors' judgement & Support for judgement \\
\hline $\begin{array}{l}\text { Random sequence generation (selection } \\
\text { bias) }\end{array}$ & Low risk & $\begin{array}{l}\text { 'The } 47 \text { participants were stratified by age } \\
\text { and pain severity and randomly assigned by } \\
\text { blocks to either the treatment condition or } \\
\text { the standard medical care wait-list condi- } \\
\text { tion.' Comment: Probably done }\end{array}$ \\
\hline Allocation concealment (selection bias) & Low risk & $\begin{array}{l}\text { 'The } 47 \text { participants were stratified by age } \\
\text { and pain severity and randomly assigned by } \\
\text { blocks to either the treatment condition or } \\
\text { the standard medical care wait-list condi- } \\
\text { tion.' Comment: Probably done }\end{array}$ \\
\hline $\begin{array}{l}\text { Blinding of outcome assessment (detection } \\
\text { bias) } \\
\text { All outcomes }\end{array}$ & Unclear risk & $\begin{array}{l}\text { No description found in text. Comment: } \\
\text { Probably not done. }\end{array}$ \\
\hline $\begin{array}{l}\text { Incomplete outcome data (attrition bias) } \\
\text { All outcomes }\end{array}$ & Low risk & $\begin{array}{l}\text { Attrition is described, no significant de- } \\
\text { scriptions between completers and non- } \\
\text { completers were reported }\end{array}$ \\
\hline Selective reporting (reporting bias) & High risk & Data were incompletely reported. \\
\hline
\end{tabular}

Humphreys 2000

\begin{tabular}{l|l}
\hline Methods & RCT. Four arms. Assessed at pre-treatment, post-treatment \\
\hline Participants & $\begin{array}{l}\text { End of Treatment } \mathrm{n}=61 \\
\text { Start of Treatment } \mathrm{n}=64 \\
\text { Sex: } 38 \mathrm{~F}, 26 \mathrm{M}\end{array}$ \\
& $\begin{array}{l}\text { Mean age }=9.8(\text { sd } 2.5) \\
\text { Source }=\text { Advertisement }+ \text { physician referral } \\
\text { Diagnosis = Recurrent Abdominal Pain }\end{array}$ \\
& Mean years of pain = None given \\
\hline Interventions & "CBT + biofeedback + parental support + fibre" \\
& "CBT + biofeedback + fibre"
\end{tabular}




\begin{tabular}{|c|c|c|}
\hline Humphreys 2000 & \multicolumn{2}{|l|}{$\begin{array}{l}\text { "Biofeedback + fibre" } \\
\text { "fibre" }\end{array}$} \\
\hline Outcomes & \multicolumn{2}{|c|}{$\begin{array}{l}\text { Primary Pain Outcome: Pain Diary } \\
\text { Primary Disability Outcome: School Attendance } \\
\text { Primary Mood Outcome: None } \\
\text { 1. Child Pain Diary } \\
\text { 2. Parental Observation Record } \\
\text { 3. Health Care Utilisation Record } \\
\text { 4. Medical Record } \\
\text { 5. School attendance }\end{array}$} \\
\hline Notes & \multicolumn{2}{|l|}{$\begin{array}{l}\text { Updated Study } 2009 \\
\text { Total Quality = 14/35 } \\
\text { Treatment Quality = 5/9 } \\
\text { Design Quality = 9/26 }\end{array}$} \\
\hline \multicolumn{3}{|l|}{ Risk of bias } \\
\hline Bias & Authors' judgement & Support for judgement \\
\hline $\begin{array}{l}\text { Random sequence generation (selection } \\
\text { bias) }\end{array}$ & Unclear risk & $\begin{array}{l}\text { 'Patients were randomly assigned to one } \\
\text { of the four groups'. Comment: Probably } \\
\text { done, method not described }\end{array}$ \\
\hline Allocation concealment (selection bias) & Unclear risk & $\begin{array}{l}\text { No description found in text. Comment: } \\
\text { Probably not done. }\end{array}$ \\
\hline $\begin{array}{l}\text { Blinding of outcome assessment (detection } \\
\text { bias) } \\
\text { All outcomes }\end{array}$ & Unclear risk & $\begin{array}{l}\text { No description found in text. Comment: } \\
\text { Probably not done. }\end{array}$ \\
\hline $\begin{array}{l}\text { Incomplete outcome data (attrition bias) } \\
\text { All outcomes }\end{array}$ & High risk & $\begin{array}{l}\text { Attrition not described, significant differ- } \\
\text { ences between completers and non-com- } \\
\text { pleters no reported }\end{array}$ \\
\hline Selective reporting (reporting bias) & Low risk & Data fully reported. \\
\hline
\end{tabular}

\section{Kashikar-Zuck 2005}

\begin{tabular}{l|l}
\hline Methods & RCT. Two arms. Assessed at pre-treatment, post-treatment (week 8), six weeks \\
\hline Participants & End of treatment n =27 \\
& Start of Treatment n = 30 \\
& Sex: 30F, 0M \\
& Median age = 15.8 (sd 1.3) \\
& Source = Paediatric rheumatology clinic of children's hospital \\
& Diagnosis = Juvenile primary fibromyalgia (JPFM criteria; Yunus) \\
& Mean years of pain =19 for > 2 years, 11 for 6 months to 2 years \\
\hline Interventions & "Coping skills training" \\
& "Self-monitoring" \\
\hline
\end{tabular}


Kashikar-Zuck 2005

Outcomes
Primary Pain Outcome: Average pain VAS

Primary Disability Outcome: Functional Disability Inventory

Primary Mood Outcome: Children's Depression Inventory

1. Average pain VAS 0-100

2. Highest pain VAS 0-100

3. Functional Disability Inventory (FDI)

4. Children's Depression Inventory (CDI)

5. Pain Coping Questionnaire (PCQ)

6. Pain Coping Efficacy (items from PCQ)

7. Tender points

Updated Study 2009

Total Quality $=25 / 35$

Treatment Quality $=7 / 9$

Design Quality $=18 / 26$

Risk of bias

\begin{tabular}{|c|c|c|}
\hline Bias & Authors' judgement & Support for judgement \\
\hline $\begin{array}{l}\text { Random sequence generation (selection } \\
\text { bias) }\end{array}$ & Low risk & $\begin{array}{l}\text { 'A computer generated pseudo-random } \\
\text { number list was used. A simple randomisa- } \\
\text { tion technique was used with a 1:1 alloca- } \\
\text { tion ratio for } 30 \text { subjects as a single block.' } \\
\text { Comment: Probably done }\end{array}$ \\
\hline Allocation concealment (selection bias) & Low risk & $\begin{array}{l}\text { 'A computer generated pseudo-random } \\
\text { number list was used. A simple randomisa- } \\
\text { tion technique was used with a } 1: 1 \text { alloca- } \\
\text { tion ratio for } 30 \text { subjects as a single block.' } \\
\text { Comment: Probably done }\end{array}$ \\
\hline $\begin{array}{l}\text { Blinding of outcome assessment (detection } \\
\text { bias) } \\
\text { All outcomes }\end{array}$ & Low risk & $\begin{array}{l}\text { 'A research assistant who was blind to the } \\
\text { study objectives and to the subjects' treat- } \\
\text { ment assignment administered the self-re- } \\
\text { port measures. The rheumatologist or oc- } \\
\text { cupational therapist who conducted the } \\
\text { tender point assessments was blind to } \\
\text { the subjects' treatment assignment.' Com- } \\
\text { ment: Probably done }\end{array}$ \\
\hline $\begin{array}{l}\text { Incomplete outcome data (attrition bias) } \\
\text { All outcomes }\end{array}$ & Unclear risk & $\begin{array}{l}\text { Attrition is described, however significant } \\
\text { descriptions between completers and non- } \\
\text { completers was not reported }\end{array}$ \\
\hline Selective reporting (reporting bias) & Low risk & Data were fully reported. \\
\hline
\end{tabular}

Kashikar-Zuck 2012

\begin{tabular}{l|l}
\hline Methods & RCT. Two arms. Assessed pre-treatment, post-treatment, six-month follow-up \\
\hline Participants & $\begin{array}{l}\text { End of treatment } \mathrm{n}=106, \text { Follow-up six months } \mathrm{n}=100 \\
\text { Start of treatment } \mathrm{n}=114 \\
\text { Sex: } 105 \mathrm{~F}, 9 \mathrm{M} \\
\text { Mean age }=15.0(1.8) \\
\text { Source }=\text { Paediatric rheumatology centres in Midwestern USA }\end{array}$
\end{tabular}


Kashikar-Zuck 2012

\begin{tabular}{l|l} 
& $\begin{array}{l}\text { Diagnosis = Fibromyalgia Syndrome } \\
\text { Mean years of pain = two years, 10 months (2yrs, 6mth) }\end{array}$ \\
\hline Interventions & $\begin{array}{l}\text { "Cognitive behavioural therapy" } \\
\text { "Fibromyalgia education" }\end{array}$ \\
\hline \multirow{2}{*}{ Outcomes } & $\begin{array}{l}\text { Primary Pain Outcome: Pain Severity VAS (averaged over seven days) } \\
\text { Primary Disability Outcome: Functional Disability Scale } \\
\text { Primary Mood Outcome: Children's Depression Inventory } \\
\text { 1. Pain severity VAS (averaged over seven days) } \\
\text { 2. Functional Disability Scale }\end{array}$ \\
& $\begin{array}{l}\text { 3. Children's Depression Inventory } \\
\text { 4.Tender point sensitivity }\end{array}$ \\
& $\begin{array}{l}\text { 5. Pedatric Quality of Life Inventory } \\
\text { 6. Sleep quality VAS (averaged over seven days) }\end{array}$ \\
& 7. Physician's global assessment VAS \\
\hline Notes & $\begin{array}{l}\text { Updated Study 2012 } \\
\text { Total Quality = 32/35 } \\
\text { Treatment Quality = 9/9 } \\
\text { Design Quality = 23/26 }\end{array}$ \\
\hline
\end{tabular}

Risk of bias

\begin{tabular}{l|l|l}
\hline Bias & Authors' judgement & Support for judgement \\
\hline $\begin{array}{l}\text { Random sequence generation (selection } \\
\text { bias) }\end{array}$ & Low risk & $\begin{array}{l}\text { 'Eligible patients were randomly assigned } \\
\text { to 1 of the 2 treatment arms based } \\
\text { upon a computer-generated randomisation } \\
\text { list. Randomisation was stratified by site.' } \\
\text { Comment: probably done }\end{array}$ \\
\hline Allocation concealment (selection bias) & Low risk & $\begin{array}{l}\text { 'When a patient was enrolled, the study } \\
\text { therapist contacted the biostatistician to } \\
\text { obtain the subject identification num- } \\
\text { ber and treatment allocation.' Comment: } \\
\text { Probably done }\end{array}$ \\
\hline $\begin{array}{l}\text { Blinding of outcome assessment (detection } \\
\text { bias) } \\
\text { All outcomes }\end{array}$ & Low risk & $\begin{array}{l}\text { 'The principle investigator, study physi- } \\
\text { cians, study coordinator, and assessment } \\
\text { staff were all blinded to the patients' treat- } \\
\text { ment condition throughout the trial. Pa- } \\
\text { tients were asked not to divulge what treat- } \\
\text { ment they were receiving to the study } \\
\text { physician.' Comment: Probably done }\end{array}$ \\
\hline $\begin{array}{l}\text { Incomplete outcome data (attrition bias) } \\
\text { All outcomes }\end{array}$ & Low risk & $\begin{array}{l}\text { Attrition is described, no significant de- } \\
\text { scriptions between completers and non- } \\
\text { completers were reported }\end{array}$ \\
\hline Selective reporting (reporting bias) & Low risk & \begin{tabular}{l} 
Data were fully reported. \\
\hline
\end{tabular} \\
\hline
\end{tabular}

Kroener-Herwig 2002

\begin{tabular}{l|l}
\hline Methods & RCT. Three arms. Assessed at pre-treatment, post-treatment, six months
\end{tabular}




\section{Kroener-Herwig 2002}

\begin{tabular}{|c|c|c|}
\hline Participants & $\begin{array}{l}\text { End of treatment } \mathrm{n}=7 \\
\text { Start of treatment } \mathrm{n}=7 \\
\text { Sex: } 35 \mathrm{~F}, 40 \mathrm{M} \\
\text { Mean age }=12.1 \text { (sd } 1 \text {. } \\
\text { Source = Newspaper a } \\
\text { parents } \\
\text { Diagnosis = Paediatric } \\
\text { Mean years of pain }=4\end{array}$ & $\begin{array}{l}\text { nigraine (30\%), tension-type (40\%), combined (30\%) } \\
\text { t - two or more headaches per month reported by }\end{array}$ \\
\hline Interventions & \multicolumn{2}{|c|}{$\begin{array}{l}\text { "Cognitive behavioural training group" } \\
\text { "Self-help" } \\
\text { "Waiting list control" }\end{array}$} \\
\hline Outcomes & \multicolumn{2}{|c|}{$\begin{array}{l}\text { Primary Pain Outcome: pain intensity } \\
\text { Primary Disability Outcome: none } \\
\text { Primary Mood Outcome: none } \\
\text { 1. Headache frequency (mean no. per day) } \\
\text { 2. Pain intensity (mean daily) } \\
\text { 3. Headache duration (mean no hours per day) }\end{array}$} \\
\hline Notes & \multicolumn{2}{|l|}{$\begin{array}{l}\text { Updated Study } 2012 \\
\text { Total Quality = 19/35 } \\
\text { Treatment Quality = 7/9 } \\
\text { Design Quality = 12/26 }\end{array}$} \\
\hline \multicolumn{3}{|l|}{ Risk of bias } \\
\hline Bias & Authors' judgement & Support for judgement \\
\hline $\begin{array}{l}\text { Random sequence generation (selection } \\
\text { bias) }\end{array}$ & Unclear risk & $\begin{array}{l}\text { 'Assignment to the treatment groups } \\
\text { was random.' Comment: Probably done, } \\
\text { method not described }\end{array}$ \\
\hline Allocation concealment (selection bias) & Unclear risk & $\begin{array}{l}\text { No description found in text. Comment: } \\
\text { Probably not done. }\end{array}$ \\
\hline $\begin{array}{l}\text { Blinding of outcome assessment (detection } \\
\text { bias) } \\
\text { All outcomes }\end{array}$ & Unclear risk & $\begin{array}{l}\text { No description found in text. Comment: } \\
\text { Probably not done. }\end{array}$ \\
\hline $\begin{array}{l}\text { Incomplete outcome data (attrition bias) } \\
\text { All outcomes }\end{array}$ & Unclear risk & $\begin{array}{l}\text { Attrition is described, however significant } \\
\text { descriptions between completers and non- } \\
\text { completers was not reported }\end{array}$ \\
\hline Selective reporting (reporting bias) & Low risk & Data were fully reported. \\
\hline
\end{tabular}

\section{Labbe 1984}

\begin{tabular}{l|l}
\hline Methods & $\begin{array}{l}\text { RCT. Two arms. Assessed at pre-treatment, post-treatment (one month after end of } \\
\text { treatment), six months }\end{array}$ \\
\hline Participants & $\begin{array}{l}\text { End of treatment } n=28 \\
\text { Start of Treatment } n=28\end{array}$
\end{tabular}


Labbe 1984

\begin{tabular}{|c|c|c|}
\hline & \multicolumn{2}{|c|}{$\begin{array}{l}\text { Sex: } 14 \mathrm{~F}, 14 \mathrm{M} \\
\text { Mean age }=10.8 \\
\text { Source }=\text { Community paediatrician referral, newspaper advertisement } \\
\text { Diagnosis = Migraine headache } \\
\text { Mean years of pain }=4.3\end{array}$} \\
\hline Interventions & \multicolumn{2}{|c|}{$\begin{array}{l}\text { "Autogenic feedback training" } \\
\text { "Waiting list control" }\end{array}$} \\
\hline Outcomes & \multicolumn{2}{|c|}{$\begin{array}{l}\text { Primary Pain Outcome: Headache diary } \\
\text { Primary Disability Outcome: none } \\
\text { Primary Mood Outcome: none } \\
\text { 1. Headache index } \\
\text { 2. Headache frequency } \\
\text { 3. Headache duration } \\
\text { 4. Headache peak intensity } \\
\text { 5. Medication use }\end{array}$} \\
\hline Notes & \multicolumn{2}{|l|}{$\begin{array}{l}\text { Original Study } \\
\text { Total Quality = 16/35 } \\
\text { Treatment Quality }=4 / 9 \\
\text { Design Quality }=12 / 26\end{array}$} \\
\hline \multicolumn{3}{|l|}{ Risk of bias } \\
\hline Bias & Authors' judgement & Support for judgement \\
\hline $\begin{array}{l}\text { Random sequence generation (selection } \\
\text { bias) }\end{array}$ & Unclear risk & $\begin{array}{l}\text { 'The children who attended the first ses- } \\
\text { sion were matched on age, sex, and base- } \\
\text { line headache index and then randomly as- } \\
\text { signed to either a treatment group or wait- } \\
\text { ing-list control group.' Comment: Proba- } \\
\text { bly done, method not described }\end{array}$ \\
\hline Allocation concealment (selection bias) & Unclear risk & $\begin{array}{l}\text { No description found in text. Comment: } \\
\text { Probably not done. }\end{array}$ \\
\hline $\begin{array}{l}\text { Blinding of outcome assessment (detection } \\
\text { bias) } \\
\text { All outcomes }\end{array}$ & Unclear risk & $\begin{array}{l}\text { No description found in text. Comment: } \\
\text { Probably not done. }\end{array}$ \\
\hline $\begin{array}{l}\text { Incomplete outcome data (attrition bias) } \\
\text { All outcomes }\end{array}$ & Low risk & No dropouts reported in study. \\
\hline Selective reporting (reporting bias) & Low risk & Data were reported fully. \\
\hline
\end{tabular}

\section{Labbe 1995}

\begin{tabular}{l|l}
\hline Methods & RCT. Three arms. Assessed at pre-treatment, post-treatment, six months \\
\hline Participants & $\begin{array}{l}\text { End of treatment } n=30 \\
\text { Start of Treatment } n=46 \\
\text { Sex: } 17 \mathrm{~F}, 13 \mathrm{M}\end{array}$
\end{tabular}


Labbe 1995

\begin{tabular}{|c|c|}
\hline & $\begin{array}{l}\text { Mean age }=12.0 \\
\text { Source }=\text { Not given } \\
\text { Diagnosis = Vascular or migraine headache } \\
\text { Mean years of pain = not given. }\end{array}$ \\
\hline Interventions & $\begin{array}{l}\text { "Skin temperature biofeedback and autogenic relaxation" } \\
\text { "Autogenic relaxation" } \\
\text { "Waiting list control" }\end{array}$ \\
\hline Outcomes & $\begin{array}{l}\text { Primary Pain Outcome: headache diary } \\
\text { Primary Disability Outcome: none } \\
\text { Primary Mood Outcome: Childhood Depression Inventory } \\
\text { 1. Headache index } \\
\text { 2. Headache frequency } \\
\text { 3. Headache duration } \\
\text { 4. Child aggression parent-rated (Myth Type A) } \\
\text { 5. Childhood Depression Inventory } \\
\text { 6. How-I-Feel questionnaire: anxiety }\end{array}$ \\
\hline Notes & $\begin{array}{l}\text { Original Study } \\
\text { Total Quality = 11/35 } \\
\text { Treatment Quality }=2 / 9 \\
\text { Design Quality = 9/26 }\end{array}$ \\
\hline
\end{tabular}

Risk of bias

\begin{tabular}{l|l|l}
\hline Bias & Authors' judgement & Support for judgement \\
\hline $\begin{array}{l}\text { Random sequence generation (selection } \\
\text { bias) }\end{array}$ & Unclear risk & $\begin{array}{l}\text { 'Children were matched by age, sex, and } \\
\text { baseline headache activity and then ran- } \\
\text { domly assigned to one of three groups.' } \\
\text { Comment: Probably done, no method de- } \\
\text { scribed }\end{array}$ \\
\hline Allocation concealment (selection bias) & Unclear risk & $\begin{array}{l}\text { No description found in text. Comment: } \\
\text { Probably not done. }\end{array}$ \\
\hline $\begin{array}{l}\text { Blinding of outcome assessment (detection } \\
\text { bias) } \\
\text { All outcomes }\end{array}$ & Unclear risk & $\begin{array}{l}\text { No description found in text. Comment: } \\
\text { Probably not done. }\end{array}$ \\
\hline $\begin{array}{l}\text { Incomplete outcome data (attrition bias) } \\
\text { All outcomes }\end{array}$ & Low risk & $\begin{array}{l}\text { 'Data on the dropouts were compared to } \\
\text { those children participating in the treat- } \\
\text { ment sessions. No differences were found } \\
\text { in sex, age or headache history.' Comment: } \\
\text { Probably done }\end{array}$ \\
\hline Selective reporting (reporting bias) & Low risk & \begin{tabular}{l} 
Data were fully reported. \\
\hline
\end{tabular} \\
\hline
\end{tabular}

Larsson 1987a

\begin{tabular}{l|l}
\hline Methods & RCT. Three arms. Assessed at pre-treatment, post-treatment, five months \\
\hline Participants & End of treatment $\mathrm{n}=46$
\end{tabular}


Larsson 1987a

\begin{tabular}{|c|c|}
\hline & $\begin{array}{l}\text { Start of Treatment } n=46 \\
\text { Sex: } 40 F, 6 M \\
\text { Mean age = Not given: range } 16-18 \\
\text { Source = Not given } \\
\text { Diagnosis = Headache (migraine, tension, or both) } \\
\text { Mean years of pain = Most one-five years }\end{array}$ \\
\hline Interventions & $\begin{array}{l}\text { "Therapist assisted relaxation" } \\
\text { "Self-help relaxation" } \\
\text { "Self monitoring group" }\end{array}$ \\
\hline Outcomes & $\begin{array}{l}\text { Primary Pain Outcome: Headache sum } \\
\text { Primary Disability Outcome: school absence } \\
\text { Primary Mood Outcome: none } \\
\text { 1. Headache sum } \\
\text { 2. Headache frequency } \\
\text { 3. Headache-free days } \\
\text { 4. Headache duration } \\
\text { 5. Peak headache intensity } \\
\text { 6. Medication } \\
\text { 7. School absence } \\
\text { 8. Significant other rating of headache improvement } \\
\text { 9. Cost-effectiveness }\end{array}$ \\
\hline Notes & $\begin{array}{l}\text { Original Study } \\
\text { Total Quality = 21/35 } \\
\text { Treatment Quality = 6/9 } \\
\text { Design Quality = 15/26 }\end{array}$ \\
\hline
\end{tabular}

Risk of bias

\begin{tabular}{|c|c|c|}
\hline Bias & Authors' judgement & Support for judgement \\
\hline $\begin{array}{l}\text { Random sequence generation (selection } \\
\text { bias) }\end{array}$ & Unclear risk & $\begin{array}{l}\text { 'In the randomisation procedure'. Com- } \\
\text { ment: Probably done, no method described }\end{array}$ \\
\hline Allocation concealment (selection bias) & High risk & $\begin{array}{l}\text { 'In the randomisation procedure the fol- } \\
\text { lowing restrictions were applied: (a) class } \\
\text { mates were assigned to the same treat- } \\
\text { ment group in order to lessen the risk of } \\
\text { treatment contamination, (b) subjects were } \\
\text { evenly distributed across groups within sep- } \\
\text { arate schools.' Comment: Probably done }\end{array}$ \\
\hline $\begin{array}{l}\text { Blinding of outcome assessment (detection } \\
\text { bias) } \\
\text { All outcomes }\end{array}$ & Unclear risk & $\begin{array}{l}\text { No description found in text. Comment: } \\
\text { Probably not done. }\end{array}$ \\
\hline $\begin{array}{l}\text { Incomplete outcome data (attrition bias) } \\
\text { All outcomes }\end{array}$ & Unclear risk & $\begin{array}{l}\text { Attrition is described, however significant } \\
\text { differences between completers and non- } \\
\text { completers were not reported }\end{array}$ \\
\hline Selective reporting (reporting bias) & High risk & Data were not fully reported. \\
\hline
\end{tabular}


Larsson 1987b

\begin{tabular}{|c|c|c|}
\hline Methods & \multicolumn{2}{|c|}{ RCT. Three arms. Assessed at pre-treatment, post-treatment, five months } \\
\hline Participants & \multicolumn{2}{|c|}{$\begin{array}{l}\text { End of treatment } n=36 \text {, follow-up } n=34 \\
\text { Start of Treatment } n=36 \\
\text { Sex: } 32 F, 2 M \\
\text { Mean age }=17 \\
\text { Source = Not given } \\
\text { Diagnosis = Headache } \\
\text { Mean years of pain = Most } 1-5 \text { years }\end{array}$} \\
\hline Interventions & \multicolumn{2}{|c|}{$\begin{array}{l}\text { "Self-help relaxation" } \\
\text { "Problem discussion group" } \\
\text { "Self monitoring (control)" }\end{array}$} \\
\hline Outcomes & \multicolumn{2}{|c|}{$\begin{array}{l}\text { Primary Pain Outcome: Headache sum } \\
\text { Primary Disability Outcome: School absence } \\
\text { Primary Mood Outcome: Depression } \\
\text { 1. Headache sum } \\
\text { 2. Headache frequency } \\
\text { 3. Headache-free days } \\
\text { 4. Headache duration } \\
\text { 5. Peak headache intensity } \\
\text { 6. Medicine consumption } \\
\text { 7. School absence } \\
\text { 8. Headache annoyance } \\
\text { 9. Depression/anxiety } \\
\text { 10. Social relationship-competence questionnaire } \\
\text { 11. Significant other rating of headache improvement }\end{array}$} \\
\hline Notes & \multicolumn{2}{|l|}{$\begin{array}{l}\text { Original Study } \\
\text { Total Quality = 16/35 } \\
\text { Treatment Quality = 5/9 } \\
\text { Design Quality = 11/26 }\end{array}$} \\
\hline \multicolumn{3}{|l|}{ Risk of bias } \\
\hline Bias & Authors' judgement & Support for judgement \\
\hline $\begin{array}{l}\text { Random sequence generation (selection } \\
\text { bias) }\end{array}$ & Unclear risk & $\begin{array}{l}\text { 'Finally, } 36 \text { students were randomly as- } \\
\text { signed to the three experimental con- } \\
\text { ditions.' Comment: Probably done, no } \\
\text { method described }\end{array}$ \\
\hline Allocation concealment (selection bias) & High risk & $\begin{array}{l}\text { 'The allocation of subjects was conducted } \\
\text { with two restrictions on the procedure: (a) } \\
\text { Classmates were assigned to the same treat- } \\
\text { ment condition (to lessen the risk of treat- } \\
\text { ment contamination), and (b) students } \\
\text { with a high frequency of headaches were } \\
\text { identified and evenly distributed across } \\
\text { groups.' Comment: Probably done }\end{array}$ \\
\hline
\end{tabular}




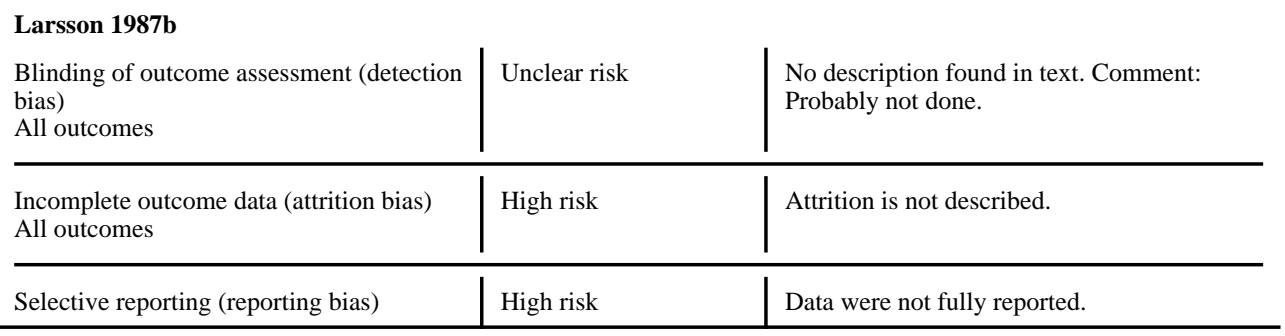

Larsson 1990

\begin{tabular}{|c|c|c|}
\hline Methods & \multicolumn{2}{|c|}{ RCT Two arms. Assessed at pre-treatment, post-treatment } \\
\hline Participants & \multicolumn{2}{|c|}{$\begin{array}{l}\text { End of treatment } n=43 \\
\text { Start of Treatment } n=49 \\
\text { Sex: } 44 \mathrm{~F}, 5 \mathrm{M} \\
\text { Mean age }=17 \\
\text { Source }=\text { School } \\
\text { Diagnosis }=\text { Headache } \\
\text { Mean years of pain }=\text { median } 2-5 \text { years }\end{array}$} \\
\hline Interventions & \multicolumn{2}{|l|}{$\begin{array}{l}\text { "Self help relaxation" } \\
\text { "Waiting list control" }\end{array}$} \\
\hline Outcomes & \multicolumn{2}{|c|}{$\begin{array}{l}\text { Primary Pain Outcome: Headache activity } \\
\text { Primary Disability Outcome: none given } \\
\text { Primary Mood Outcome: Depression (BDI) } \\
\text { 1. Headache index } \\
\text { 2. Medication use } \\
\text { 3. Headache annoyance } \\
\text { 4. Modified Child Manifest Anxiety Scale (CMAS) } \\
\text { 5. Depression - Beck Depression Inventory } \\
\text { 6. Somatic complaints (composite of multiple complaints) } \\
\text { 7. Stress (4-point scale) }\end{array}$} \\
\hline Notes & \multicolumn{2}{|l|}{$\begin{array}{l}\text { Original Study } \\
\text { Total Quality = 12/35 } \\
\text { Treatment Quality = 4/9 } \\
\text { Design Quality = 8/26 }\end{array}$} \\
\hline \multicolumn{3}{|l|}{ Risk of bias } \\
\hline Bias & Authors' judgement & Support for judgement \\
\hline $\begin{array}{l}\text { Random sequence generation (selection } \\
\text { bias) }\end{array}$ & Unclear risk & $\begin{array}{l}\text { '...the outlines of the study including the } \\
\text { use of randomisation and a placebo treat- } \\
\text { ment period.' Comment: Probably done, } \\
\text { method not described }\end{array}$ \\
\hline Allocation concealment (selection bias) & Unclear risk & $\begin{array}{l}\text { No description found in text. Comment: } \\
\text { Probably not done. }\end{array}$ \\
\hline
\end{tabular}




\begin{tabular}{|c|c|c|}
\hline Larsson 1990 & & \\
\hline $\begin{array}{l}\text { bias) } \\
\text { All outcomes }\end{array}$ & & $\begin{array}{l}\text { istered the assessment instruments and the } \\
\text { treatment material used in the study.' Com- } \\
\text { ment: unsure }\end{array}$ \\
\hline $\begin{array}{l}\text { Incomplete outcome data (attrition bias) } \\
\text { All outcomes }\end{array}$ & Unclear risk & $\begin{array}{l}\text { Attrition is described, however significant } \\
\text { descriptions between completers and non- } \\
\text { completers was not reported }\end{array}$ \\
\hline Selective reporting (reporting bias) & Low risk & Data were fully reported. \\
\hline
\end{tabular}

Larsson 1996

\begin{tabular}{|c|c|c|}
\hline Methods & \multicolumn{2}{|c|}{ RCT. Two arms. Assessed at pre-treatment, post-treatment, six months } \\
\hline Participants & \multicolumn{2}{|c|}{$\begin{array}{l}\text { End of treatment } \mathrm{n}=26 \\
\text { Start of Treatment } \mathrm{n}=26 \\
\text { Sex: } 25 \mathrm{~F}, 1 \mathrm{M} \\
\text { Mean age = Not given: range } 10-15 \text { years } \\
\text { Source = School } \\
\text { Diagnosis }=\text { Headache } \\
\text { Mean years of pain }=2.1\end{array}$} \\
\hline Interventions & \multicolumn{2}{|l|}{$\begin{array}{l}\text { "Relaxation treatment" } \\
\text { "No treatment" }\end{array}$} \\
\hline Outcomes & \multicolumn{2}{|c|}{$\begin{array}{l}\text { Primary Pain Outcome: Headache intensity } \\
\text { Primary Disability Outcome: None } \\
\text { Primary Mood Outcome: None } \\
\text { 1. Headache intensity ('sum') } \\
\text { 2. Headache-free days } \\
\text { 3. Headache frequency }\end{array}$} \\
\hline Notes & \multicolumn{2}{|l|}{$\begin{array}{l}\text { Original Study } \\
\text { Total Quality = 20/35 } \\
\text { Treatment Quality = 6/9 } \\
\text { Design Quality = 14/26 }\end{array}$} \\
\hline \multicolumn{3}{|l|}{ Risk of bias } \\
\hline Bias & Authors' judgement & Support for judgement \\
\hline $\begin{array}{l}\text { Random sequence generation (selection } \\
\text { bias) }\end{array}$ & Unclear risk & $\begin{array}{l}\text { 'Thus, } 26 \text { pupils were randomly allocated } \\
\text { into a relaxation training group or to a no- } \\
\text { treatment control group'. Comment: Prob- } \\
\text { ably done, no method described }\end{array}$ \\
\hline Allocation concealment (selection bias) & Unclear risk & $\begin{array}{l}\text { No description found in text. Comment: } \\
\text { Probably not done. }\end{array}$ \\
\hline $\begin{array}{l}\text { Blinding of outcome assessment (detection } \\
\text { bias) } \\
\text { All outcomes }\end{array}$ & Unclear risk & $\begin{array}{l}\text { No description found in text. Comment: } \\
\text { Probably not done. }\end{array}$ \\
\hline $\begin{array}{l}\text { Incomplete outcome data (attrition bias) } \\
\text { All outcomes }\end{array}$ & Low risk & $\begin{array}{l}\text { There were no dropouts reported in the } \\
\text { study. }\end{array}$ \\
\hline
\end{tabular}


Larsson 1996

\begin{tabular}{l|l|l}
\hline Selective reporting (reporting bias) & Low risk & Data were fully reported. \\
\hline
\end{tabular}

Levy 2010

\begin{tabular}{|c|c|}
\hline Methods & $\begin{array}{l}\text { RCT. Two arms. Assessed at pre-treatment, post-treatment, three-month follow-up, six- } \\
\text { month follow-up }\end{array}$ \\
\hline Participants & $\begin{array}{l}\text { End of treatment } \mathrm{n}=168 \text {, Follow-up three months } \mathrm{n}=143 \text {, Follow-up six months }= \\
154 \\
\text { Start of treatment } \mathrm{n}=200 \\
\text { Sex: } 145 \mathrm{~F}, 55 \mathrm{M} \\
\text { Mean age = } 11.21(2.55) \\
\text { Source = Pediatric gastroenterology clinics at Seattle Children's Hospital and the At- } \\
\text { lantic Health System in Morristown, New Jersey. Seattle participants were also recruited } \\
\text { through local area clinics and community-posted flyers } \\
\text { Diagnosis = Functional Abdominal Pain } \\
\text { Mean years of pain =3+ episodes of abdominal pain during a 3-month period }\end{array}$ \\
\hline Interventions & $\begin{array}{l}\text { "Cognitive-behavioural treatment" } \\
\text { "Educational intervention" }\end{array}$ \\
\hline Outcomes & $\begin{array}{l}\text { Primary Pain Outcome: Faces Pain Scale-Revised } \\
\text { Primary Disability Outcome: Functional Disability Inventory } \\
\text { Primary Mood Outcome: Children's Depression Inventory } \\
\text { 1. Faces Pain Scale-Revised } \\
\text { 2. Functional Disability Inventory } \\
\text { 3. Children's Depression Inventory } \\
\text { 4. Children's Somatization Inventory } \\
\text { 5. Multidimensional Anxiety Scale for Children }\end{array}$ \\
\hline Notes & $\begin{array}{l}\text { Updated study } 2012 \\
\text { Total Quality }=27 / 35 \\
\text { Treatment Quality = 7/9 } \\
\text { Design Quality }=20 / 26\end{array}$ \\
\hline
\end{tabular}

Risk of bias

\begin{tabular}{|c|c|c|}
\hline Bias & Authors' judgement & Support for judgement \\
\hline $\begin{array}{l}\text { Random sequence generation (selection } \\
\text { bias) }\end{array}$ & Low risk & $\begin{array}{l}\text { 'Randomisation was then performed by a } \\
\text { different researcher using a computerised } \\
\text { random-number generator, stratifying by } \\
\text { age.' Comment: probably done }\end{array}$ \\
\hline Allocation concealment (selection bias) & Low risk & $\begin{array}{l}\text { 'Randomisation was then performed by a } \\
\text { different researcher using a computerised } \\
\text { random-number generator, stratifying by } \\
\text { age.' Comment: probably done }\end{array}$ \\
\hline $\begin{array}{l}\text { Blinding of outcome assessment (detection } \\
\text { bias) } \\
\text { All outcomes }\end{array}$ & Low risk & $\begin{array}{l}\text { 'Nurse assessors were blind to the treat- } \\
\text { ment assignment of the children.' Com- } \\
\text { ment: Probably done }\end{array}$ \\
\hline Incomplete outcome data (attrition bias) & Unclear risk & Attrition is described, significant differ- \\
\hline
\end{tabular}


Levy 2010

\begin{tabular}{l|l|l} 
All outcomes & & $\begin{array}{l}\text { ences between completers and non-com- } \\
\text { pleters are not reported }\end{array}$ \\
\hline Selective reporting (reporting bias) & Low risk & Data were fully reported. \\
\hline
\end{tabular}

\section{McGrath 1988}

\begin{tabular}{|c|c|c|}
\hline Methods & \multicolumn{2}{|c|}{ RCT. Three arms. Assessed at pre-treatment, post-treatment, three months, 12 months } \\
\hline Participants & \multicolumn{2}{|c|}{$\begin{array}{l}\text { End of treatment } n=99 \\
\text { Start of Treatment } n=136 \\
\text { Sex: } 69 F, 30 M \\
\text { Mean age =13.1 (range 11-18) } \\
\text { source = Hospital } \\
\text { Diagnosis = Headache } \\
\text { Mean years of pain = not given: minimum three months }\end{array}$} \\
\hline Interventions & \multicolumn{2}{|l|}{$\begin{array}{l}\text { "Relaxation training" } \\
\text { "Attention control" } \\
\text { "Own best efforts" }\end{array}$} \\
\hline Outcomes & \multicolumn{2}{|c|}{$\begin{array}{l}\text { Primary Pain Outcome: Headache index } \\
\text { Primary Disability Outcome: none } \\
\text { Primary Mood Outcome: none } \\
\text { 1. Headache index } \\
\text { 2. Headache-free days } \\
\text { 3. Highest pain intensity }\end{array}$} \\
\hline Notes & \multicolumn{2}{|l|}{$\begin{array}{l}\text { Original Study } \\
\text { Total Quality = 23/35 } \\
\text { Treatment Quality = 7/9 } \\
\text { Design Quality = 16/26 }\end{array}$} \\
\hline \multicolumn{3}{|l|}{ Risk of bias } \\
\hline Bias & Authors' judgement & Support for judgement \\
\hline $\begin{array}{l}\text { Random sequence generation (selection } \\
\text { bias) }\end{array}$ & Unclear risk & $\begin{array}{l}\text { 'Randomly assigned to one of three groups'. } \\
\text { Comment: Probably done, no method de- } \\
\text { scribed }\end{array}$ \\
\hline Allocation concealment (selection bias) & Unclear risk & $\begin{array}{l}\text { No description found in text. Comment: } \\
\text { Probably not done. }\end{array}$ \\
\hline $\begin{array}{l}\text { Blinding of outcome assessment (detection } \\
\text { bias) } \\
\text { All outcomes }\end{array}$ & Unclear risk & $\begin{array}{l}\text { No description found in text. Comment: } \\
\text { Probably not done. }\end{array}$ \\
\hline $\begin{array}{l}\text { Incomplete outcome data (attrition bias) } \\
\text { All outcomes }\end{array}$ & Low risk & $\begin{array}{l}\text { Attrition is described, however significant } \\
\text { differences between completers and non- } \\
\text { completers are not reported }\end{array}$ \\
\hline Selective reporting (reporting bias) & Low risk & Data were completely reported. \\
\hline
\end{tabular}


McGrath 1992

\begin{tabular}{|c|c|c|}
\hline Methods & \multicolumn{2}{|c|}{$\begin{array}{l}\text { RCT. Three arms. Assessed at pre-treatment, post-treatment, three months and one-year } \\
\text { follow-up }\end{array}$} \\
\hline Participants & \multicolumn{2}{|c|}{$\begin{array}{l}\text { End of treatment } n=74 \\
\text { Start of Treatment } n=87 \\
\text { Sex: } 63 F, 24 M \\
\text { Mean age = Not given: range } 11-18 \text { years } \\
\text { Source = Paediatricians and family physicians } \\
\text { Diagnosis = Migraine } \\
\text { Mean years of pain not given: minimum three months }\end{array}$} \\
\hline Interventions & \multicolumn{2}{|c|}{$\begin{array}{l}\text { "Therapist administered cognitive behavioural/stress coping/ relaxation training" } \\
\text { "Self-administered cognitive behavioural/ stress coping/ relaxation training" } \\
\text { "Information and support" }\end{array}$} \\
\hline Outcomes & \multicolumn{2}{|c|}{$\begin{array}{l}\text { Primary Pain Outcome: Headache diary } \\
\text { Primary Disability Outcome: None } \\
\text { Primary Mood Outcome: Depression } \\
\text { 1. Headache index } \\
\text { 2. Efficiency of treatment } \\
\text { 3. Poznanski Depression Scale }\end{array}$} \\
\hline Notes & \multicolumn{2}{|l|}{$\begin{array}{l}\text { Original Study } \\
\text { Total Quality = 15/35 } \\
\text { Treatment Quality = 2/9 } \\
\text { Design Quality = 13/26 }\end{array}$} \\
\hline \multicolumn{3}{|l|}{ Risk of bias } \\
\hline Bias & Authors' judgement & Support for judgement \\
\hline $\begin{array}{l}\text { Random sequence generation (selection } \\
\text { bias) }\end{array}$ & Unclear risk & $\begin{array}{l}\text { 'Randomised to } 1 \text { of the } 8 \text {-week treat- } \\
\text { ments'. Comment: Probably done, no } \\
\text { method described }\end{array}$ \\
\hline Allocation concealment (selection bias) & Unclear risk & $\begin{array}{l}\text { No description found in text. Comment: } \\
\text { Probably not done. }\end{array}$ \\
\hline $\begin{array}{l}\text { Blinding of outcome assessment (detection } \\
\text { bias) } \\
\text { All outcomes }\end{array}$ & Unclear risk & $\begin{array}{l}\text { No description found in text. Comment: } \\
\text { Probably not done. }\end{array}$ \\
\hline $\begin{array}{l}\text { Incomplete outcome data (attrition bias) } \\
\text { All outcomes }\end{array}$ & Unclear risk & $\begin{array}{l}\text { Attrition is described, however significant } \\
\text { differences between completers and non- } \\
\text { completers are not reported }\end{array}$ \\
\hline Selective reporting (reporting bias) & High risk & Data were incompletely reported. \\
\hline
\end{tabular}

\section{Osterhaus 1997}

\begin{tabular}{l|l}
\hline Methods & RCT. Two arms. Assessed at pre-treatment, post-treatment and one-year follow-up \\
\hline Participants & End of treatment $n=39$, one-year follow-up $n=21$.
\end{tabular}


Osterhaus 1997

\begin{tabular}{|c|c|c|}
\hline & \multicolumn{2}{|c|}{$\begin{array}{l}\text { Start of Treatment } n=39 \\
\text { Sex: } 29 \mathrm{~F}, 10 \mathrm{M} \\
\text { Mean age }=15.2(\mathrm{sd} 3.3) \\
\text { Source = Newspaper article } \\
\text { Diagnosis = Headache (migraine, tension-type, mixed) } \\
\text { Mean years of pain = 5.6 }\end{array}$} \\
\hline Interventions & \multicolumn{2}{|c|}{$\begin{array}{l}\text { "Behavioural treatment package" } \\
\text { "Waiting list control" }\end{array}$} \\
\hline Outcomes & \multicolumn{2}{|c|}{$\begin{array}{l}\text { Primary Pain Outcome: Headache index } \\
\text { Primary Disability Outcome: none } \\
\text { Primary Mood Outcome: none } \\
\text { 1. Headache index } \\
\text { 2. Headache frequency } \\
\text { 3. Headache duration } \\
\text { 4. Headache intensity }\end{array}$} \\
\hline Notes & \multicolumn{2}{|c|}{$\begin{array}{l}\text { Original Study } \\
\text { Total Quality = 18/35 } \\
\text { Treatment Quality = 6/9 } \\
\text { Design Quality = 12/26 }\end{array}$} \\
\hline \multicolumn{3}{|l|}{ Risk of bias } \\
\hline Bias & Authors' judgement & Support for judgement \\
\hline $\begin{array}{l}\text { Random sequence generation (selection } \\
\text { bias) }\end{array}$ & Unclear risk & $\begin{array}{l}\text { 'The participants were randomly assigned } \\
\text { to one of two groups'. Comment: Probably } \\
\text { done, no method described }\end{array}$ \\
\hline Allocation concealment (selection bias) & Unclear risk & $\begin{array}{l}\text { No description found in text. Comment: } \\
\text { Probably not done. }\end{array}$ \\
\hline $\begin{array}{l}\text { Blinding of outcome assessment (detection } \\
\text { bias) } \\
\text { All outcomes }\end{array}$ & Unclear risk & $\begin{array}{l}\text { No description found in text. Comment: } \\
\text { Probably not done. }\end{array}$ \\
\hline $\begin{array}{l}\text { Incomplete outcome data (attrition bias) } \\
\text { All outcomes }\end{array}$ & High risk & Attrition is not described. \\
\hline Selective reporting (reporting bias) & Low risk & Data were fully reported. \\
\hline
\end{tabular}

Palermo 2009

\begin{tabular}{l|l}
\hline Methods & RCT. Two arms. Assessed at pre-treatment and post-treatment. \\
\hline Participants & End of treatment $\mathrm{n}=44$ \\
& Start of treatment $\mathrm{n}=48$ \\
& Sex: $35 \mathrm{~F}, 13 \mathrm{M}$ \\
& Mean age $=14.8(2.0)$ \\
& Source $=$ Medical centre in the Pacific Northwest USA
\end{tabular}


Palermo 2009

\begin{tabular}{|c|c|}
\hline & $\begin{array}{l}\text { Diagnosis }=\text { Headache ( } 25 \% \text { of the sample), abdominal pain }(50 \% \text { of the sample), or } \\
\text { musculoskeletal pain ( } 25 \% \text { of the sample) } \\
\text { Mean years of pain }=30 \text { months }\end{array}$ \\
\hline Interventions & $\begin{array}{l}\text { "Internet-delivered family cognitive-behavioural therapy" } \\
\text { "Wait-list control group" }\end{array}$ \\
\hline Outcomes & $\begin{array}{l}\text { Primary Pain Outcome: Daily Pain Intensity NRS (averaged over seven days) } \\
\text { Primary Disability Outcome: Child Acitivty and Limitations Interview } \\
\text { Primary Mood Outcome: Revised Child Anxiety and Depression Scale } \\
\text { 1. Daily pain intensity NRS (averaged over seven days) } \\
\text { 2. Usual pain intensity over the past month NRS } \\
\text { 2. Child Activity Limitations Interview } \\
\text { 3. Revised Child Anxiety and Depression Scale } \\
\text { 4. Protect sub scale from Adult Responses to Children's Symtpoms } \\
\text { 5. Treatment acceptability and satisfaction }\end{array}$ \\
\hline Notes & $\begin{array}{l}\text { Updated Study } 2012 \\
\text { Total Quality = 30/35 } \\
\text { Treatment Quality = 8/9 } \\
\text { Design Quality = 22/26 }\end{array}$ \\
\hline
\end{tabular}

Risk of bias

\begin{tabular}{|c|c|c|}
\hline Bias & Authors' judgement & Support for judgement \\
\hline $\begin{array}{l}\text { Random sequence generation (selection } \\
\text { bias) }\end{array}$ & Low risk & $\begin{array}{l}\text { 'A fixed allocation randomisation scheme } \\
\text { was used. Specifically, we used blocked ran- } \\
\text { domisation with blocks of } 10 \text { to assign } \\
\text { participants to the two treatment condi- } \\
\text { tions during the course of randomisation. } \\
\text { An online random number generator was } \\
\text { used to produce the blocked randomisa- } \\
\text { tion. Group assignments were identified by } \\
\text { ID number in sealed envelopes. Follow- } \\
\text { ing completion of all pre-treatment assess- } \\
\text { ments, a research coordinator opened the } \\
\text { sealed envelope to reveal the group assign- } \\
\text { ment.' Comment: probably done }\end{array}$ \\
\hline Allocation concealment (selection bias) & Low risk & $\begin{array}{l}\text { 'A fixed allocation randomisation scheme } \\
\text { was used. Specifically, we used blocked ran- } \\
\text { domisation with blocks of } 10 \text { to assign } \\
\text { participants to the two treatment condi- } \\
\text { tions during the course of randomisation. } \\
\text { An online random number generator was } \\
\text { used to produce the blocked randomisa- } \\
\text { tion. Group assignments were identified by } \\
\text { ID number in sealed envelopes. Follow- } \\
\text { ing completion of all pre-treatment assess- } \\
\text { ments, a research coordinator opened the } \\
\text { sealed envelope to reveal the group assign- } \\
\text { ment.' Comment: probably done }\end{array}$ \\
\hline $\begin{array}{l}\text { Blinding of outcome assessment (detection } \\
\text { bias) } \\
\text { All outcomes }\end{array}$ & Unclear risk & $\begin{array}{l}\text { No description found in text. Comment: } \\
\text { Probably not done. }\end{array}$ \\
\hline Incomplete outcome data (attrition bias) & Unclear risk & $\begin{array}{l}\text { Attrition is described, however significant } \\
\text { differences between completers and non- }\end{array}$ \\
\hline
\end{tabular}


Palermo 2009

\begin{tabular}{l|l|l} 
All outcomes & & completers were not described \\
\hline Selective reporting (reporting bias) & Low risk & Data were fully reported. \\
\hline
\end{tabular}

Passchier 1990

\begin{tabular}{|c|c|c|}
\hline Methods & \multicolumn{2}{|c|}{ RCT. Two arms. Assessed at pre-treatment, post-treatment. } \\
\hline Participants & \multicolumn{2}{|c|}{$\begin{array}{l}\text { End of treatment } \mathrm{n}=119 \\
\text { Start of Treatment } \mathrm{n}=119 \\
\text { Sex: } 65 \mathrm{~F}, 54 \mathrm{M} \\
\text { Mean age = } 13.7 \text { (sd 1.4) } \\
\text { Source = School } \\
\text { Diagnosis = Headache (at least weekly) } \\
\text { Mean years of pain = None given }\end{array}$} \\
\hline Interventions & \multicolumn{2}{|c|}{$\begin{array}{l}\text { "Progressive relaxation training" } \\
\text { "Placebo physical concentration training" }\end{array}$} \\
\hline Outcomes & \multicolumn{2}{|c|}{$\begin{array}{l}\text { Primary Pain Outcome: Headache intensity } \\
\text { Primary Disability Outcome: School problems } \\
\text { Primary Mood Outcome: Anxiety (Fear of Failure) } \\
\text { 1. Headache intensity } \\
\text { 2. Headache frequency } \\
\text { 3. Headache duration } \\
\text { 4. School problems (composite) } \\
\text { 5. Fear of failure (from Hermans Debilitating Anxiety of Achievement Motivation Test) }\end{array}$} \\
\hline Notes & \multicolumn{2}{|l|}{$\begin{array}{l}\text { Original Study } \\
\text { Total Quality }=15 / 35 \\
\text { Treatment Quality = 5/9 } \\
\text { Design Quality }=10 / 26\end{array}$} \\
\hline \multicolumn{3}{|l|}{ Risk of bias } \\
\hline Bias & Authors' judgement & Support for judgement \\
\hline $\begin{array}{l}\text { Random sequence generation (selection } \\
\text { bias) }\end{array}$ & Unclear risk & $\begin{array}{l}\text { 'The } 19 \text { classes of the participating teach- } \\
\text { ers were allocated at random to a Progres- } \\
\text { sive Relaxation Training or a Placebo Train- } \\
\text { ing group.' Comment: Probably done, no } \\
\text { method described }\end{array}$ \\
\hline Allocation concealment (selection bias) & Unclear risk & $\begin{array}{l}\text { No description found in text. Comment: } \\
\text { Probably not done. }\end{array}$ \\
\hline $\begin{array}{l}\text { Blinding of outcome assessment (detection } \\
\text { bias) } \\
\text { All outcomes }\end{array}$ & Unclear risk & $\begin{array}{l}\text { No description found in text. Comment: } \\
\text { Probably not done. }\end{array}$ \\
\hline $\begin{array}{l}\text { Incomplete outcome data (attrition bias) } \\
\text { All outcomes }\end{array}$ & Low risk & No dropouts were reported. \\
\hline Selective reporting (reporting bias) & High risk & Data were incompletely reported. \\
\hline
\end{tabular}


Richter 1986

\begin{tabular}{|c|c|c|}
\hline Methods & \multicolumn{2}{|c|}{ RCT. Three arms. Assessed at pre-treatment, posttreatment } \\
\hline Participants & \multicolumn{2}{|c|}{$\begin{array}{l}\text { End of treatment } n=43 \\
\text { Start of Treatment } n=51 \\
\text { Sex: } 34 F, 17 M \\
\text { Mean age }=12.9 \\
\text { Source = Referred by physicians to children's hospital } \\
\text { Diagnosis = Migraine } \\
\text { Mean years of pain = Not given: most over two years }\end{array}$} \\
\hline Interventions & \multicolumn{2}{|l|}{$\begin{array}{l}\text { "Relaxation training" } \\
\text { "Cognitive coping" } \\
\text { "Attention control" }\end{array}$} \\
\hline Outcomes & \multicolumn{2}{|c|}{$\begin{array}{l}\text { Primary Pain Outcome: Headache diary } \\
\text { Primary Disability Outcome: None } \\
\text { Primary Mood Outcome: Child Depression rating scale } \\
\text { 1. Headache index (intensity, frequency, duration, medication taken: diary) } \\
\text { 2. State Trait Anxiety Inventory (STAI) or State-Trait Anxiety Inventory for Children } \\
\text { (STAI-C) } \\
\text { 3. Children's Depression Rating Scale }\end{array}$} \\
\hline Notes & \multicolumn{2}{|l|}{$\begin{array}{l}\text { Original Study } \\
\text { Total Quality = 20/35 } \\
\text { Treatment Quality }=6 / 9 \\
\text { Design Quality = } 14 / 26\end{array}$} \\
\hline \multicolumn{3}{|l|}{ Risk of bias } \\
\hline Bias & Authors' judgement & Support for judgement \\
\hline $\begin{array}{l}\text { Random sequence generation (selection } \\
\text { bias) }\end{array}$ & Unclear risk & $\begin{array}{l}\text { 'And randomly assigned to treatment'. } \\
\text { Comment: Probably done, no method de- } \\
\text { scribed }\end{array}$ \\
\hline Allocation concealment (selection bias) & Unclear risk & $\begin{array}{l}\text { No description found in text. Comment: } \\
\text { Probably not done. }\end{array}$ \\
\hline $\begin{array}{l}\text { Blinding of outcome assessment (detection } \\
\text { bias) } \\
\text { All outcomes }\end{array}$ & Unclear risk & $\begin{array}{l}\text { No description found in text. Comment: } \\
\text { Probably not done. }\end{array}$ \\
\hline $\begin{array}{l}\text { Incomplete outcome data (attrition bias) } \\
\text { All outcomes }\end{array}$ & Low risk & $\begin{array}{l}\text { 'Over the course of treatment there were } \\
8 \text { drop-outs. A chi-square analysis compar- } \\
\text { ing attrition rates across interventions was } \\
\text { not significant.' Comment: Attrition ade- } \\
\text { quately reported and no significant differ- } \\
\text { ences between completers and non-com- } \\
\text { pleters reported }\end{array}$ \\
\hline Selective reporting (reporting bias) & High risk & Data were incompletely reported. \\
\hline
\end{tabular}

Robins 2005 
Robins 2005

Methods

RCT. Two arms. Assessed at pre-treatment, post-treatment (three months after start), six to twelve months

\begin{tabular}{|c|c|c|}
\hline & \multicolumn{2}{|l|}{ to twelve months } \\
\hline Participants & \multicolumn{2}{|c|}{$\begin{array}{l}\text { End of treatment } \mathrm{n}=69 \\
\text { Start of treatment } \mathrm{n}=86 \\
\text { Sex: } 39 \mathrm{~F}, 30 \mathrm{M} \\
\text { Mean age = } 11.4(\mathrm{sd} 2.4) \\
\text { Source = Paediatric gastroenterology outpatient clinic of children's hospital } \\
\text { Diagnosis = Recurrent abdominal pain } \\
\text { Mean years of pain = Not stated }\end{array}$} \\
\hline Interventions & \multicolumn{2}{|c|}{$\begin{array}{l}\text { "Short term cognitive behavioural family treatment plus standard medical care" } \\
\text { "Standard medical care" }\end{array}$} \\
\hline Outcomes & \multicolumn{2}{|c|}{$\begin{array}{l}\text { Primary Pain Outcome: Abdominal Pain Index } \\
\text { Primary Disability Outcome: Functional Disability Inventory } \\
\text { Primary Mood Outcome: none } \\
\text { 1. Abdominal Pain Index } \\
\text { 2. Child Somatization Inventory } \\
\text { 3. Functional Disability Inventory } \\
\text { 4. Abdominal Pain Index (parent) } \\
\text { 5. Child Somatization Inventory (parent) }\end{array}$} \\
\hline Notes & \multicolumn{2}{|l|}{$\begin{array}{l}\text { Updated Study } 2009 \\
\text { Total Quality = 27/35 } \\
\text { Treatment Quality = 7/9 } \\
\text { Design Quality = 20/26 }\end{array}$} \\
\hline \multicolumn{3}{|l|}{ Risk of bias } \\
\hline Bias & Authors' judgement & Support for judgement \\
\hline $\begin{array}{l}\text { Random sequence generation (selection } \\
\text { bias) }\end{array}$ & Low risk & $\begin{array}{l}\text { 'The remaining sample of } 86 \text { were ran- } \\
\text { domly assigned using a coin-flip method.' } \\
\text { Comment: Probably done }\end{array}$ \\
\hline Allocation concealment (selection bias) & Unclear risk & $\begin{array}{l}\text { No description found in text. Comment: } \\
\text { Probably not done. }\end{array}$ \\
\hline $\begin{array}{l}\text { Blinding of outcome assessment (detection } \\
\text { bias) } \\
\text { All outcomes }\end{array}$ & Unclear risk & $\begin{array}{l}\text { No description found in text. Comment: } \\
\text { Probably not done. }\end{array}$ \\
\hline $\begin{array}{l}\text { Incomplete outcome data (attrition bias) } \\
\text { All outcomes }\end{array}$ & Unclear risk & $\begin{array}{l}\text { Attrition is described, however significant } \\
\text { differences between completers and non- } \\
\text { completers were not described }\end{array}$ \\
\hline Selective reporting (reporting bias) & High risk & Data were incompletely reported. \\
\hline
\end{tabular}

Sanders 1994

\begin{tabular}{l|l}
\hline Methods & RCT. Two arms. Assessed at pre-treatment, post-treatment, six months, one year \\
\hline
\end{tabular}




\begin{tabular}{|c|c|c|}
\hline \multicolumn{3}{|l|}{ Sanders 1994} \\
\hline Participants & \multicolumn{2}{|c|}{$\begin{array}{l}\text { End of treatment } \mathrm{n}=44 \\
\text { Start of Treatment } \mathrm{n}=44 \\
\text { Sex: } 28 \mathrm{~F}, 16 \mathrm{M} \\
\text { Mean age }=9.2(\mathrm{sd} 1.9) \\
\text { Source }=\text { Not given } \\
\text { Diagnosis = Recurrent abdominal pain } \\
\text { Mean years of pain }=3.7\end{array}$} \\
\hline Interventions & \multicolumn{2}{|c|}{$\begin{array}{l}\text { "Cognitive behaviour therapy" } \\
\text { "Standard paediatric care" }\end{array}$} \\
\hline Outcomes & \multicolumn{2}{|c|}{$\begin{array}{l}\text { Primary Pain Outcome: pain diary } \\
\text { Primary Disability Outcome: Interference with child activity } \\
\text { Primary Mood Outcome: none } \\
\text { 1. Pain intensity diary } \\
\text { 2. Parent observation of child pain behaviour (POR) } \\
\text { 3. Child behaviour checklist (CBCL' '83) } \\
\text { 4. Relapse vs pain-free } \\
\text { 5. Interference with child activity (child report) } \\
\text { 6. Interference with child activity (parent report) }\end{array}$} \\
\hline Notes & \multicolumn{2}{|c|}{$\begin{array}{l}\text { Original Study } \\
\text { Total Quality = 19/35 } \\
\text { Treatment Quality = 4/9 } \\
\text { Design Quality = 15/26 }\end{array}$} \\
\hline \multicolumn{3}{|l|}{ Risk of bias } \\
\hline Bias & Authors' judgement & Support for judgement \\
\hline $\begin{array}{l}\text { Random sequence generation (selection } \\
\text { bias) }\end{array}$ & Unclear risk & $\begin{array}{l}\text { 'The study used a randomised group com- } \\
\text { parison design with two treatment condi- } \\
\text { tions.' Comment: method not described }\end{array}$ \\
\hline Allocation concealment (selection bias) & Unclear risk & $\begin{array}{l}\text { No description found in text. Comment: } \\
\text { Probably not done. }\end{array}$ \\
\hline $\begin{array}{l}\text { Blinding of outcome assessment (detection } \\
\text { bias) } \\
\text { All outcomes }\end{array}$ & Unclear risk & $\begin{array}{l}\text { No description found in text. Comment: } \\
\text { Probably not done. }\end{array}$ \\
\hline $\begin{array}{l}\text { Incomplete outcome data (attrition bias) } \\
\text { All outcomes }\end{array}$ & High risk & $\begin{array}{l}\text { Attrition was not described and significant } \\
\text { differences between completers and non- } \\
\text { completers were not reported }\end{array}$ \\
\hline Selective reporting (reporting bias) & High risk & Data were incompletely reported. \\
\hline
\end{tabular}

\section{Sartory 1998}

\begin{tabular}{l|l}
\hline Methods & $\begin{array}{l}\text { RCT. Three arms. Assessed at pre-treatment, post-treatment (four weeks after end of } \\
\text { intervention), eight months follow-up }\end{array}$ \\
\hline Participants & End of treatment $\mathrm{n}=43$
\end{tabular}




\section{Sartory 1998}

\begin{tabular}{|c|c|}
\hline & $\begin{array}{l}\text { Start of Treatment } \mathrm{n}=43 \\
\text { Sex: } 17 \mathrm{~F}, 26 \mathrm{M} \\
\text { Mean age }=11.3(\mathrm{sd} 2.1) \\
\text { source = Outpatient clinic of paediatric hospital and advertising in press } \\
\text { Diagnosis = Migraine } \\
\text { Mean years of pain }=4.6\end{array}$ \\
\hline Interventions & $\begin{array}{l}\text { "Cephalic vasomotor training + stress management" } \\
\text { "Relaxation training + stress management" } \\
\text { "Beta-blocker (metoprolol)" }\end{array}$ \\
\hline Outcomes & $\begin{array}{l}\text { Primary Pain Outcome: headache index } \\
\text { Primary Disability Outcome: none } \\
\text { Primary Mood Outcome: mood faces scale } \\
\text { 1. Headache index } \\
\text { 2. Episodes/week when analgesics taken } \\
\text { 3. Mood faces scale, 5-point smiling - upset }\end{array}$ \\
\hline Notes & $\begin{array}{l}\text { Updated Study } 2009 \\
\text { Total Quality = 19/35 } \\
\text { Treatment Quality = 6/9 } \\
\text { Design Quality = 13/26 }\end{array}$ \\
\hline
\end{tabular}

Risk of bias

\begin{tabular}{l|l|l}
\hline Bias & Authors' judgement & Support for judgement \\
\hline $\begin{array}{l}\text { Random sequence generation (selection } \\
\text { bias) }\end{array}$ & Unclear risk & $\begin{array}{l}\text { 'Children were allocated randomly to one } \\
\text { of three treatment groups'. Comment: } \\
\text { Probably done, no method described }\end{array}$ \\
\hline $\begin{array}{l}\text { Allocation concealment (selection bias) } \\
\text { Blinding of outcome assessment (detection } \\
\text { bias) }\end{array}$ & Unclearcomes & $\begin{array}{l}\text { No description found in text. Comment: } \\
\text { Probably not done. }\end{array}$ \\
\hline $\begin{array}{l}\text { Incomplete outcome data (attrition bias) } \\
\text { All outcomes }\end{array}$ & Unclear risk & $\begin{array}{l}\text { No description found in text. Comment: } \\
\text { Probably not done. }\end{array}$ \\
\hline Selective reporting (reporting bias) & Low risk & $\begin{array}{l}\text { Attrition is described, however significant } \\
\text { differences between completers and non- } \\
\text { completers were not described }\end{array}$ \\
\hline
\end{tabular}

\section{Scharff 2002}

\begin{tabular}{l|l}
\hline Methods & $\begin{array}{l}\text { RCT. Three arms. Assessed at pre-treatment, post-treatment, three months, six months, } \\
\text { twelve months }\end{array}$ \\
\hline Participants & $\begin{array}{l}\text { End of treatment } \mathrm{n}=34 \\
\text { Start of Treatment } \mathrm{n}=36 \\
\text { Sex: 24F, 12M } \\
\text { Mean age } 12.8(\operatorname{sd} 2.4)\end{array}$
\end{tabular}




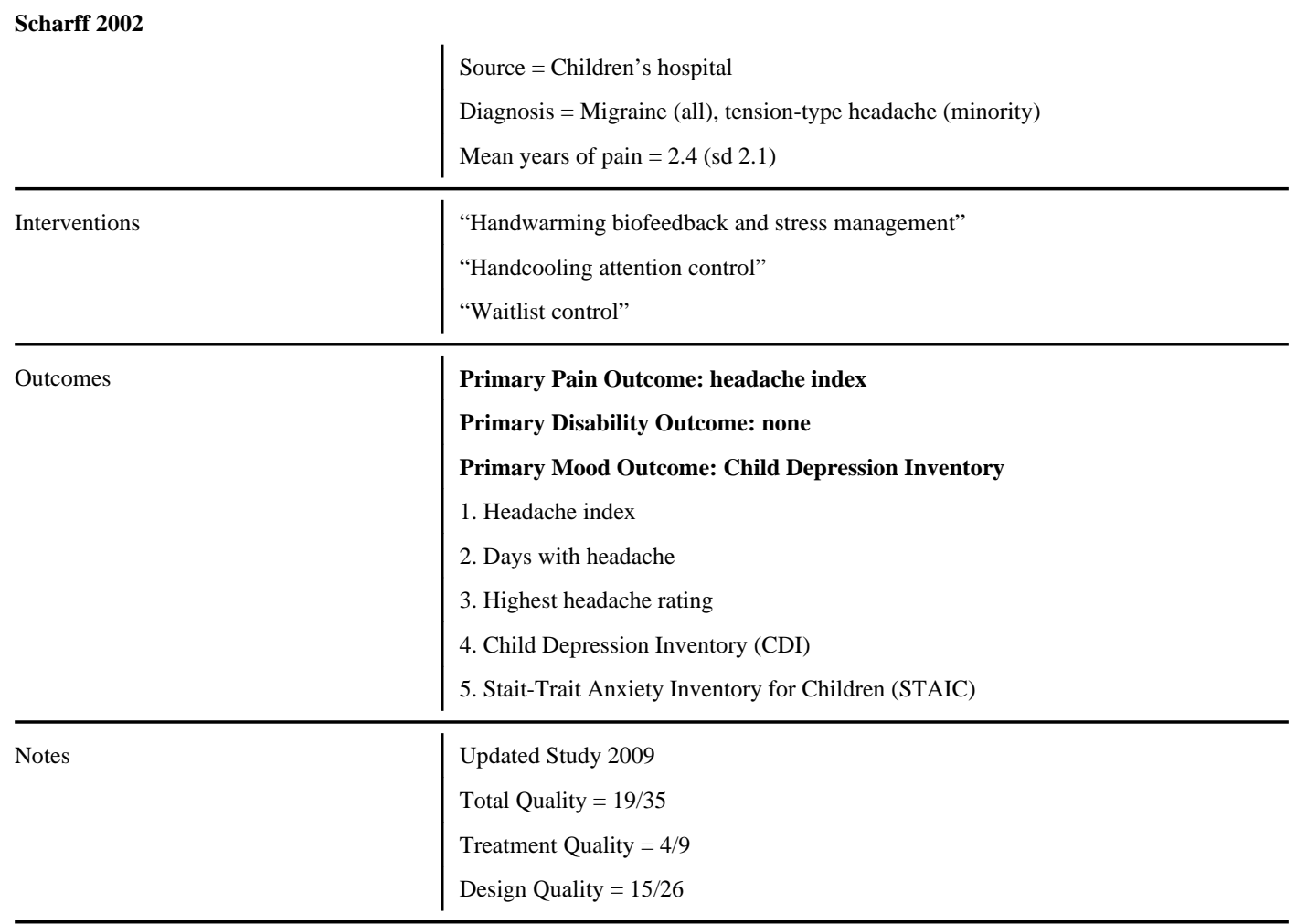

Risk of bias

\begin{tabular}{|c|c|c|}
\hline Bias & Authors' judgement & Support for judgement \\
\hline $\begin{array}{l}\text { Random sequence generation (selection } \\
\text { bias) }\end{array}$ & Low risk & $\begin{array}{l}\text { 'At the assessment visit children were ran- } \\
\text { domised into three groups using a ran- } \\
\text { domisation table'. Comment: probably } \\
\text { done }\end{array}$ \\
\hline Allocation concealment (selection bias) & Unclear risk & $\begin{array}{l}\text { No description found in text. Comment: } \\
\text { Probably not done. }\end{array}$ \\
\hline $\begin{array}{l}\text { Blinding of outcome assessment (detection } \\
\text { bias) } \\
\text { All outcomes }\end{array}$ & Unclear risk & $\begin{array}{l}\text { No description found in text. Comment: } \\
\text { Probably not done. }\end{array}$ \\
\hline $\begin{array}{l}\text { Incomplete outcome data (attrition bias) } \\
\text { All outcomes }\end{array}$ & Low risk & $\begin{array}{l}\text { Attrition is described, there were no signif- } \\
\text { icant differences between completers and } \\
\text { non-completers }\end{array}$ \\
\hline Selective reporting (reporting bias) & High risk & Data were incompletely reported. \\
\hline
\end{tabular}

\section{Stinson 2010}

\begin{tabular}{l|l}
\hline Methods & RCT. Two arms. Assessed at pre-treatment and post-treatment \\
\hline Participants & $\begin{array}{l}\text { End of treatment } \mathrm{n}=39 \\
\text { Start of treatment } \mathrm{n}=46 \\
\text { Sex: 31F, 15M } \\
\text { Mean age }=14.6 \text { (sd 1.5) } \\
\text { Source }=\text { Four paediatric tertiary care centres }\end{array}$
\end{tabular}


Stinson 2010

\begin{tabular}{l|l} 
& $\begin{array}{l}\text { Diagnosis = Juvenile Idiopathic Arthritis } \\
\text { Mean years of pain =6.4 (sd 4.6) }\end{array}$ \\
\hline Interventions & $\begin{array}{l}\text { "Internet treatment" } \\
\text { "Attentional control group" }\end{array}$ \\
\hline Outcomes & $\begin{array}{l}\text { Primary Pain Outcome: Recall Pain Inventory } \\
\text { Primary Disability Outcome: Juvenile Arthritis Quality of Life Questionnaire } \\
\text { Primary Mood Outcome: Perceived Severity of Stress Questionnaire } \\
\text { 1. Recall Pain Inventory } \\
\text { 2. Juvenile Arthritis Quality of Life Questionnaire } \\
\text { 3. Perceived Severity of Stress Questionnaire } \\
\text { 4. Medical Issues, Exercise, Pain and Social Support Questionnaire } \\
\text { 5. Children's Arthritis Self-Efficacy scale } \\
\text { 6. JIA-specific Child Adherence Report Questionnaire } \\
\text { 7. Parent Adherence Report Questionnaire }\end{array}$ \\
\hline Notes & $\begin{array}{l}\text { Updated study 2012 } \\
\text { Total Quality = 30/35 } \\
\text { Treatment Quality = 9/9 } \\
\text { Design Quality = 21/26 }\end{array}$ \\
\hline
\end{tabular}

Risk of bias

\begin{tabular}{|c|c|c|}
\hline Bias & Authors' judgement & Support for judgement \\
\hline $\begin{array}{l}\text { Random sequence generation (selection } \\
\text { bias) }\end{array}$ & Low risk & $\begin{array}{l}\text { 'A fixed allocation randomisation scheme } \\
\text { was used. Specificallly, blocked randomi- } \\
\text { sation was employed. An online random } \\
\text { number generator was used to produce } \\
\text { the blocked randomisation. Group assign- } \\
\text { ments were identified by ID number in } \\
\text { sealed envelopes during the recruitment pe- } \\
\text { riod.' Comment: Probably done }\end{array}$ \\
\hline Allocation concealment (selection bias) & Low risk & $\begin{array}{l}\text { 'A fixed allocation randomisation scheme } \\
\text { was used. Specificallly, blocked randomi- } \\
\text { sation was employed. An online random } \\
\text { number generator was used to produce } \\
\text { the blocked randomisation. Group assign- } \\
\text { ments were identified by ID number in } \\
\text { sealed envelopes during the recruitment pe- } \\
\text { riod.' Comment: Probably done }\end{array}$ \\
\hline $\begin{array}{l}\text { Blinding of outcome assessment (detection } \\
\text { bias) } \\
\text { All outcomes }\end{array}$ & Unclear risk & $\begin{array}{l}\text { No description found in text. Comment: } \\
\text { Probably not done. }\end{array}$ \\
\hline $\begin{array}{l}\text { Incomplete outcome data (attrition bias) } \\
\text { All outcomes }\end{array}$ & Unclear risk & $\begin{array}{l}\text { Attrition is reported. However, significant } \\
\text { differences between completers and non- } \\
\text { completers were not reported }\end{array}$ \\
\hline Selective reporting (reporting bias) & Low risk & Data were fully reported. \\
\hline
\end{tabular}

Trautmann 2010 
Trautmann 2010

\begin{tabular}{|c|c|}
\hline Participants & $\begin{array}{l}\text { End of treatment } n=55 \text {, Follow-up } n=40 \\
\text { Start of treatment } n=68 \\
\text { Sex: } 36 F, 30 M \\
\text { Mean age }=12.7(\mathrm{sd} 2.2) \\
\text { Source = Newspaper adverts and websites } \\
\text { Diagnosis = Headache (migraine, tension type headache or combined headache) } \\
\text { Mean years of pain }=2.8(\operatorname{sd} 3.0)\end{array}$ \\
\hline Interventions & $\begin{array}{l}\text { "Cognitive behavioural therapy, self-help and management" } \\
\text { "Applied relaxation group" } \\
\text { "Education" }\end{array}$ \\
\hline Outcomes & $\begin{array}{l}\text { Primary Pain Outcome: Pain Diary } \\
\text { Primary Disability Outcome: none } \\
\text { Primary Mood Outcome: Children's Depression Inventory } \\
\text { 1. Pain diary } \\
\text { 2. Children's depression inventory } \\
\text { 3. Pain Catastrophising scale } \\
\text { 4. Health-related quality of life (KINDL-R) } \\
\text { 5. Strength and difficulties questionnaire }\end{array}$ \\
\hline Notes & $\begin{array}{l}\text { Updated study } 2012 \\
\text { Total Quality = 29/35 } \\
\text { Treatment Quality = 8/9 } \\
\text { Design Quality = 21/26 }\end{array}$ \\
\hline
\end{tabular}

Risk of bias

\begin{tabular}{|c|c|c|}
\hline Bias & Authors' judgement & Support for judgement \\
\hline $\begin{array}{l}\text { Random sequence generation (selection } \\
\text { bias) }\end{array}$ & Low risk & $\begin{array}{l}\text { 'All participants were randomly assigned to } \\
\text { one of the three conditions. The randomly } \\
\text { ordered list of groups was used to assign se- } \\
\text { quentially enrolled participants to two in- } \\
\text { tervention groups and the active control } \\
\text { condition.' Comment: Probably done }\end{array}$ \\
\hline Allocation concealment (selection bias) & Low risk & $\begin{array}{l}\text { 'The first author randomly selected par- } \\
\text { ticipants according to a computer-gener- } \\
\text { ated randomisation list by using the 'select } \\
\text { cases' random selection option.' Comment: } \\
\text { Probably done }\end{array}$ \\
\hline $\begin{array}{l}\text { Blinding of outcome assessment (detection } \\
\text { bias) } \\
\text { All outcomes }\end{array}$ & Unclear risk & $\begin{array}{l}\text { No description found in text. Comment: } \\
\text { Probably not done. }\end{array}$ \\
\hline $\begin{array}{l}\text { Incomplete outcome data (attrition bias) } \\
\text { All outcomes }\end{array}$ & Low risk & $\begin{array}{l}\text { Attrition is described. 'Furthermore, no sig- } \\
\text { nificant differences were found between } \\
\text { dropouts and completers' }\end{array}$ \\
\hline Selective reporting (reporting bias) & Low risk & Data were fully extracted. \\
\hline
\end{tabular}


van Tilburg 2009

\begin{tabular}{|c|c|}
\hline Methods & RCT. Two arms. Assessed at pre-treatment, post-treatment,six months \\
\hline Participants & $\begin{array}{l}\text { End of treatment } n=29 \text {, Follow-up } n=24 \\
\text { Start of treatment } n=34 \\
\text { Sex: } 25 F, 9 M \\
\text { Mean age }=10.25 \text { (sd } 2.6 \text { ) } \\
\text { Source = Univeristy of North Carolina and Duke University Medical Centres } \\
\text { Diagnosis = Functional abdominal pain } \\
\text { Mean years of pain = unknown }\end{array}$ \\
\hline Interventions & $\begin{array}{l}\text { "Guided imagery treatment" } \\
\text { "Standard medical care" }\end{array}$ \\
\hline Outcomes & $\begin{array}{l}\text { Primary Pain Outcome: Abdominal Pain Index } \\
\text { Primary Disability Outcome: Functional Disability Inventory } \\
\text { Primary Mood Outcome: none } \\
\text { 1. Abdominal pain index } \\
\text { 2. Functional disability inventory } \\
\text { 3. School attendance } \\
\text { 4. Pediatric quality of life inventory } \\
\text { 5. Global rating of change in abdominal pain } \\
\text { 6. Treatment compliance } \\
\text { 7. Questionnaire of paediatric gastrointestinal symptoms } \\
\text { 8. Health care utilisation }\end{array}$ \\
\hline Notes & $\begin{array}{l}\text { Updated study } 2012 \\
\text { Total Quality = 21/35 } \\
\text { Treatment Quality = 8/9 } \\
\text { Design Quality = 13/26 }\end{array}$ \\
\hline
\end{tabular}

Risk of bias

\begin{tabular}{|c|c|c|}
\hline Bias & Authors' judgement & Support for judgement \\
\hline $\begin{array}{l}\text { Random sequence generation (selection } \\
\text { bias) }\end{array}$ & Unclear risk & $\begin{array}{l}\text { 'Thirty-four children, were assigned ran- } \\
\text { domly to receive } 2 \text { months of standard } \\
\text { medical care with or without home-based, } \\
\text { guided imagery treatment.' Comment: } \\
\text { Probably done, method not described }\end{array}$ \\
\hline Allocation concealment (selection bias) & Low risk & $\begin{array}{l}\text { 'Children picked a closed envelope that de- } \\
\text { termined whether they would receive stan- } \\
\text { dard medical care with or without guided } \\
\text { imagery treatment.' Comment: Probably } \\
\text { done }\end{array}$ \\
\hline $\begin{array}{l}\text { Blinding of outcome assessment (detection } \\
\text { bias) } \\
\text { All outcomes }\end{array}$ & Unclear risk & $\begin{array}{l}\text { No description found in text. Comment: } \\
\text { Probably not done. }\end{array}$ \\
\hline $\begin{array}{l}\text { Incomplete outcome data (attrition bias) } \\
\text { All outcomes }\end{array}$ & Unclear risk & $\begin{array}{l}\text { Attrition is described, however significant } \\
\text { differences between completers and non- } \\
\text { completers are not reported }\end{array}$ \\
\hline
\end{tabular}


van Tilburg 2009

\begin{tabular}{l|l|l}
\hline Selective reporting (reporting bias) & Low risk & Data were fully reported. \\
\hline
\end{tabular}

Vlieger 2007

\begin{tabular}{|c|c|c|}
\hline Methods & \multicolumn{2}{|c|}{ RCT. Two arms. Assessed at pre-treatment, post-treatment, six months, one year } \\
\hline Participants & \multicolumn{2}{|c|}{$\begin{array}{l}\text { End of treatment } \mathrm{n}=51 \\
\text { Start of Treatment } \mathrm{n}=52 \\
\text { Sex: } 39 \mathrm{~F}, 13 \mathrm{M} \\
\text { Mean age }=13.3(\mathrm{sd} 2.7) \\
\text { Source = Paediatric gastroenterology dept in hospital } \\
\text { Diagnosis = Functional abdominal pain }(\mathrm{N}=31) \text { and irritable bowel syndrome (IBS) } \\
(\mathrm{N}=22) \\
\text { Mean years of pain }=3.4\end{array}$} \\
\hline Interventions & \multicolumn{2}{|c|}{$\begin{array}{l}\text { "Gut-directed hypnotherapy" } \\
\text { "Standard medical care plus supportive therapy" }\end{array}$} \\
\hline Outcomes & \multicolumn{2}{|c|}{$\begin{array}{l}\text { Primary Pain Outcome: weekly pain intensity } \\
\text { Primary Disability Outcome: none } \\
\text { Primary Mood Outcome: none } \\
\text { 1. Total pain intensity over } 1 \text { week (9-point faces affective pain intensity scale, reduced } \\
\text { to } 0-3 \text { points hence } 0-21 \text { ) } \\
\text { 2. Total pain frequency over } 1 \text { week (frequency reduced to } 0-3 \text { scale per day) } \\
\text { 3. Associated symptoms (nausea, vomiting, loss of appetite, flatus, nocturnal pain, pain } \\
\text { on wakening, pain related to meals) }\end{array}$} \\
\hline Notes & \multicolumn{2}{|l|}{$\begin{array}{l}\text { Updated Study } 2009 \\
\text { Total Quality = 24/35 } \\
\text { Treatment Quality = 6/9 } \\
\text { Design Quality }=18 / 26\end{array}$} \\
\hline \multicolumn{3}{|l|}{ Risk of bias } \\
\hline Bias & Authors' judgement & Support for judgement \\
\hline $\begin{array}{l}\text { Random sequence generation (selection } \\
\text { bias) }\end{array}$ & Low risk & $\begin{array}{l}\text { 'Patients were randomly allocated using } \\
\text { a computerised random-number generator } \\
\text { for concealment to either HT or standard } \\
\text { medical care.' Comment: Probably done }\end{array}$ \\
\hline Allocation concealment (selection bias) & Low risk & $\begin{array}{l}\text { 'Patients were randomly allocated using } \\
\text { a computerised random-number generator } \\
\text { for concealment to either HT or standard } \\
\text { medical care.' Comment: Probably done }\end{array}$ \\
\hline $\begin{array}{l}\text { Blinding of outcome assessment (detection } \\
\text { bias) } \\
\text { All outcomes }\end{array}$ & Low risk & $\begin{array}{l}\text { 'Pain diaries were analysed by S. W. (medi- } \\
\text { cal student), who was blinded to the treat- } \\
\text { ment arm.' Comment: Probably done }\end{array}$ \\
\hline $\begin{array}{l}\text { Incomplete outcome data (attrition bias) } \\
\text { All outcomes }\end{array}$ & Unclear risk & $\begin{array}{l}\text { Attrition is described, however significant } \\
\text { differences between completers and non- } \\
\text { completers are not reported }\end{array}$ \\
\hline Selective reporting (reporting bias) & Low risk & Data were fully reported. \\
\hline
\end{tabular}


Wicksell 2009

\begin{tabular}{|c|c|}
\hline Methods & RCT. Two arms. Assessed at pre-treatment, post-treatment, 3.5 months, 6.8 months \\
\hline Participants & $\begin{array}{l}\text { End of treatment } n=29 \text {, Follow-up } 3.5 \text { months } n=24 \text {, Follow-up } 6.8 \text { months }=24 \\
\text { Start of treatment } n=32 \\
\text { Sex: } 25 F, 7 M \\
\text { Mean age = } 14.8 \text { (sd 2.4) } \\
\text { Source = Astrid Lindgren Children's Hospital, Karolinska University Hospital } \\
\text { Diagnosis = Mixed pain (headache, back/neck, widespread musculoskeletal, complex } \\
\text { regional pain syndrome, visceral, lower extremities, postherpetic type cheek pain } \\
\text { Mean years of pain }=2.7\end{array}$ \\
\hline Interventions & $\begin{array}{l}\text { "Exposure and acceptance" } \\
\text { "Mulitdiciplinary treatment and amitriptyline" }\end{array}$ \\
\hline Outcomes & $\begin{array}{l}\text { Primary Pain Outcome: Pain Intensity } \\
\text { Primary Disability Outcome: Functional Disability Inventory } \\
\text { Primary Mood Outcome: Center for Epidemiological Studies Depression Scale for } \\
\text { Children } \\
\text { 1. Pain intensity } \\
\text { 2. Functional disability inventory } \\
\text { 3. Center for Epidemiological Studies Depression Scale for Children } \\
\text { 4. Multidimensional Pain Inventory (interference scale) } \\
\text { 5. Brief pain inventory (pain interference items) } \\
\text { 6. Pain and impairment relationship scale } \\
\text { 7. Short form-36 health survey } \\
\text { 8. Tampa scale of Kinesiophobia } \\
\text { 9. Pain coping questionnaire (internalising and catastrophising) } \\
\text { 10. } 5 \text { author-generated questions on pain-related discomfort }\end{array}$ \\
\hline Notes & $\begin{array}{l}\text { Updated study } 2012 \\
\text { Total Quality = 20/35 } \\
\text { Treatment Quality = 6/9 } \\
\text { Design Quality = 14/26 }\end{array}$ \\
\hline
\end{tabular}

Risk of bias

\begin{tabular}{l|l|l}
\hline Bias & Authors' judgement & Support for judgement \\
\hline $\begin{array}{l}\text { Random sequence generation (selection } \\
\text { bias) }\end{array}$ & Low risk & $\begin{array}{l}\text { 'A total of 32 participants were included in } \\
\text { the study and randomised to one of the two } \\
\text { treatment conditions. A simple randomisa- } \\
\text { tion technique was used.' Comment: Prob- } \\
\text { ably done }\end{array}$ \\
\begin{tabular}{l|ll} 
Allocation concealment (selection bias) \\
$\begin{array}{l}\text { Blinding of outcome assessment (detection } \\
\text { bias) }\end{array}$
\end{tabular} & Low risk & $\begin{array}{l}\text { 'A sealed envelope (prepared by a secretary } \\
\text { blind to the objective of the study) contain- } \\
\text { ing a code for 'exposure and acceptance' or } \\
\text { 'MDT' was opened, assigning the partici- } \\
\text { pant to one of the treatment conditions.' } \\
\text { Comment: probably done }\end{array}$ \\
\hline
\end{tabular}


Wicksell 2009

\begin{tabular}{|c|c|c|}
\hline All outcomes & & $\begin{array}{l}\text { treatment protocol.' Comment: Probably } \\
\text { done }\end{array}$ \\
\hline $\begin{array}{l}\text { Incomplete outcome data (attrition bias) } \\
\text { All outcomes }\end{array}$ & Unclear risk & $\begin{array}{l}\text { Attrition is described, however significant } \\
\text { differences between completers and non- } \\
\text { completers are not reported }\end{array}$ \\
\hline Selective reporting (reporting bias) & Low risk & Data are fully reported. \\
\hline
\end{tabular}

CBT: Cognitive behavioural therapy

FDI-C: Functional Disability Inventory-Children

JPFM: Juvenile Primary Fibromyalgia

NRS: Numeric rating scale

PEDSQL:Paediatric Scale Quality of Life Inventory

RCT: Randomised controlled trial

SCD: Sickle cell disease

VAS: Visual analogue scale 
Characteristics of excluded studies [ordered by study ID]

\begin{tabular}{l|l}
\hline Study & Reason for exclusion \\
\hline Fentress 1986 & Inadequate sample size ( $<10$ in one arm of study design) \\
\hline Kroener-Herwig 1998 & Inadequate sample size ( $\mathrm{n}<10$ in one arm of study design) \\
\hline Larsson 1986 & Inadequate sample size ( $\mathrm{n}<10$ in one arm of study design) \\
\hline Olness 1987 & Insufficient psychological treatment \\
\hline Sanders 1989 & Inadequate sample size ( $<<10$ in one arm of study design) \\
\hline Trautmann 2008 & Inadequate sample size ( $<<10$ in one arm of study design) \\
\hline Vlieger 2012 & Follow-up period more than one year \\
\hline Weydert 2006 & Inadequate sample size ( $<<10$ in one arm of study design) \\
\hline Youssef 2009 & Inadequate sample size ( $<<10$ in one arm of study design) \\
\hline
\end{tabular}

